DOE/AL/87310-3

\title{
A STUDY OF NOx REDUCTION BY FUEL INJECTION RECIRCULATION
}

Final Report

January 1995 - June 1996

James J. Feese and Stephen R. Turns

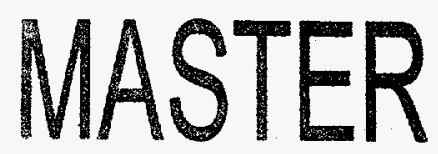

THE PENNSYLVANIA STATE UNIVERSTTY

University Park, PA 16802

\begin{abstract}
DIPTBSUTON OF THIS DOCUMENT IS UNLIMTED
Date Published - August 1996

PREPARED FOR THE UNITED STATES

DEPARTMENT OF ENERGY
\end{abstract}

Under Grant No. DE-FG04-95AL87310

DISCLAIMER

This report was prepared as an account of work sponsored by an agency of the United States Government. Neither the United States Government nor any agency thereof, nor any of their employees, makes any warranty, express or implied, or assumes any legal liability or responsibility for the accuracy, completeness, or usefulness of any information, apparatus, product, or process disclosed, or represents that its use would not infringe privately owned rights. Reference herein to any specific commercial product, process, or service by trade name, trademark, manufacturer, or otherwise does not necessarily constitute or imply its endorsement, recommendation, or favoring by the United States Government or any agency thereof. The views and opinions of authors expressed herein do not necessarily state or reflect those of the United States Government or any agency thereof. 


\section{DISCLADMER}

Portions of this document may be illegible in electronic image products. Images are produced from the best available original document. 


\section{EXECUTIVE SUMMARY}

Flue-gas recirculation (FGR) is a well-known method used to control oxides of nitrogen $\left(\mathrm{NO}_{\mathrm{X}}\right)$ in industrial burner applications. Recent small- and large-scale experiments in natural-gas fired boilers have shown that introducing the recirculated flue gases with the fuel results in a much greater reduction in $\mathrm{NO}_{\mathrm{x}}$, per unit mass of gas recirculated, in comparison to introducing the flue gases with the combustion air. That fuel injection recirculation (FIR) is more effective than windbox FGR is quite remarkable. At present, however, there is no definitive understanding of why FIR is more effective than conventional FGR. The objective of the present investigation is to ascertain whether or not chemical and/or molecular transport effects alone can explain the differences in $\mathrm{NO}_{\mathrm{X}}$ reduction observed between FIR and FGR by studying laminar diffusion flames. The purpose of studying laminar flames is to isolate chemical effects from the effects of turbulent mixing and heat transfer, which are inherent in practical boilers.

Numerical simulations of $\mathrm{H}_{2}$-air and $\mathrm{CH}_{4}$-air counterflow diffusion flames using full kinetics were performed and $\mathrm{NO}_{\mathrm{x}}$ emission indices calculated for various conditions. Studies were conducted in which a $\mathrm{N}_{2}$ diluent was added either on the fuel- or air-side of the flame for conditions of either fixed initial velocities or fixed fuel mass flux. Results from these simulation studies indicate that a major factor in diluent effectiveness is the differential effect on flame zone residence times associated with fuel-side verses air-side dilution. Simulations in which flow velocities were fixed as diluent was added either to the air or fuel stream showed lower $\mathrm{NO}_{\mathrm{X}}$ emissions for air-side dilution; however, if instead, fuel mass fluxes were fixed as diluent was added, which results in an increase in 
the velocity of the streams, fuel-side dilution was more effective. These results were independent of whether $\mathrm{H}_{2}$ or $\mathrm{CH}_{4}$ was used as the fuel.

Experiments using laminar jet flames were conducted in which either the air or fuel stream was diluted with $\mathrm{N}_{2}$. The experiments showed that fuel-side dilution results in somewhat greater $\mathrm{NO}_{\mathrm{x}}$ emission indices than air-side dilution. The higher flame temperatures measured with fuel dilution appear to be the principal cause of the higher emissions. Since fuel dilution is more effective than air dilution in suppressing in-flame soot formation, radiant heat losses with fuel dilution may be less, causing temperatures to be somewhat higher.

The results of both the numerical simulations and the experiments suggest that, although molecular transport and chemical kinetic phenomena are affected by the location of diluent addition depending on flow conditions, the greater effectiveness of FIR over FGR in practical applications may result from differences in turbulent mixing and heat transfer. Further research is required to understand how differences in diluent-addition location affect $\mathrm{NO}_{\mathrm{x}}$ production in turbulent flames. The present study, however, provides an underlying basis for understanding how flow conditions can affect flame chemistry. 


\section{TABLE OF CONTENTS}

LIST OF FIGURES.............................................................................. vi

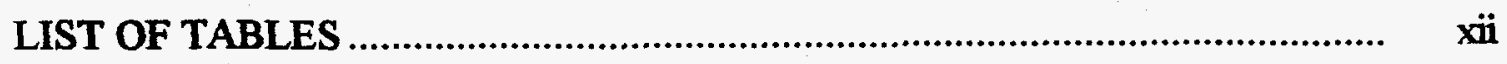

NOMENCLATURE .................................................................................... x xiii

Chapter 1 INTRODUCTION.................................................................. 1

1.1 Motivation ............................................................................... 1

1.2 Fundamentals of $\mathrm{NO}_{\mathrm{x}}$ Formation ......................................................... 4

1.2.1 NO $\mathrm{x}_{\mathrm{x}}$ Formation Mechanisms................................................ 6

1.2.2 Laminar Diffusion Flames ....................................................... 9

1.3 Objectives and Outline....................................................................... 13

Chapter 2 NUMERICAL METHOD ............................................................. 15

2.1 Model Description............................................................................... 15

2.1.1 Governing Equations and Solution..................................... 16

2.1.2 Chemical Kinetics ............................................................ 18

2.1.3 Emission Indices ................................................................ 19

2.1.4 Dilution Parameter, Z ...................................................... $\quad 20$

$2.2 \mathrm{H}_{2}$-Air Flame Simulation Results ....................................................... 21

$2.3 \mathrm{CH}_{4}$-Air Flame Simulation Results....................................................... 31

2.3.1 Nonreacting Isothermal Flow.............................................. 32

2.3.2 Reacting Flows ................................................................. 37

2.3.2.1 Flow and Flame Structure......................................... 40

2.3.2.2 NO Emission Index ............................................ 55

2.3.2.3 Parametric Studies................................................. 62

Chapter 3 EXPERIMENTAL METHOD....................................................... 69

3.1 Coannular Laminar Diffusion Flame Burner........................................ $\quad 69$ 
3.1.1 Coannular Bumer ......................................................... 69

3.1.2 Flow Metering and Heating System.................................. 71

3.1.3 Data Acquisition .............................................................. 73

3.1.4 Emission Indices ............................................................. 77

3.1.5 Experimental Test Conditions ...................................... 78

3.2 $\mathrm{CH}_{4}$-Air Experimental Flame Results......................................... 80

3.2.1 Temperature Measurements.......................................... 85

3.2.2 $\mathrm{NO}_{2}$ and $\mathrm{CO}$ Measurements ......................................... 94

3.2.3 Non-Sooting Diluted $\mathrm{CH}_{4}\left(\mathrm{~N}_{2}\right)$-Air Flames........................ 97

Chapter 4 SUMMARY AND CONCLUSIONS........................................ 101

4.1 Numerical Modeling ....................................................................... 101

4.2 Experiments ................................................................. 102

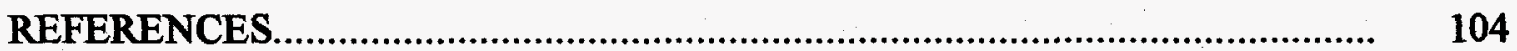

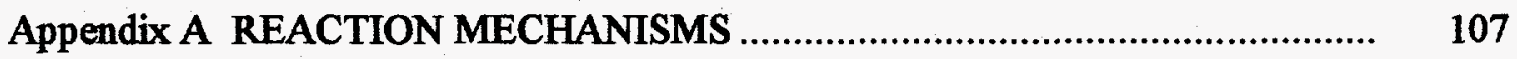

A.1 H $\mathrm{H}_{2}$-Air Chemical Kinetic Mechanism........................................... 107

A.2 Miller-Bowman ( $\mathrm{CH}_{4}$-Air) Chemical Kinetic Mechanism.................. 108

Appendix B TEMPERATURE CORRECTIONS...................................... 114

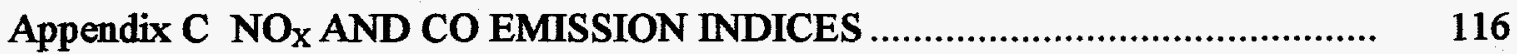




\section{LIST OF FIGURES}

FIGURE 1.1. Effect of flue gas recirculation on $\mathrm{NO}_{\mathrm{x}}$ emissions illustrating the greater effectiveness of introducing the flue gas with the fuel (FIR) versus mixing the flue gas with the air in the windbox (WB FGR). From reference [1].

FIGURE 1.2. Quantitative reaction path diagram for $\mathbf{C H}_{4}$-air, laminar, counterflow diffusion flame with an injection velocity of $u_{o}=5$ $\mathrm{cm} / \mathrm{s}$. From reference [9].

FIGURE 1.3. Calculated NO emission indices for $\mathrm{CH}_{4}$-air, laminar, counterflow diffusion flames showing contributions by various chemical routes. From reference [13]

FIGURE 2.1. Counterflow diffusion flame geometry showing location of flame and stagnation plane

FIGURE 2.2. Calculated effect of $\mathbf{N}_{2}$ dilution on $\mathrm{NO}$ emission indices of $\mathbf{H}_{2}$-air counterflow flames in which the $\mathrm{N}_{2}$ has been added to either the air or fuel streams $\left(u_{0}=u_{F, 0}=u_{O x, 0}=10 \mathrm{~cm} / \mathrm{s}\right)$.

FIGURE 2.3. Calculated effect of $\mathrm{N}_{2}$ dilution on $\mathrm{NO}$ emission indices of $\mathrm{H}_{2}$-air counterflow flames in which the $\mathrm{N}_{\mathbf{2}}$ has been added to either the air or fuel streams $\left(u_{0}=u_{F, o}=u_{O x, 0}=100 \mathrm{~cm} / \mathrm{s}\right)$.

FIGURE 2.4. Calculated temperature profiles through counterflow $\mathbf{H}_{2}$-air flames for $\mathrm{N}_{2}$ dihution of air (open symbols) or fuel (solid symbols). The dihuent fraction $Z$ is $0.4\left(u_{0}=u_{F, o}=u_{0 x, 0}=10\right.$ $\mathrm{cm} / \mathrm{s}$ )

FIGURE 2.5. Calculated major species profiles through counterflow $\mathbf{H}_{2}$-air flames for $\mathrm{N}_{2}$ dilution of air (open symbols) or fuel (solid symbols). The diluent fraction $Z$ is $0.4\left(u_{0}=u_{F, o}=u_{0 x, o}=10\right.$ $\mathrm{cm} / \mathrm{s})$

FIGURE 2.6. Calculated nitric oxide mole fraction profiles through counterflow $\mathrm{H}_{2}$-air flames for $\mathrm{N}_{2}$ dilution of air (open symbols) or fuel (solid symbols). The diluent fraction $\mathrm{Z}$ is $0.4\left(\mathrm{u}_{\mathrm{o}}=\mathrm{u}_{\mathrm{F}, \mathrm{o}}=\mathrm{u}_{\mathrm{Ox}, \mathrm{o}}=10\right.$ $\mathrm{cm} / \mathrm{s}$ ) 
FIGURE 2.7. Calculated nitric oxide molar production rates for counterflow $\mathrm{H}_{2}$-air flames for $\mathrm{N}_{2}$ dilution of air (open symbols) or fuel (solid symbols). The diluent fraction $Z$ is $0.4\left(u_{0}=u_{F, 0}=u_{O x, 0}=10\right.$ $\mathrm{cm} / \mathrm{s}$ )

FIGURE 2.8. Calculated $\mathrm{H}_{2}$ molar production rates for counterflow $\mathbf{H}_{2}$-air flames for $\mathrm{N}_{2}$ dilution of air (open symbols) or fuel (solid symbols). A negative production rate indicates fuel destruction. The diluent fraction $\mathrm{Z}$ is $0.4\left(\mathrm{u}_{\mathrm{o}}=\mathrm{u}_{\mathrm{F}, \mathrm{o}}=\mathrm{u}_{\mathrm{Ox}, \mathrm{o}}=10 \mathrm{~cm} / \mathrm{s}\right) \ldots \ldots \ldots \ldots$.

FIGURE 2.9. Mole fraction profiles for nonreacting ( $300 \mathrm{~K})$ counterflow. Pure $\mathrm{CH}_{4}$ flows from the left $(x=0)$ and $\mathrm{N}_{2}$-diluted air flows from the right $(x=L)$. The $N_{2}$-diluent fraction is $Z=0.15$ and $u_{0}=u_{L}=$ $50 \mathrm{~cm} / \mathrm{s}$.

FIGURE 2.10. Mole fraction profiles for nonreacting (300 K) counterflow. Diluted $\mathrm{CH}_{4}$ flows from the left $(x=0)$ and air flows from the right $(x=L)$. The $N_{2}$-diluent fraction is $Z=0.15$ and $u_{0}=u_{L}=$ $50 \mathrm{~cm} / \mathrm{s}$.

FIGURE 2.11. Velocity profiles for nonreacting counterflows corresponding to Figs. 2.8 and 2.9. The stagnation plane for the $\mathrm{N}_{2}$-dihuted $\mathrm{CH}_{4}$ case is shifted to the right because of the greater momentum flux associated with the $\mathrm{N}_{2}-\mathrm{CH}_{4}$ mixture compared to the undiluted $\mathrm{CH}_{4}$

FIGURE 2.12. $\mathrm{CH}_{4}$ mole fraction profiles from Figs. 2.8 and 2.9 plotted as functions of the distance from the stagnation plane. Also indicated is the stoichiometric $\mathrm{CH}_{4}$ mole fraction $(=0.0794)$ for these $\mathbf{N}_{2}$-diluted mixtures.

FIGURE 2.13. Velocity profiles for nonreacting counterflows with either the fuel or air stream diluted with $\mathrm{N}_{2}(Z=0.15)$ where the origin of the axial distance coordinate is the stagnation plane

FIGURE 2.14. Calculated effect of $\mathrm{N}_{2}$ dilution on $\mathrm{NO}$ emission indices of $\mathrm{CH}_{4}$ air counterflow flames in which the $\mathrm{N}_{2}$ has been added to either the air or fuel streams $\left(u_{0}=u_{F, o}=u_{0 x, 0}=5 \mathrm{~cm} / \mathrm{s}\right)$. Reactants enter at $300 \mathrm{~K}$

FIGURE 2.15. Calculated effect of $\mathrm{N}_{2}$ dilution on $\mathrm{NO}$ emission indices of $\mathrm{CH}_{4}$ air counterflow flames in which the $\mathrm{N}_{2}$ has been added to either the air or fuel streams $\left(u_{0}=u_{F, o}=u_{0 x, 0}=50 \mathrm{~cm} / \mathrm{s}\right)$. Reactants enter at $300 \mathrm{~K}$ 
FIGURE 2.16. Methane, oxygen, and nitrogen mole fraction profiles for undiluted counterflow diffusion flame (Case 1). Reactants enter at $300 \mathrm{~K}$ with velocities of $50 \mathrm{~cm} / \mathrm{s}$ at $x=0$ and $x=1.5 \mathrm{~cm}$.

FIGURE 2.17. Methane, oxygen, and nitrogen mole fraction profiles for a counterflow diffusion flame with the air stream diluted with $\mathbf{N}_{\mathbf{2}}(\mathrm{Z}$ $=0.15$ ) (Case 2). Reactants enter at $300 \mathrm{~K}$ with velocities of 50 $\mathrm{cm} / \mathrm{s}$ at $\mathrm{x}=0$ and $\mathrm{x}=1.5 \mathrm{~cm}$

FIGURE 2.18. Methane, oxygen, and nitrogen mole fraction profiles for a counterflow diffusion flame with the fuel stream diluted with $\mathbf{N}_{2}$ $(Z=0.15)$ (Case 3). Reactants enter at $300 \mathrm{~K}$ with velocities of $50 \mathrm{~cm} / \mathrm{s}$ at $\mathrm{x}=0$ and $\mathrm{x}=1.5 \mathrm{~cm}$

FIGURE 2.19. Methane, oxygen, and nitrogen mole fraction profiles for a counterflow diffusion flame with fuel dilution $(Z=0.15)$ (Case 4). The fuel mass flux is identical to the undiluted flame (Fig. 2.15) thus requiring the inlet velocities to be higher. Reactants enter at $300 \mathrm{~K}$ with velocities of $128 \mathrm{~cm} / \mathrm{s}$ at $\mathrm{x}=0$ and $\mathrm{x}=1.5 \mathrm{~cm}$

FIGURE 2.20. Temperature profiles for counterflow diffusion flames with no dilution (Case 1), the air stream diluted with $\mathrm{N}_{2}$ for $Z=0.15$ (Case 2), and the fuel stream diluted with $\mathrm{N}_{2}$ for $\mathrm{Z}=0.15$ (Case 3). Reactants enter at $300 \mathrm{~K}$ with velocities of $50 \mathrm{~cm} / \mathrm{s}$ at $x=0$ and $x=1.5 \mathrm{~cm}$.

FIGURE 2.21. Velocity profiles for counterflow diffusion flames with the air stream diluted with $\mathrm{N}_{2}$ for $Z=0.15$ (Case 2), and the fuel stream diluted with $\mathrm{N}_{2}$ for $Z=0.15$ (Case 3)

FIGURE 2.22. Temperature profile for counterflow diffusion flames with fuel stream diluted with $\mathrm{N}_{2}$ for $Z=0.15$ (Case 4). Reactants enter at $300 \mathrm{~K}$ with velocities of $128 \mathrm{~cm} / \mathrm{s}$ at $\mathrm{x}=0$ and $\mathrm{x}=1.5 \mathrm{~cm}$

FIGURE 2.23. Comparison of velocity profiles for the two cases where the fuel stream is diluted with $\mathrm{N}_{2}$ for $Z=0.15$

FIGURE 2.24. Nitric oxide emission indices for counterflow diffusion flames for selected conditions (cf. Table 2.2).

FIGURE 2.25. Nitric oxide mole fraction profiles for the three flame cases with $\mathrm{N}_{2}$-dilution with $\mathrm{Z}=0.15$ 
FIGURE 2.26. Nitric oxide volumetric production rates for the three flame cases with $\mathrm{N}_{2}$-dilution with $\mathrm{Z}=0.15$

FIGURE 2.27. Fuel $\left(\mathrm{CH}_{4}\right)$ volumetric production rates for the three flame cases with $\mathrm{N}_{2}$-dilution with $Z=0.15$

FIGURE 2.28. Calculated $\mathrm{NO}$ emission indices for counterflow $\mathrm{CH}_{4}$-air flames for $\mathrm{N}_{2}$ addition to either the air or fuel streams with reactants at $500 \mathrm{~K}$ (upper curves) and $300 \mathrm{~K}$ (lower curves). Fuel dilution is accomplished either with fixed nozzle exit velocities or fixed fuel mass flux

FIGURE 2.29. Calculated residence times above $1500 \mathrm{~K}$ for counterflow $\mathrm{CH}_{4}$-air flames for $\mathrm{N}_{2}$ addition to either the air or fuel streams with reactants at $500 \mathrm{~K}$ (upper curves) and $300 \mathrm{~K}$ (lower curves) ........

FIGURE 2.30. Calculated maximum temperature and $\mathbf{N}_{2}$ mole fraction at the location of maximum temperature as functions of $\mathrm{N}_{2}$ addition. Reactants enter at $300 \mathrm{~K}$.

FIGURE 2.31. Calculated maximum temperature and $\mathrm{N}_{2}$ mole fraction at the location of maximum temperature as functions of $\mathrm{N}_{2}$ addition. Reactants enter at $500 \mathrm{~K}$.

FIGURE 3.1. Laminar jet flame burner

FIGURE 3.2. Air, fuel, and $\mathrm{N}_{2}$ diluent flow control, metering, and heating schematic.

FIGURE 3.3. Gas sampling and analysis systems

FIGURE 3.4. Schematic of fine wire thermocouple showing the direction of motion used for acquiring radial temperature profiles.

FIGURE 3.5. $\mathrm{NO}_{\mathrm{x}}$ emission indices for laminar $\mathrm{CH}_{4}$ jet flames with various levels of $\mathrm{N}_{2}$ dilution in either the fuel or air stream. The fuel flowrate is held constant as the diluent is added.

FIGURE 3.6. Visible flame lengths for laminar jet flames with various levels of $\mathrm{N}_{2}$ dilution in either the fuel or air stream. Reactants enter at 293 $K$ with the fuel mass flowrate fixed at $3.0 \mathrm{mg} / \mathrm{s}$. 
FIGURE 3.7. Visible flame lengths for laminar $\mathrm{CH}_{4}$-air jet flames with various levels of $\mathrm{N}_{2}$ dilution in either the fuel or air stream. Reactants enter at $400 \mathrm{~K}$ (nominal) with the fuel mass flowrate fixed at 3.3 $\mathrm{mg} / \mathrm{s}$

FIGURE 3.8. Fraction of the visible flame length that is soot-free (blue) with various levels of $\mathrm{N}_{2}$ dilution in either the fuel or air stream. Reactants enter at $273 \mathrm{~K}$ with the fuel mass flowrate fixed at 3.0 $\mathrm{mg} / \mathrm{s}$

FIGURE 3.9. Fraction of the visible flame length that is soot-free (blue) with various levels of $\mathrm{N}_{2}$ dilution in either the fuel or air stream. Reactants enter at $400 \mathrm{~K}$ (nominal) with the fuel mass flowrate fixed at $3.3 \mathrm{mg} / \mathrm{s}$

FIGURE 3.10. Axial temperature profiles along the jet centerline for undiluted, fuel-diluted $(Z=0.15)$, and air-diluted $(Z=0.15)$ preheated $(400$ K) flames.

FIGURE 3.11. Radial temperature profiles for undiluted, fuel-diluted $(Z=0.15)$, and air-diluted $(Z=0.15)$ preheated (400 K nominal) flames at a height of $5 \mathrm{~mm}$ above the fuel jet exit.

FIGURE 3.12. Radial temperature profiles for undiluted, fuel-dihuted $(Z=0.15)$, and air-diluted $(Z=0.15)$ preheated $(400 \mathrm{~K}$ nominal) flames at a height of $25 \mathrm{~mm}$ above the fuel jet exit.

FIGURE 3.13. Radial temperature profiles for undiluted, fuel-diluted $(Z=0.15)$, and air-diluted $(Z=0.15)$ preheated $(400 \mathrm{~K}$ nominal) flames at a height of $50 \mathrm{~mm}$ above the fuel jet exit.

FIGURE 3.14. Radial temperature profiles at the visible flame tips for undiluted, fuel-diluted $(Z=0.15)$, and air-diluted $(Z=0.15)$ preheated (400 $K$ nominal) flames. The axial positions are 50,55 , and $60 \mathrm{~mm}$ for the undiluted, fuel-diluted, and air-diluted flames, respectively.....

FIGURE 3.15. $\mathrm{NO}_{2}$-to $\mathrm{NO}_{\mathrm{x}}$ molar ratios for laminar jet flames with various levels of $\mathrm{N}_{2}$ dilution in either the fuel or air stream.

FIGURE 3.16. Carbon monoxide emission indices for laminar jet flames with various levels of $\mathrm{N}_{2}$ dilution in either the fuel or air stream. 
FIGURE 3.17. $\mathrm{NO}_{\mathrm{x}}$ emission indices for laminar non-sooting $\mathrm{CH}_{4}\left(\mathrm{~N}_{2}\right)$ jet flames with various levels of dilution in either the fuel or air stream starting from the nominally fuel-diluted, $Z=0.2$, baseline condition. The $\mathrm{CH}_{4}\left(\mathrm{~N}_{2}\right)$ fuel flowrate is held constant as the diluent is added. 


\section{LIST OF TABLES}

TABLE 2.1. $\quad \mathrm{N}_{2}$ Mass Fraction, Mixture Density, Mixture Mass Flux, and Mixture Momentum Flux for Pure and $N_{2}$-Diluted $(Z=0.15)$ Fuel and Air Streams $(T=300 \mathrm{~K})$

TABLE 2.2. Test Conditions for Selected Numerical Simulations of $\mathbf{C H}_{4}$-Air Counterflow Diffusion Flames with Reactants at $300 \mathrm{~K}$

TABLE 2.3. Rate of Fuel Supplied From Nozzle, Residence Time, Fuel Consumption Rate, and Fraction of Fuel Burned $\left(\mathrm{CH}_{4}-\mathrm{Air}, \mathrm{T}=\right.$ $300 \mathrm{~K})$

TABLE 2.4. Location of Stagnation Plane and Flame, Peak Flame Temperature, and Velocity and $\mathrm{N}_{2}$ Mole Fraction at Peak Flame Temperature $\left(\mathrm{CH}_{4}\right.$-Air, $\left.\mathrm{T}=300 \mathrm{~K}\right)$.

TABLE 2.5. Contributions of Various Factors to NO Emission Index $\left(\mathrm{CH}_{4}\right.$ Air, $\mathbf{T}=300 \mathrm{~K}$ )

TABLE 3.1. Baseline Experimental Flame Conditions (No-Dilution).

TABLE 3.2. Baseline Non-Sooting Experimental Flame Condition, $\mathrm{CH}_{4}\left(\mathrm{~N}_{2}\right)$ Fuel 


\section{NOMENCLATURE}

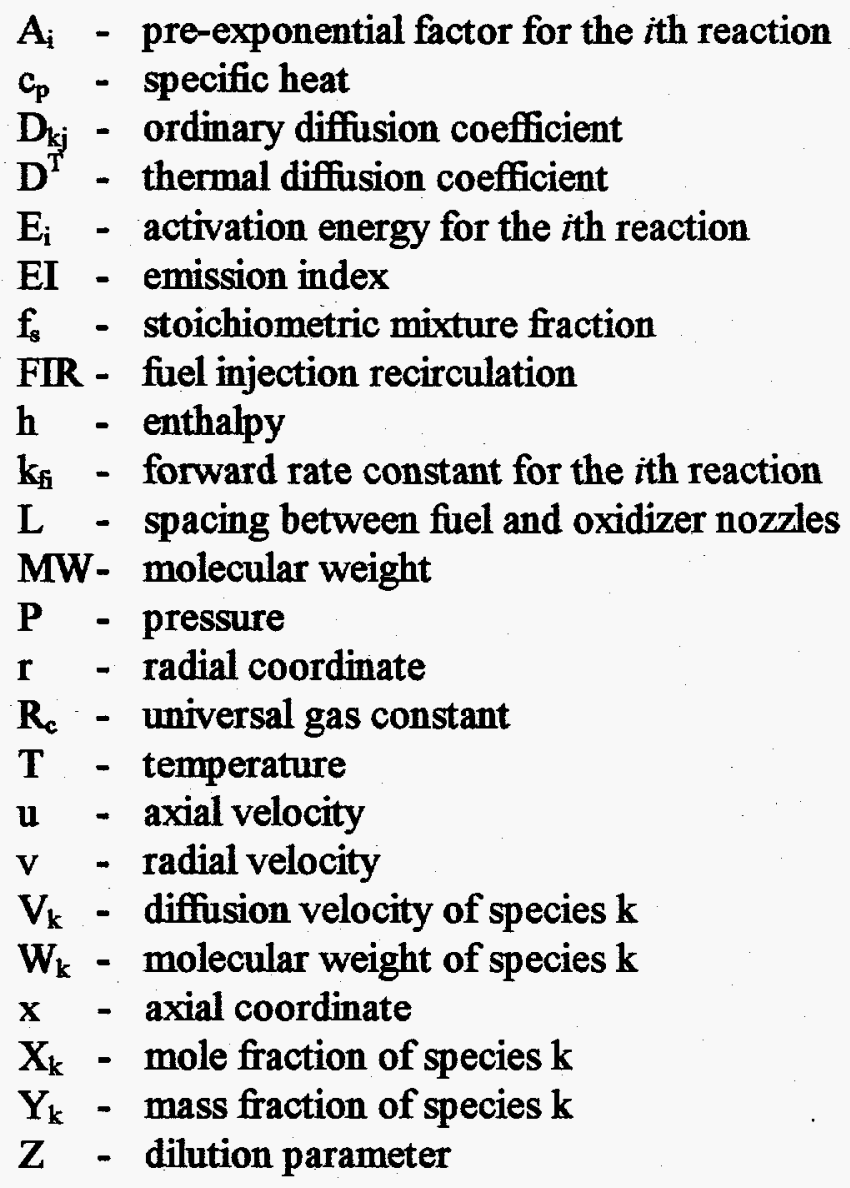

Greek Symbols

$\beta_{i}$ - temperature exponent for the $i$ th reaction

$\varepsilon \quad$ - emissivity

$\lambda$ - thermal conductivity

$\mu \quad$ - absolute viscosity

$\rho$ - density

$\sigma \quad$ - Stefan-Boltzmann constant

$\psi \quad$ - stream function

$\dot{\omega}_{\mathbf{k}}-$ molar production rate of species $\mathbf{k}$ 


\section{Subscripts}

$$
\begin{aligned}
& \mathbf{b} \text { - bead } \\
& \text { dil }- \text { diluent } \\
& \mathbf{F u} \text { - fuel } \\
& \mathbf{g} \text { - gas } \\
& \infty \text { - ambient } \\
& \mathbf{i}-\text { reaction } \\
& \mathbf{k} \mathbf{j} \text { - species } \mathbf{k} \text { or } \mathbf{j} \\
& \mathbf{o}-\text { initial } \\
& \mathbf{O x}-\text { oxidizer } \\
& \mathbf{P r}-\text { products } \\
& \text { recir- recirculated } \\
& \text { tot - total }
\end{aligned}
$$




\section{Chapter 1}

\section{INTRODUCTION}

\subsection{Motivation}

Increasingly stringent government regulations of nitrogen oxide $\left(\mathrm{NO}_{\mathrm{x}} \equiv \mathrm{NO}+\right.$ $\mathrm{NO}_{2}$ ) emissions from industrial and utility boilers are demanding a more advanced understanding of $\mathrm{NO}_{\mathrm{x}}$ formation and the rational application of this understanding to $\mathrm{NO}_{\mathrm{X}}$ control strategies. Flue gas recirculation (FGR) is a well-known technique for $\mathrm{NO}_{\mathrm{X}}$ control in industrial burner applications. In this technique, flue gases are mixed with the air supply prior to combustion. The recirculated flue gases decrease peak flame temperatures resulting in lower thermal $\mathrm{NO}_{\mathrm{X}}$ production rates. Recent small-scale boiler experiments by Hopkins et al. [1] have demonstrated that introducing the flue gas with the fuel results in a much greater reduction in $\mathrm{NO}_{\mathrm{X}}$, per unit mass of recirculated gas, than when the flue gas is mixed with the air. This relatively new $\mathrm{NO}_{\mathrm{x}}$ control technique is referred to as fuel injection recirculation (FIR). Figure 1.1 illustrates the effectiveness of FIR in comparison to FGR. Here we see that the $\mathrm{NO}_{\mathrm{X}}$ yield was decreased from $90 \mathrm{ppm}$ at the baseline operating condition to $30 \mathrm{ppm}$ with only $5 \%$ FIR, while approximately $23 \%$ conventional windbox FGR was required to achieve this same reduction.

FIR appears to be a very promising and inexpensive means of meeting government regulations of $\mathrm{NO}_{\mathrm{X}}$ emissions from industrial burners. Unfortunately, there is little physical 


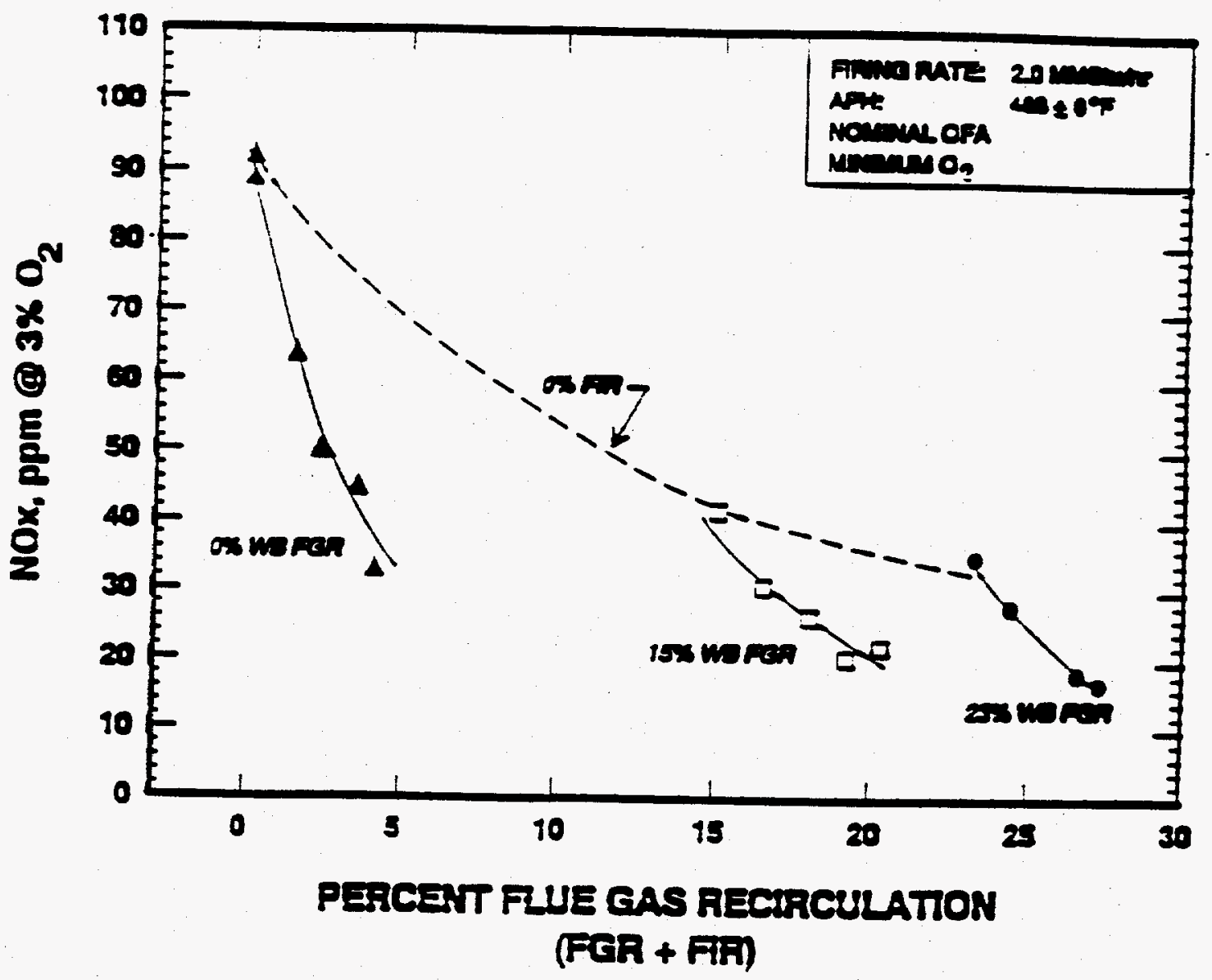

FIGURE 1.1. Effect of flue gas recirculation on $\mathrm{NO}_{x}$ emissions illustrating the greater effectiveness of introducing the flue gas with the fuel (FIR) versus mixing the flue gas with the air in the windbox (WB FGR). From reference [1]. 
understanding of why FIR is more effective than conventional FGR Hopkins et al. speculate that the production of $\mathrm{NO}_{\mathrm{x}}$ through the Fenimore mechanism may be suppressed [1]. On a simple heat-capacity basis, the reduction in flame temperature resulting from recirculated flue gas should not depend on whether the gas is mixed with the air or the fuel, but only on the quantity recirculated. In lean flames, where equivalence ratios are less than unity, a portion of conventional FGR may be wasted. This is especially true in lean nonpremixed systems where a portion of the air is not used in combustion, but may mix with the products. Since the diluent is mixed with the fuel in the FIR process, we can assume that all the diluent is effective in the combustion process. A better understanding of how FIR affects chemical kimetics and transport mechanisms as well as its influence on flame structure is needed to understand why FIR is more effective than FGR. This knowledge will aid in the optimization of FIR in a variety of industrial applications.

The majority of industrial and utility combustion systems operate as turbulent diffusion or premixed flames. Understanding the complex interaction between chemical kinetics, turbulent transport of species and energy, and flame structure in these turbulent flames is very difficult. Laminar diffusion flames provide a simple environment to study some of these complex phenomena without the added difficulty of turbulent transport processes. For example, the steady-state nature of laminar diffusion flames permits us to obtain velocity and temperature profiles throughout these flames fairly easily. Once these quantities are known, we can focus our attention on chemical kinetics. The objective of this work is to ascertain whether or not chemical and/or molecular transport effects alone, uncoupled from the turbulence problem, can explain the greater effectiveness of FIR in 
comparison to FGR. For instance, these laminar flame studies should reveal if FIR alters the chemical kinetics by suppressing the formation of $\mathrm{NO}_{\mathrm{x}}$ through the Fenimore mechanism as speculated by Hopkins et al [1].

In the present study, $\mathrm{NO}_{\mathrm{x}}$ formation is investigated in both numerical and experimental laminar diffusion flames with the overall objective of determining why FIR is more effective than conventional FGR. The numerical model consists of a counterflow flame geometry and utilizes the well-known Miller-Bowman [2] chemical kinetics for the C-O-H-N system. The experimental set-up consists of a coannular laminar diffusion flame burner. Both of these flames provide stable environments in which the factors affecting $\mathrm{NO}_{\mathrm{X}}$ formation can be controlled and measured in a relatively straightforward manner while still maintaining some connections with industrial combustion systems. For example, the opposed flow laminar diffusion flame model can be used as a prototype model for laminar flamelets in turbulent diffusion flames [3].

\subsection{Fundamentals of NO Formation}

Although they constitute only trace products of the combustion process, nitrogen oxides are highly toxic pollutants that contribute to photochemical smog, particulate $\mathrm{NH}_{3} \mathrm{NO}_{3}$ formation, acid rain, depletion of the ozone layer, and sickness in humans. In fuels not containing nitrogen, the formation of $\mathrm{NO}_{\mathrm{x}}$ can be classified according to three primary mechanisms involving nitrogen from the air: (1) the thermal or Zeldovich 
mechanism, (2) the Fenimore or prompt mechanism, and (3) the $\mathrm{N}_{2} \mathrm{O}$-intermediate mechanism [4].

Nitrogen oxides are normally present in the atmosphere in low concentrations. Natural sources of NO, such as lightning and forest fires, account for approximately $30 \%$ of the total global sources of $\mathrm{NO}_{\mathrm{x}}$, while the other $70 \%$ are produced from human sources. Fossil fueled combustion, including mobile and stationary sources, contributes almost $40 \%$ of the total $\mathrm{NO}_{\mathrm{x}}$ produced [5]. Since 1900 , global $\mathrm{NO}_{\mathrm{x}}$ emissions from combustion sources have increased by a factor of ten, with emissions increasing by more than a factor of three since 1950 . The oxides of nitrogen have proved to be the most intractable of gaseous pollutants from combustion of fuels containing little or no sulfur. This is partly explained by the fact that they were the last to be recognized as a nuisance, and the obvious steps customarily taken to reduce emissions of carbon monoxide (CO), unburnt hydrocarbons $(\mathrm{HC})$, and soot tended to maximize $\mathrm{NO}_{\mathrm{x}}[6]$.

Regulation of $\mathrm{NO}_{\mathrm{x}}$ emissions is controlled by government legislation imposed by the National Ambient Air Quality Standards, New Source Performance Standards (NSPS), and the Clean Air Act. The 1982 Air Quality Standards set the maximum annual average $\mathrm{NO}_{2}$ levels for an area to $100 \mu \mathrm{g} / \mathrm{m}^{3}$ [7]. The variability of $\mathrm{NO}_{\mathrm{x}}$ sources impacts the nature of the $\mathrm{NO}_{\mathrm{x}}$ emissions regulations needed in specific geographical areas to meet ambient air quality standards [5]. In general, California emission standards are among the most strict in the nation, and California frequently leads the nation in subjecting new and existing sources to control [4]. 


\subsubsection{NOx Formation Mechanisms}

The first mechanism for NO formation was proposed by Zeldovich in 1947 and is commonly referred to as the thermal mechanism. The following three reactions comprise the thermal mechanism:

$$
\begin{aligned}
& \mathrm{O}+\mathrm{N}_{2} \rightarrow \mathrm{NO}+\mathrm{N} \\
& \mathrm{N}+\mathrm{O}_{2} \rightarrow \mathrm{NO}+\mathrm{O} \\
& \mathrm{N}+\mathrm{OH} \rightarrow \mathrm{NO}+\mathrm{H}
\end{aligned}
$$

Equation 1.1 is the rate-limiting step in the NO formation process. Fixation of nitrogen requires breaking the unusually strong bond of the $\mathbf{N}_{2}$ molecule. The dissociation energy of $\mathrm{N}_{2}$ is rather large $(941 \mathrm{KJ} / \mathrm{mol})$ [6]; thus, Eqn. 1.1 has a very strong temperature dependence. In fact, the thermal mechanism is frequently considered unimportant at temperatures below $1800 \mathrm{~K}$. Compared to the time scales of fuel oxidation processes in premixed flames, the formation of NO through the thermal mechanism is quite slow; therefore, thermal NO is generally considered to be formed in the post-flame gases [4]. The importance of residence time should be emphasized: the longer the NO producing species remain at high temperatures, the greater the thermal NO production rate, provided NO concentrations are well below equilibrium values.

The rapid formation of NO in the reaction zone of laminar premixed flames was discovered by Fenimore, which he termed "prompt" NO [8]. The prompt mechanism is 
intimately linked to the combustion chemistry of hydrocarbons and accounts for rapid NO formation which cannot be explained by the thermal mechanism. The reactions and species involved in the Fenimore mechanism can be quite complex; therefore, the detailed chemical pathways, which vary according to stoichiometry, flame type, etc., will not be given. Generally, the process involves the attack by a hydrocarbon fragment on molecular nitrogen:

$$
\mathrm{CH}+\mathrm{N}_{2} \rightarrow \mathrm{HCN}+\mathrm{N}
$$

resulting in amino and cyano compounds. The amino and cyano compounds are then converted to intermediate compounds that ultimately form NO [4].

Figure 1.2 illustrates a reaction path diagram for the formation of NO via the prompt and thermal mechanisms in an opposed flow laminar diffusion flame burning methane [9]. Here we see the complex relationship between the various NO formation pathways. Miller and Bowman [2] point out the large recycling of $\mathrm{NO}$ to form $\mathrm{HCN}$ via $\mathrm{HCNO}$ and $\mathrm{CH}_{\mathrm{i}}$, which inhibits NO production.

Finally, the $\mathrm{N}_{2} \mathrm{O}$-intermediate mechanism for NO production is important in fuellean, low-temperature combustion. The steps involved are as follows:

$$
\begin{aligned}
& \mathrm{O}+\mathrm{N}_{2}+\mathrm{M} \rightarrow \mathrm{N}_{2} \mathrm{O}+\mathrm{M} \\
& \mathrm{H}+\mathrm{N}_{2} \mathrm{O} \rightarrow \mathrm{NO}+\mathrm{NH} \\
& \mathrm{O}+\mathrm{N}_{2} \mathrm{O} \rightarrow \mathrm{NO}+\mathrm{NO}
\end{aligned}
$$




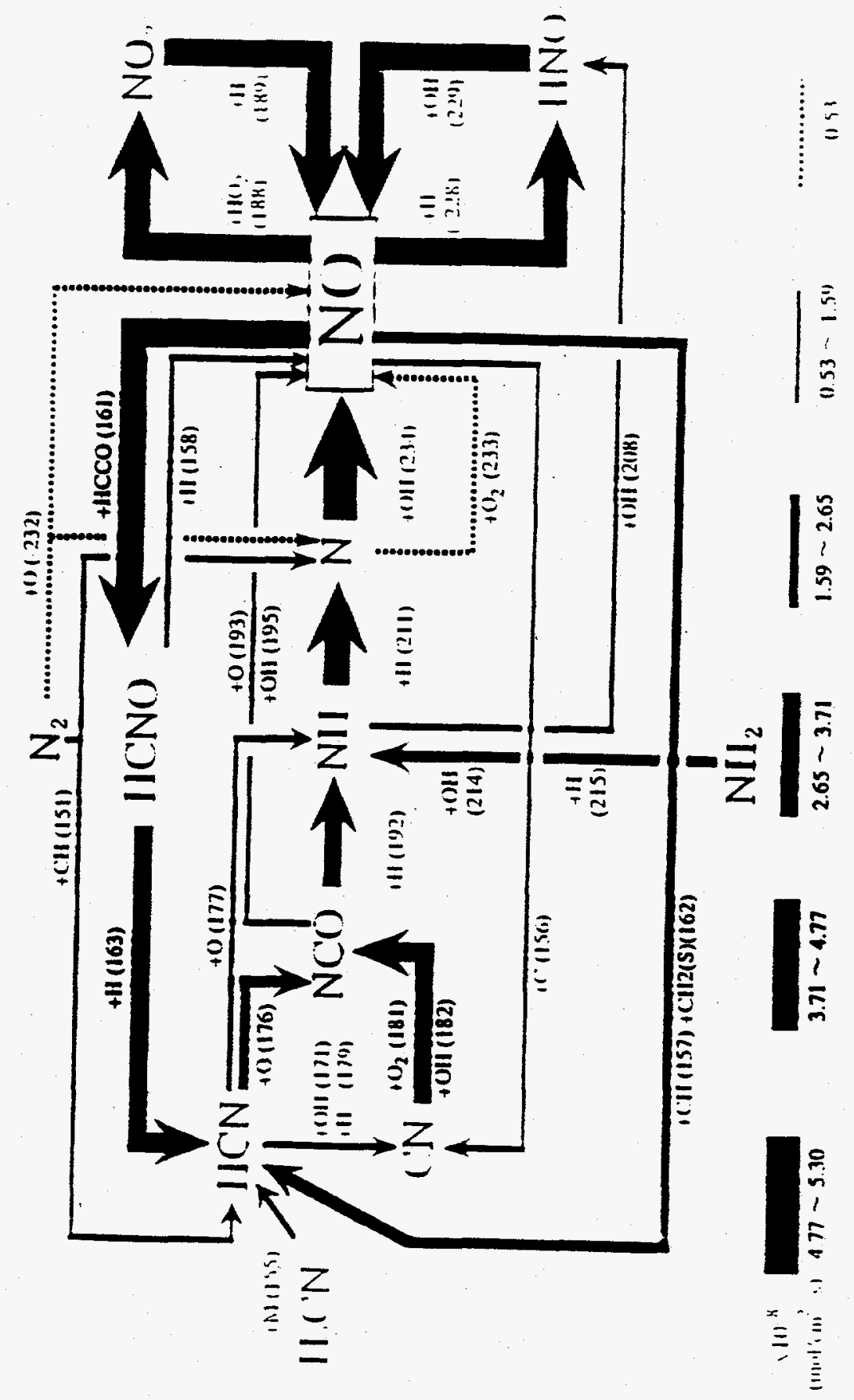

$=$

豙

.

三

三

ฏ

竞

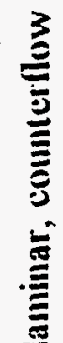

E

$\equiv$

$\equiv$

三

五

蜍

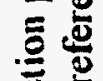

昰

ว

를

咅亥

छ

$\underset{\Xi}{\underline{\Xi}}$ 
The $\mathrm{N}_{2} \mathrm{O}$-intermediate mechanism is important in applications using lean premixed combustion which is of current interest to gas-turbine manufacturers [4].

\subsubsection{Laminar Diffusion Flames}

As previously mentioned, this work utilizes both numerical modeling and experimental efforts to clarify how FIR affects chemical kinetics and molecular transport processes in comparison to FGR. The numerical model consists of a counterflow diffusion flame geometry. Fuel issues from a circular nozzle horizontally opposed to a similar nozzle from which the oxidizer issues. A flat one-dimensional flame is established between the two nozzles. Detailed chemical kinetics are employed for $\mathrm{H}_{2}$-air and $\mathrm{CH}_{4}$-air combustion. The experimental work utilizes a coannular diffusion flame bumer and involves $\mathrm{CH}_{4}$-air flames only.

The counterflow geometry is frequently used in numerical analysis due to its relative simplicity. The flat opposed-flow flame is one-dimensional in temperature, concentration, and axial velocity profiles, provided the correct boundary conditions are employed. As a result of this simplification to one-dimensionality, extensive chemical kinetic mechanisms can be incorporated into numerical flame models, which require only relatively modest run times. Numerical $\mathbf{C H}_{4}$-air flame studies conducted by Hahn and Wendt [10] further verified the validity of the opposed-flow diffusion flame model. Their work employed the use of a kinetic mechanism for methane oxidation, including NO formation and destruction, based on evaluations by Levy et al. [11]. The numerical 
predictions for the structure of the reaction zone as well as the resultant trace species for $\mathrm{NO}_{\mathrm{x}}$ chemistry agreed well with experiment. Similar agreement between numerical predictions and experiments were obtained by Smooke et al. in 1986 [12], further verifying the usefulness of the counterflow flame model.

A most insightful study of counterflow diffusion flames is that of Nishioka et al. in 1994 [13]. Their numerical model utilized the detailed chemical kinetic scheme for methane combustion, including $\mathrm{NO}_{\mathrm{x}}$ chemistry, derived by Miller and Bowman [2]. The results of Nishioka et al. clarify the relative contribution of the various chemical pathways to the formation of $\mathrm{NO}_{\mathrm{X}}$ (Fig. 1.3). These results show that increasing flame strain decreases thermal NO very rapidly, while for prompt NO, increasing strain first increases and then gradually decreases the prompt NO yield [13]. In Fig. 1.3, we see the importance of both thermal and prompt NO in these counterflow diffusion flames. In general, the prompt mechanism makes the largest contribution to the NO emission index, followed by the thermal mechanism.

Smyth [14] quantified the relative importance of prompt and thermal NO formation routes in experimental $\mathrm{CH}_{4}$-air diffusion flames burning on a Wolfhard-Parker slot burner. Both the overall NO production/destruction rates and the contributions from the prompt and thermal routes were derived from detailed measurements of radical profiles. Smyth concluded that at early times the instantaneous rate of prompt production is larger than the thermal mechanism route. However, overall NO production via the prompt mechanism was believed to be largely offset by fast $\mathrm{NO}+\mathrm{CH}_{\mathrm{i}}$ consumption reactions. NO concentration profile measurements exhibited peak values at the local 


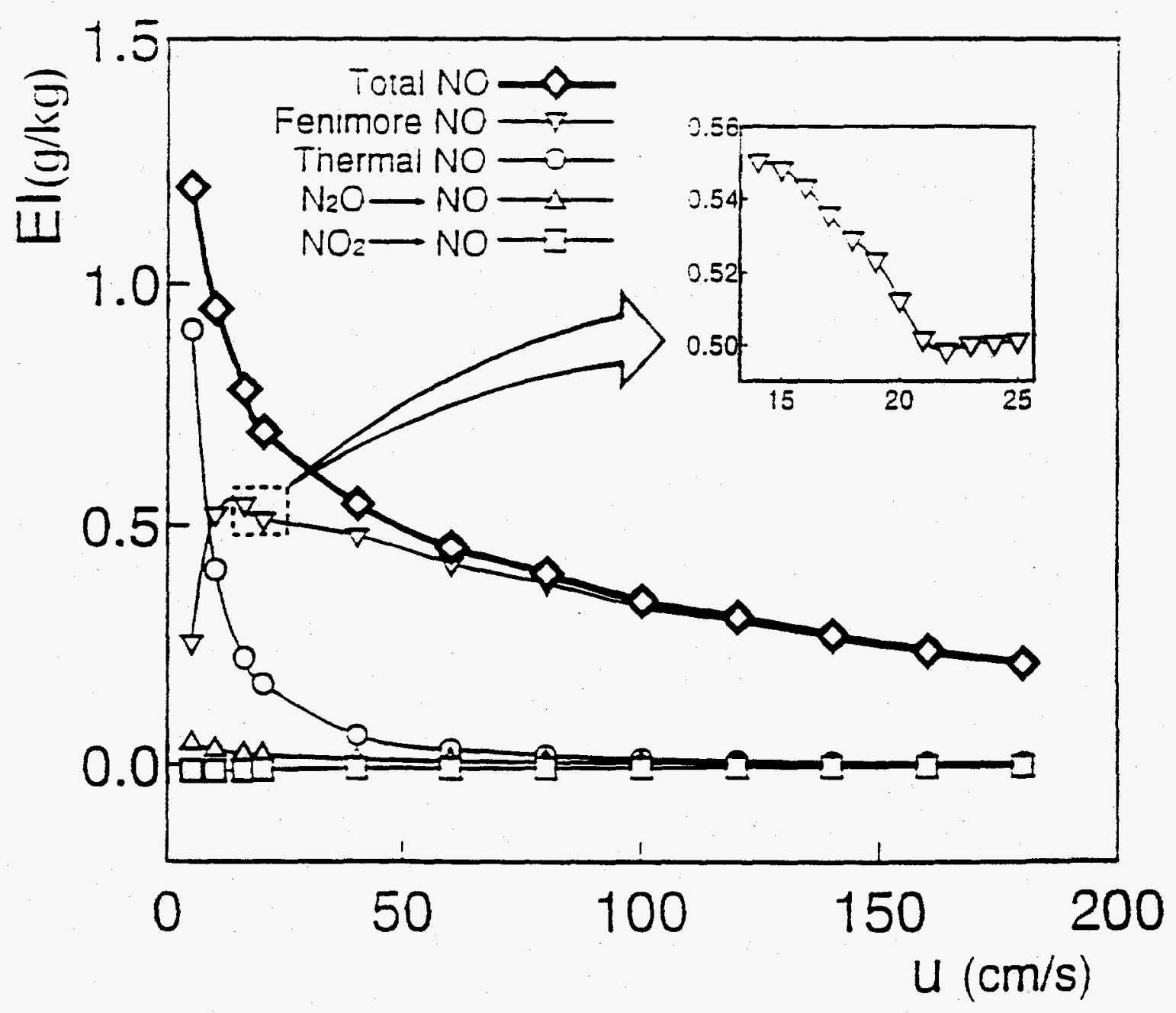

FIGURE 1.3. Calculated NO emission indices for $\mathrm{CH}_{4}$-air, laminar, counterflow diffusion flames showing contributions by various chemical routes. From reference [13]. 
temperature maxima in the flame, coincident with the predicted peak production rate of NO for the thermal pathway [14]. In conclusion, both the prompt and thermal pathways were identified as significant contributors to the NO emission, which is consistent with the work of Nishioka et al. [13].

The earliest work involving the theoretical description of diffusion flames was that of Burke and Schumann [15]. Their theory predicted flame geometry fairly well in both under-ventilated and over-ventilated diffusion flames using a number of simplifying assumptions. For an over-ventilated diffusion flame, which is used in the present study, surplus oxidant is available for complete combustion of the fuel. Under the assumptions that (1) the velocity field was everywhere constant and parallel to the flame axis, (2) the coefficient of molecular diffusion between the two gas streams was constant, (3) axial diffusion could be ignored, and (4) all mixing was entirely a result of diffusion, Burke and Schumann's theory predicted flame lengths reasonably well for axisymmetric (circularport) flames [15].

Based on the success of Burke and Schumann, Roper [16], in 1977, published a new theory to predict flame height. This theory retained the simplicity of the Burke and Schumann analysis but relaxed the constraint of constant velocity. The flame height, $\mathbf{L}_{\mathrm{f}}$, was found to be related to the volumetric flow, $\mathrm{Q}_{\mathrm{F}}$, through a circular tube by:

$$
L_{f}=\frac{Q_{F}\left(T_{\infty} / T_{F}\right)}{4 \pi D_{\infty} \ln (1+1 / S)}\left(\frac{T_{\infty}}{T_{f}}\right)^{0.67}
$$

where $S$ is the molar stoichiometric oxidizer-fuel ratio, $D_{\infty}$ is the mean diffusion coefficient at the oxidizer stream temperature, and $T_{\infty}, T_{F}$, and $T_{f}$ are the oxidizer stream, fuel stream, 
and mean flame temperatures, respectively. The effect on flame length of adding an inert species, such as flue gas, can be accounted for in Eqn. 1.8 by adjusting the molar stoichiometric ratio, $\mathbf{S}$.

\subsection{Objectives and Outline}

The objective of the present work is to develop an understanding of how the detailed chemical environment and NO formation is affected by the location of added diluent, i.e., fuel stream (FIR) or air stream (FGR) in laminar diffusion flames. This knowledge will aid in the rational application and optimization of FIR in a variety of industrial applications. Also, this understanding will aid future studies of turbulent flames which involve the additional complexity of turbulent transport of species and energy.

Both the numerical and experimental studies investigate the role of chemical and molecular transport effects on $\mathrm{NO}_{\mathrm{x}}$ formation in fuel-diluted and air-diluted flames. Throughout this work, $\mathbf{N}_{2}$ is used as the diluent to simulate flue gases. Since $\mathbf{N}_{2}$ is the major constituent of flue gases, this is a reasonable simulation. Other important parameters to be studied are the quantity of diluent, initial reactant temperatures, and reactant flow rates or strain rates.

Chapter 2 provides a detailed description of the numerical model employed for both hydrogen and methane combustion including governing equations, chemical kinetic models, and important parameters used in the simulations. Hydrogen flames were included in the study because only the thermal NO mechanism is active; thus, they avoid 
the complications of prompt NO formation routes. Following the numerical model description, both the hydrogen-air and methane-air flame results are presented and discussed in detail.

Chapter 3 includes a description of the experimental set-up and the measurement techniques used to obtain detailed information on temperatures and species in the air- and fuel-diluted flames. This information is followed by experimental test conditions. The $\mathrm{CH}_{4}$-air experimental flame results are then presented and discussed in detail. Finally, Chapter 4 provides conclusions based on the numerical and experimental flame results and recommendations for future work. 


\section{Chapter 2}

\section{NUMERICAL METHOD}

\subsection{Model Description}

The counterflow diffusion flame model used in this study is that developed by Kee et al. [17] and extended by Lutz [18]. A counterflow diffusion flame, shown in Fig. 2.1, is established between two concentric, circular nozzles directed towards each other.

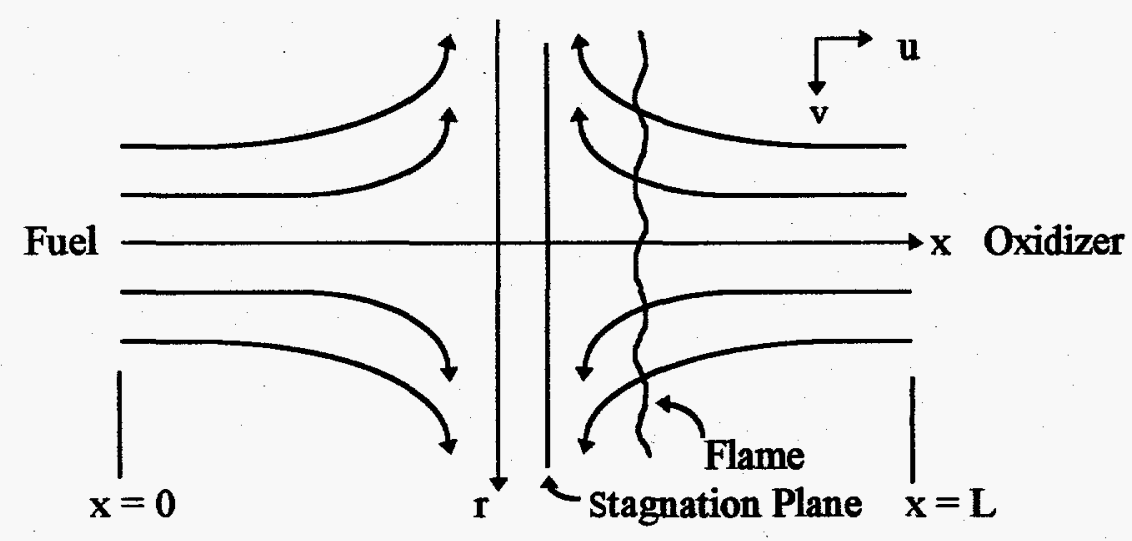

FIGURE 2.1. Counterflow diffusion flame geometry showing location of flame and stagnation plane.

The location of the stagnation plane depends on the momentum balance of the opposing streams. Since most fuels require more air than fuel by mass, the flame is usually located on the oxidizer side of the stagnation plane. The two-dimensional flow is reduced to one dimension by assuming the species mass fractions, temperature, and velocity are 
functions only of the axial coordinate, $x$, and the radial velocity varies linearly in $r$. [17]. As a result of this simplification to one-dimensionality, very extensive chemical kinetic mechanisms can be incorporated into numerical flame models, which require only relatively modest run times.

\subsubsection{Governing Equations and Solution}

The counterflow diffusion flame model [17] can be summarized as follows: A stream function, $\psi$, defined as

$$
\psi(\mathbf{x}, \mathbf{r})=\mathbf{r}^{2} \mathbf{F}(\mathbf{x})
$$

satisfies conservation of mass when

$$
\frac{\partial \psi}{\partial \mathbf{r}}=\mathbf{r} \rho \mathbf{u}
$$

and

$$
\frac{\partial \psi}{\partial \mathbf{x}}=-\mathbf{r} \rho \mathbf{v}
$$

where $u$ and $v$ are the axial and radial velocity components respectively. This requires that $\mathbf{F}(\mathbf{x})$ be

$$
\mathrm{F}(\mathrm{x})=\frac{\rho \mathrm{u}}{2} .
$$

Defining $G(x)$,

$$
\mathrm{G}(\mathrm{x}) \equiv \frac{\mathrm{dF}}{\mathrm{dx}}=-\frac{\rho \mathrm{v}}{\mathrm{r}},
$$


and the eigenvalue, $\mathrm{H}$, from the radial momentum equation as

$$
\mathbf{H} \equiv \frac{1}{\mathbf{r}} \frac{\partial \mathbf{P}}{\partial \mathbf{r}}=\mathrm{constant}
$$

the radial momentum equation is

$$
\frac{1}{\mathrm{r}} \frac{\partial \mathrm{P}}{\partial \mathrm{r}}+\frac{1}{\mathrm{r}} \frac{\mathrm{d}}{\mathrm{dx}}(\rho \mathrm{uv})+3 \rho\left(\frac{\mathrm{v}}{\mathrm{r}}\right)^{2}-\frac{\mathrm{d}}{\mathrm{dx}}\left[\mu \frac{\mathrm{d}}{\mathrm{dx}}\left(\frac{\mathrm{v}}{\mathrm{r}}\right)\right]=0
$$

using $F$, $G$, and $H$, Eqn. 2.7 can be written as

$$
H-2 \frac{d}{d x}\left(\frac{F G}{\rho}\right)+\frac{3 G^{2}}{\rho}+\frac{d}{d x}\left[\mu \frac{d}{d x}\left(\frac{G}{\rho}\right)\right]=0 .
$$

Energy conservation, with symbols defined in the nomenclature list, is given by

$$
2 F \frac{d T}{d x}-\frac{1}{c_{p}} \frac{d}{d x}\left(\lambda \frac{d T}{d x}\right)+\frac{\rho}{c_{p}} \sum_{k} c_{p, k} Y_{k} V_{k} \frac{d T}{d x}+\frac{1}{c_{p}} \sum_{k} h_{k} \dot{\omega}_{k}=0
$$

and species conservation by

$$
2 \mathrm{~F} \frac{\mathrm{dY}}{\mathrm{dx}}+\frac{\mathrm{d}}{\mathrm{dx}}\left(\rho \mathrm{Y}_{\mathrm{k}} \mathrm{V}_{\mathrm{k}}\right)-\dot{\omega} \mathrm{k} \mathrm{W}_{\mathrm{k}}=0 \quad \mathrm{k}=1,2, \ldots \mathrm{K} .
$$

The diffusion velocities, $V_{k}$, in the above equations are calculated using

$$
\mathrm{V}_{\mathrm{k}}=\frac{1}{\mathbf{X}_{\mathrm{k}} \overline{\mathrm{W}}} \sum_{\mathrm{j}=1}^{\mathrm{K}} \mathrm{W}_{\mathrm{j}} \mathbf{D}_{\mathrm{kj}} \frac{\partial \mathbf{X}_{\mathrm{j}}}{\partial \mathrm{x}}-\frac{\mathrm{D}_{\mathrm{k}}^{\mathrm{T}}}{\rho \mathrm{Y}_{\mathrm{k}}} \frac{1}{\mathrm{~T}} \frac{\partial \mathrm{T}}{\partial \mathrm{x}}
$$

which takes into account both ordinary molecular diffusion and thermal diffusion.

The boundary conditions at the nozzles are

$$
\begin{aligned}
& \mathrm{x}=0: \quad \mathrm{F}=\frac{\rho_{\mathrm{Fu}} \mathrm{u}_{\mathrm{Fu}}}{2} ; \mathrm{G}=0 ; \mathrm{T}=\mathrm{T}_{\mathrm{Fu}} ; \mathrm{Y}_{\mathrm{k}}=\mathrm{Y}_{\mathrm{k}, \mathrm{Fu}} \\
& \mathrm{x}=\mathrm{L}: \quad \mathrm{F}=\frac{\rho_{\mathrm{Ox}} \mathrm{u}_{\mathrm{Ox}}}{2} ; \mathrm{G}=0 ; \mathrm{T}=\mathrm{T}_{\mathrm{Ox}} ; \mathrm{Y}_{\mathrm{k}}=\mathrm{Y}_{\mathrm{k}, \mathrm{Ox}}
\end{aligned}
$$


The partial differential equations (2.4) through (2.11) and boundary conditions $(2.12 a, b)$ form a boundary value problem for the dependent variables $\left(F, G, H, T, Y_{k}\right)$. The reaction rate and thermodynamic properties are provided by the Chemkin [19] library of subroutines, while a Chemkin-based package [20] evaluates the necessary transport properties. The presence of the diluent, or recirculated gases, is taken into account by specifying the species mass fractions at either the fuel-side boundary $(x=0)$ or the oxidizer-side boundary ( $x=L)$ as given above. In the present study, pure $\mathrm{N}_{2}$ was used as the diluent.

The governing equations are discretized in space by finite differences and solved using Twopnt [21], a boundary value problem solver. The Twopnt program attempts to solve the problem using Newton's method. If convergence is not obtained using Newton's method, the program resorts to time integration. After the time integration evolves the solution toward the steady state, the program returns to Newton's method to rapidly converge on the steady state solution. Once the solution is obtained on a coarse mesh, Twopnt refines the solution by adding more points into the regions of gradient or curvature in the solution [17]. It was found that an adequate solution could be obtained with approximately 130 mesh points.

\subsubsection{Chemical Kinetics}

In the numerical calculations, both hydrogen and methane flames were studied. The hydrogen oxidation mechanism, including thermal NO formation, is listed in Appendix 
A.1. The detailed mechanism for methane combustion and $\mathrm{NO}_{\mathrm{x}}$ chemistry is that of Miller and Bowman [2] and is listed in Appendix A.2. The complete Miller-Bowman mechanism employs 52 species and 235 elementary reactions. Also included in Appendix A are the rate coefficients used to calculate the reaction rate terms $\left(\dot{\omega}_{\mathbf{k}}\right)$ in the energy and species conservation equations above, i.e., Equations (2.9) and (2.10) respectively.

\subsubsection{Emission Indices}

In order to provide an unambiguous calculated measure of the amount of $\mathrm{NO}_{\mathrm{x}}$ produced in the counterflow diffusion flames, emission indices were calculated following the procedures of Takeno and Nishioka [22]. The emission index of $\mathrm{NO}_{\mathrm{x}}$ is defined as the mass of $\mathrm{NO}_{\mathrm{x}}$ emitted from the flame per mass of fuel burned. This definition permits correlation of the observed $\mathrm{NO}_{\mathrm{x}}$ in the counterflow flames to other flow fields. Based on the amount of fuel actually consumed in the flame (much of the fuel escapes combustion in the counterflow geometry), the NO emission index is expressed in terms of the NO mass fraction, $Y_{\text {NO }}$ as

$$
\mathbf{E I}_{\mathrm{NO}}=\frac{2 \int_{0}^{\mathrm{L}} \rho(\mathrm{v} / \mathrm{r}) \mathrm{Y}_{\mathrm{NO}} \mathrm{dx}}{\rho \mathrm{Y}_{\mathrm{Fu}}\left(\mathrm{u}+\mathrm{V}_{\mathrm{Fu}}\right)_{\mathrm{x}=0}-2 \int_{0}^{\mathrm{L}} \rho(\mathrm{v} / \mathrm{r}) \mathrm{Y}_{\mathrm{Fu}} \mathrm{dx}}
$$

Alternatively, the emission index can be expressed in terms of the NO production rate, $\dot{\omega}_{\text {No }}$, and the fuel consumption rate, $-\dot{\omega}_{\text {Fu }}$ : 


$$
\mathrm{EI}_{\mathrm{NO}}=\frac{\int_{0}^{\mathrm{L}} \mathrm{W}_{\mathrm{NO}} \dot{\omega}_{\mathrm{NO}} \mathrm{dx}}{-\int_{0}^{\mathrm{L}} \mathbf{W}_{\mathrm{Fu}} \dot{\omega}_{\mathrm{Fu}} \mathrm{dx}}
$$

Equation (2.13) was used to calculate the NO emission indices presented in this work.

\subsubsection{Dilution Parameter, $Z$}

In most industrial burners, the overall stoichiometry is slightly lean, with a typical $\mathrm{O}_{2}$ content of less than $1 \%$ to $3 \%$ in the product stream. The percent of flue gases recirculated, \%FGR, is typically defined as

$$
\% \mathrm{FGR}=\frac{\dot{\mathrm{m}}_{\mathrm{Pr}, \mathrm{recir}}}{\dot{\mathrm{m}}_{\mathrm{Pr}, \mathrm{tot}}} \bullet 100 \%=\frac{\dot{\mathrm{m}}_{\mathrm{Pr}, \mathrm{recoir}}}{\dot{\mathrm{m}}_{\mathrm{air}}+\dot{\mathrm{m}}_{\mathrm{Fu}}} \bullet 100 \%
$$

where $\dot{\mathrm{m}}_{\mathrm{Pr} \text {, reir }}$ is the mass flowrate of the product gases recirculated. This is an adequate definition in industrial burners in which all of the fuel is consumed; however, the counterflow flame permits much of the fuel and oxidizer to escape the flame region unused (cf. Fig. 2.1). Therefore, the overall stoichiometry associated with the flowrates of the fuel and oxidizer streams is not meaningful in the counterflow geometry. In a pure diffusion flame, it is reasonable to assume that the fuel and oxidizer react in stoichiometric $(\Phi=1)$ proportions in the flame zone $[4,23]$. This assumption provides a meaningful measure of stoichiometry on which to base the dilution parameter, $Z$. With this in mind, a dilution parameter, nominally equivalent to the FGR fraction, can be defined as 


$$
Z \equiv \frac{\text { mass of diluent }}{\text { mass of stoichiometric mixture }}
$$

This parameter can be expressed in terms of the mass fractions of diluent in the fuel and air streams, $\mathbf{Y}_{\text {dil,Fu }}$ and $\mathbf{Y}_{\text {dil,A, }}$, respectively, as

$$
Z=f_{s} \frac{Y_{d i l, F u}}{1-Y_{\text {dil Fu }}}+\left(1-f_{s}\right) \frac{Y_{d i l, A}}{1-Y_{\text {dil } A}}
$$

where $f_{s}$ is the stoichiometric mixture fraction (mass of fuel per mass of stoichiometric mixture).

To simulate conventional (windbox) FGR, $Y_{\text {dil,Fu }}$ is set to zero, and $Y_{\text {dil }, \mathrm{A}}$ is varied to produce a range of values typical to FGR. To simulate FIR, $Y_{\text {dil,A }}$ is set to zero, and $Y_{\mathrm{dil}, \mathrm{Fu}}$ is varied to produce the desired range of $\mathrm{Z}$ values. In both the numerical and experimental studies, $\mathbf{N}_{2}$ was used as the diluent for simplicity. $\mathbf{N}_{2}$ is a reasonable simulant for flue gases since $\mathrm{N}_{2}$ is the primary constituent of the flue gases.

\section{$\underline{2.2} \mathrm{H}_{2}$-Air Flame Simulation Results}

This section presents the numerical counterflow diffusion flame results for the $\mathrm{H}_{2}$ air flames studied. The boundary conditions used for the hydrogen flames specify fixed inlet velocities for both the fuel and air streams to investigate the influence of flame strain. The diluent is either added to the air stream, simulating conventional FGR, or to the fuel stream, simulating FIR. Note the addition of diluent to either the air or fuel stream did not change the fixed inlet velocity boundary conditions. Calculations were performed with initial velocities of either 10 or $100 \mathrm{~cm} / \mathrm{s}$ and fixed inlet temperatures of $300 \mathrm{~K}$ over a wide 
range of the dilution parameter, $\mathrm{Z}$. The chemical kinetics for $\mathrm{NO}_{\mathrm{x}}$ formation in the hydrogen flames is straightforward since only the thermal mechanism is active (cf. Appendix A.1). However, a more complicated molecular transport situation exists than with hydrocarbon flames, due to the importance of both differential diffusion and thermal diffusion of the light $\mathrm{H}$ and $\mathrm{H}_{2}$ species.

Figures 2.2 and 2.3 show the NO emission index versus diluent fraction, $Z$, for the $10 \mathrm{~cm} / \mathrm{s}$ and $100 \mathrm{~cm} / \mathrm{s}$ inlet velocity flames, respectively. As expected, the higher inlet velocity flames have a much lower NO emission index than the lower inlet velocity flames due to decreased residence times. As both figures indicate, for equivalent diluent fraction, $Z$, air stream dilution is substantially more effective than fuel stream dilution in lowering the NO emission index. This result is contrary to the turbulent flame results obtained by Hopkins [1] and Reese [24]. However, these contrary results are a consequence of the fixed inlet velocity boundary conditions, as is shown below.

Figures 2.4 through 2.8 help clarify the important physical processes contibuting to the differences in NO emission indices observed. The figures show temperature, species, and NO and fuel production profiles for the $10 \mathrm{~cm} / \mathrm{s}$ flames at a midrange diluent fraction, $Z=0.4$, of those explored. In Fig. 2.4, we see the maximum flame temperature with fueldilution is over $100 \mathrm{~K}$ hotter than the corresponding air dilution case. These temperature differences are a result of differences in the $\mathrm{N}_{2}$ mole fraction at the peak temperature location. The increased flame temperatures associated with fuel dilution accelerate the formation of NO through the highly temperature dependent Zeldovich mechanism, the only NO formation route active in the $\mathrm{H}_{2}$-air flames. Figure 2.5 shows the major species 


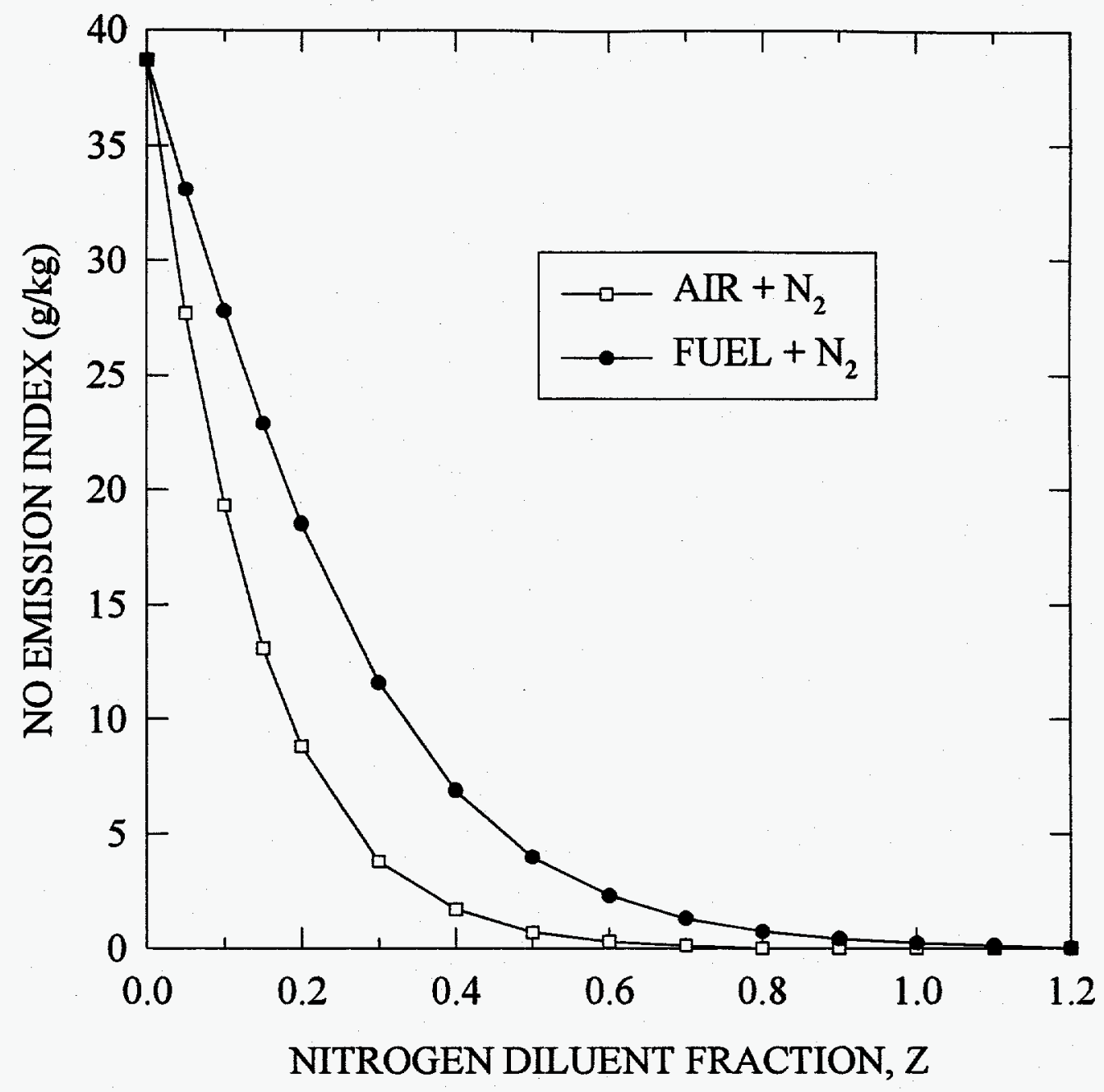

FIGURE 2.2. Calculated effect of $\mathrm{N}_{2}$ dilution on $\mathrm{NO}$ emission indices of $\mathrm{H}_{2}$-air counterflow flames in which the $\mathrm{N}_{2}$ has been added to either the air or fuel streams $\left(u_{o}=u_{F, o}=u_{O x, 0}=10 \mathrm{~cm} / \mathrm{s}\right)$. 


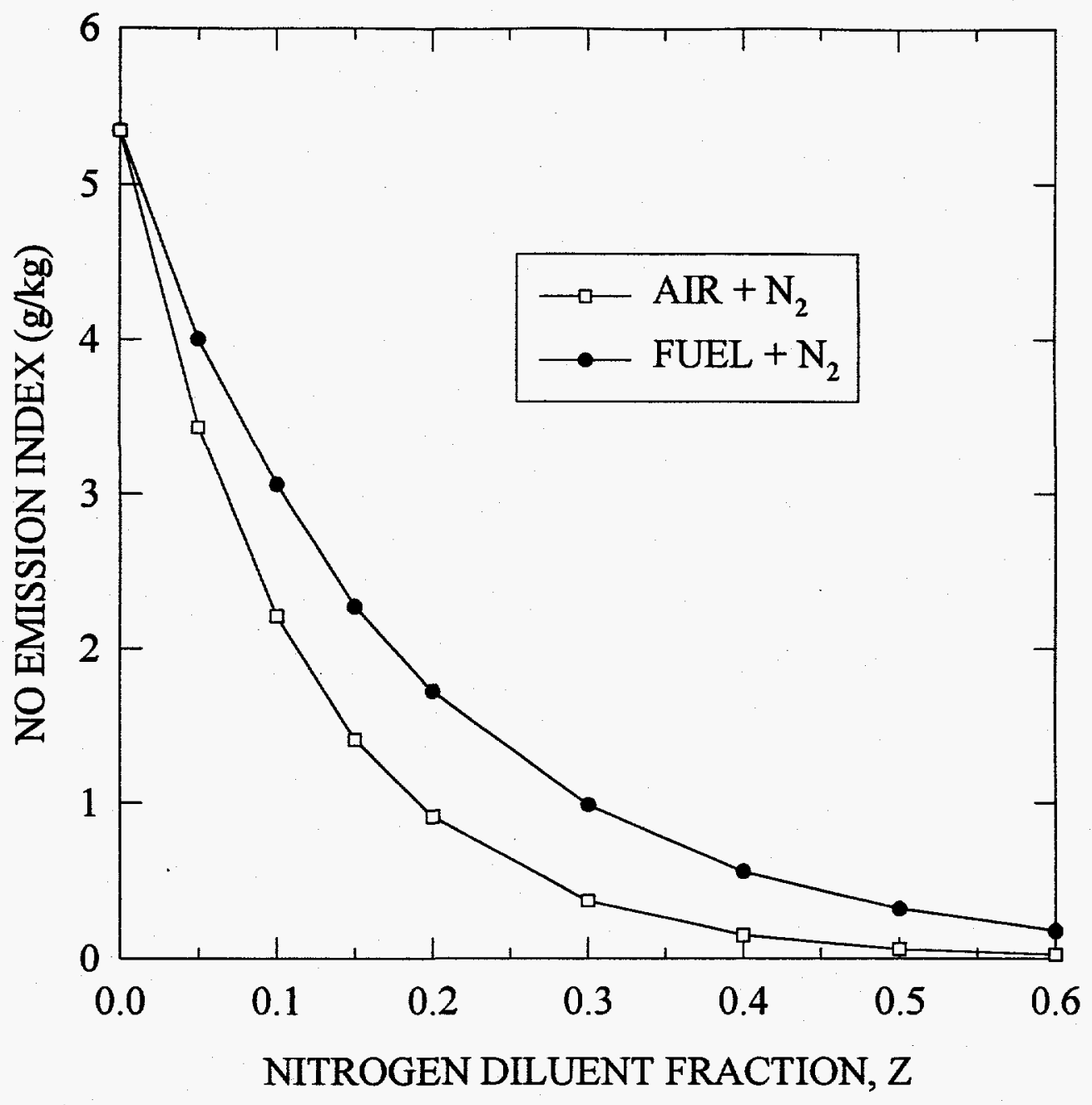

FIGURE 2.3. Calculated effect of $\mathrm{N}_{2}$ dilution on NO emission indices of $\mathrm{H}_{2}$-air counterflow flames in which the $\mathrm{N}_{2}$ has been added to either the air or fuel streams $\left(u_{0}=u_{F, 0}=u_{O x, o}=100 \mathrm{~cm} / \mathrm{s}\right)$. 


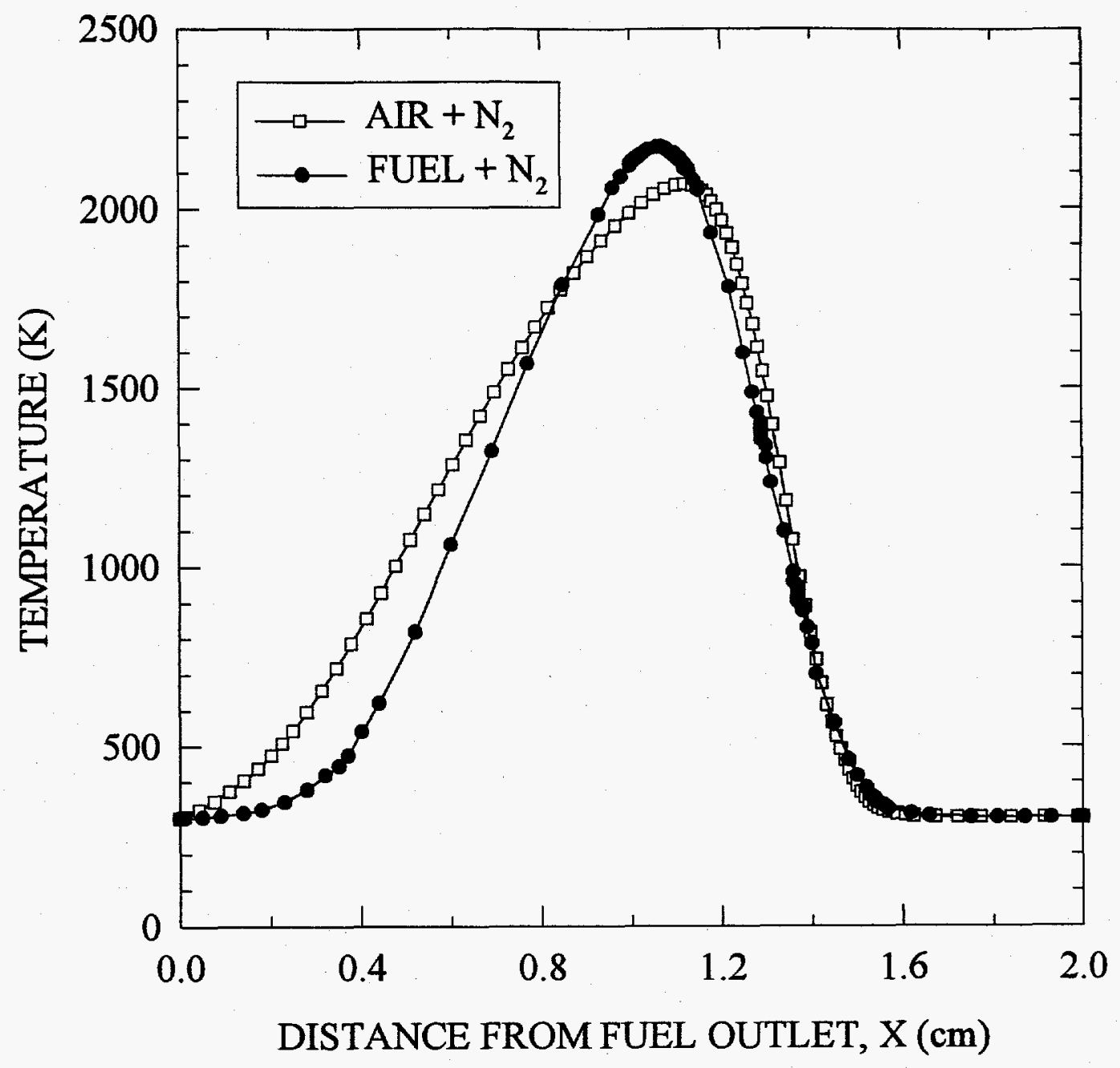

FIGURE 2.4. Calculated temperature profiles through counterflow $\mathbf{H}_{2}$-air flames for dilution of air (open symbols) or fuel (solid symbols). The diluent fraction $Z$ is $0.4\left(u_{0}=u_{F, o}=u_{O x, 0}=10 \mathrm{~cm} / \mathrm{s}\right)$. 


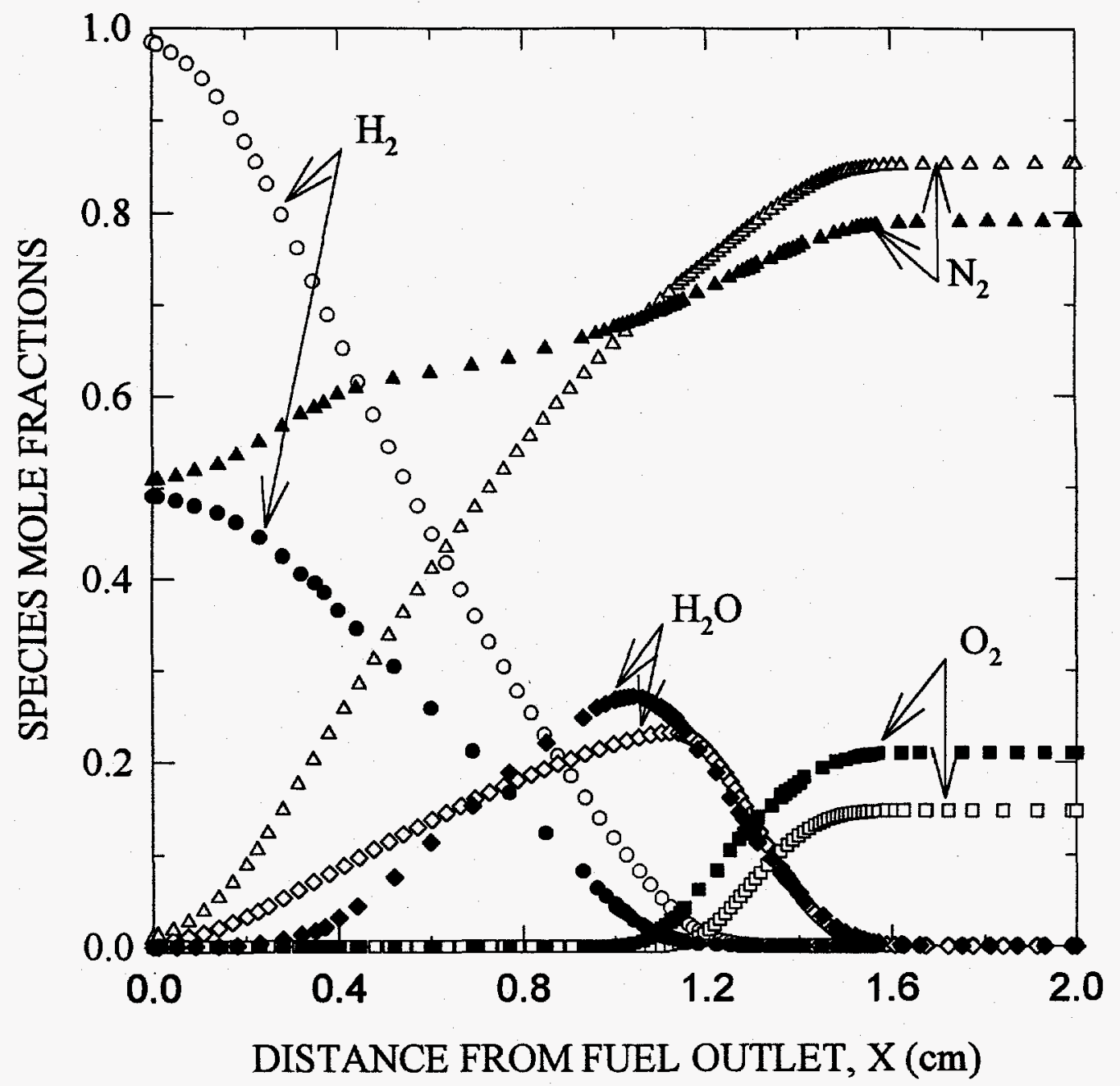

FIGURE 2.5. Calculated major species profiles through counterflow $\mathrm{H}_{2}$-air flames for $\mathrm{N}_{2}$ dilution of air (open symbols) or fuel (solid symbols). The diluent fraction $Z$ is $0.4\left(u_{0}=u_{F, 0}=u_{0,0}=10 \mathrm{~cm} / \mathrm{s}\right)$. 


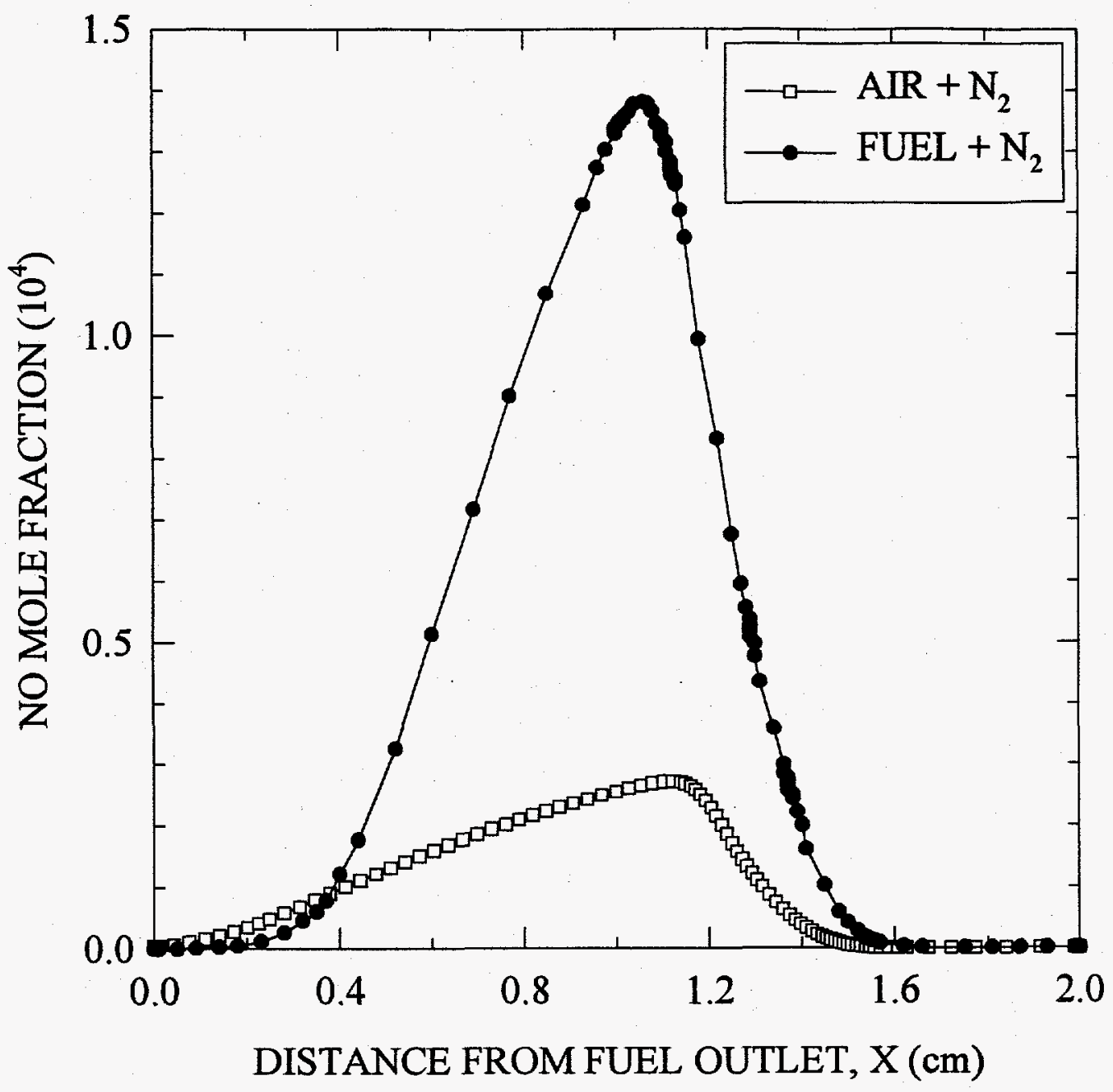

FIGURE 2.6. Calculated nitric oxide mole fraction profiles through counterflow $\mathrm{H}_{2}$-air flames for $\mathrm{N}_{2}$ dilution of air (open symbols) or fuel (solid symbols). The diluent fraction $Z$ is $0.4\left(u_{0}=u_{F, 0}=u_{O x, 0}=10 \mathrm{~cm} / \mathrm{s}\right)$. 


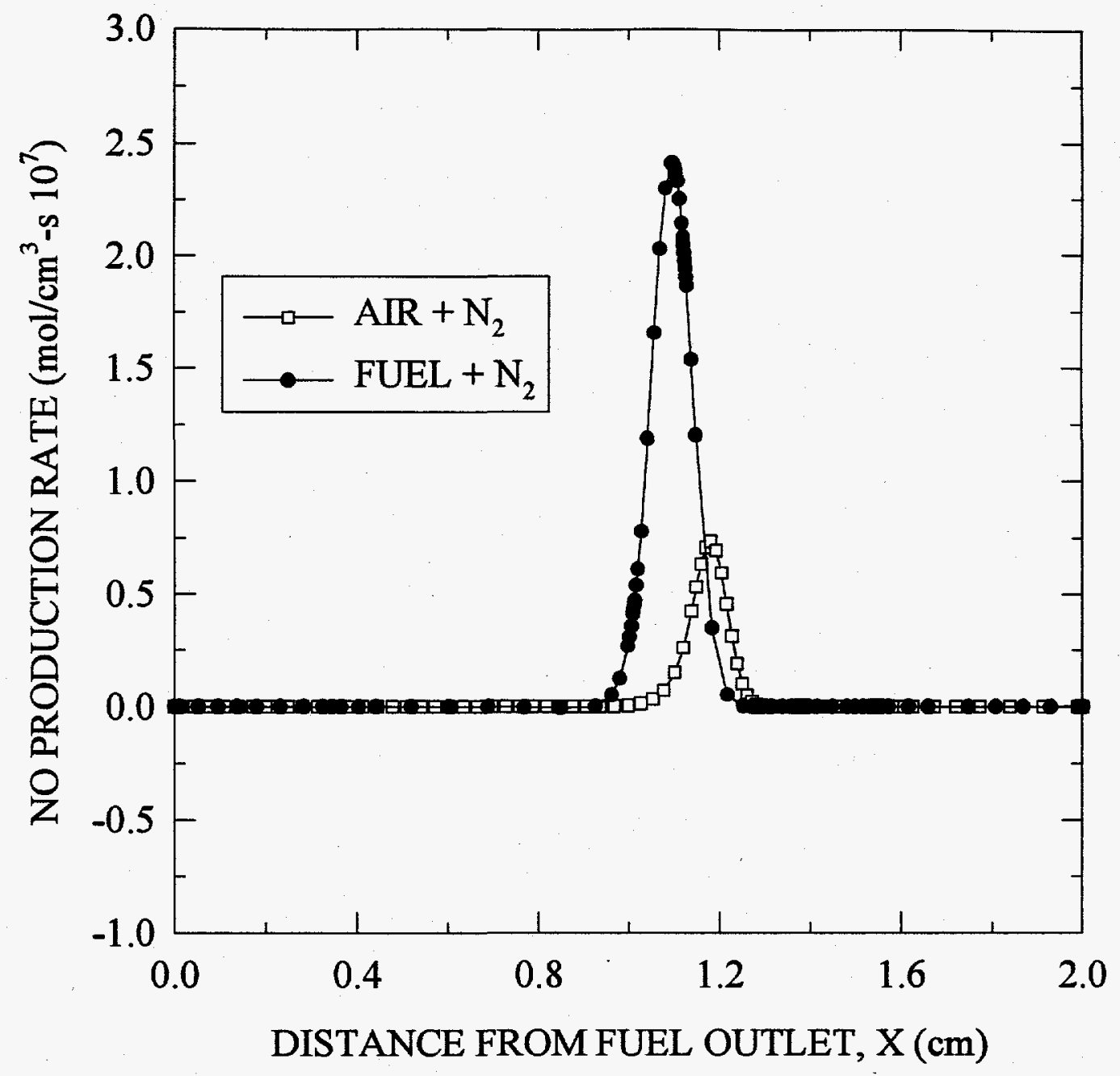

FIGURE 2.7. Calculated nitric oxide molar production rates for counterflow $\mathrm{H}_{2}$-air flames for $\mathrm{N}_{2}$ dilution of air (open symbols) or fuel (solid symbols). The diluent fraction $Z$ is $0.4\left(u_{0}=u_{F, 0}=u_{O x, 0}=10 \mathrm{~cm} / \mathrm{s}\right)$. 


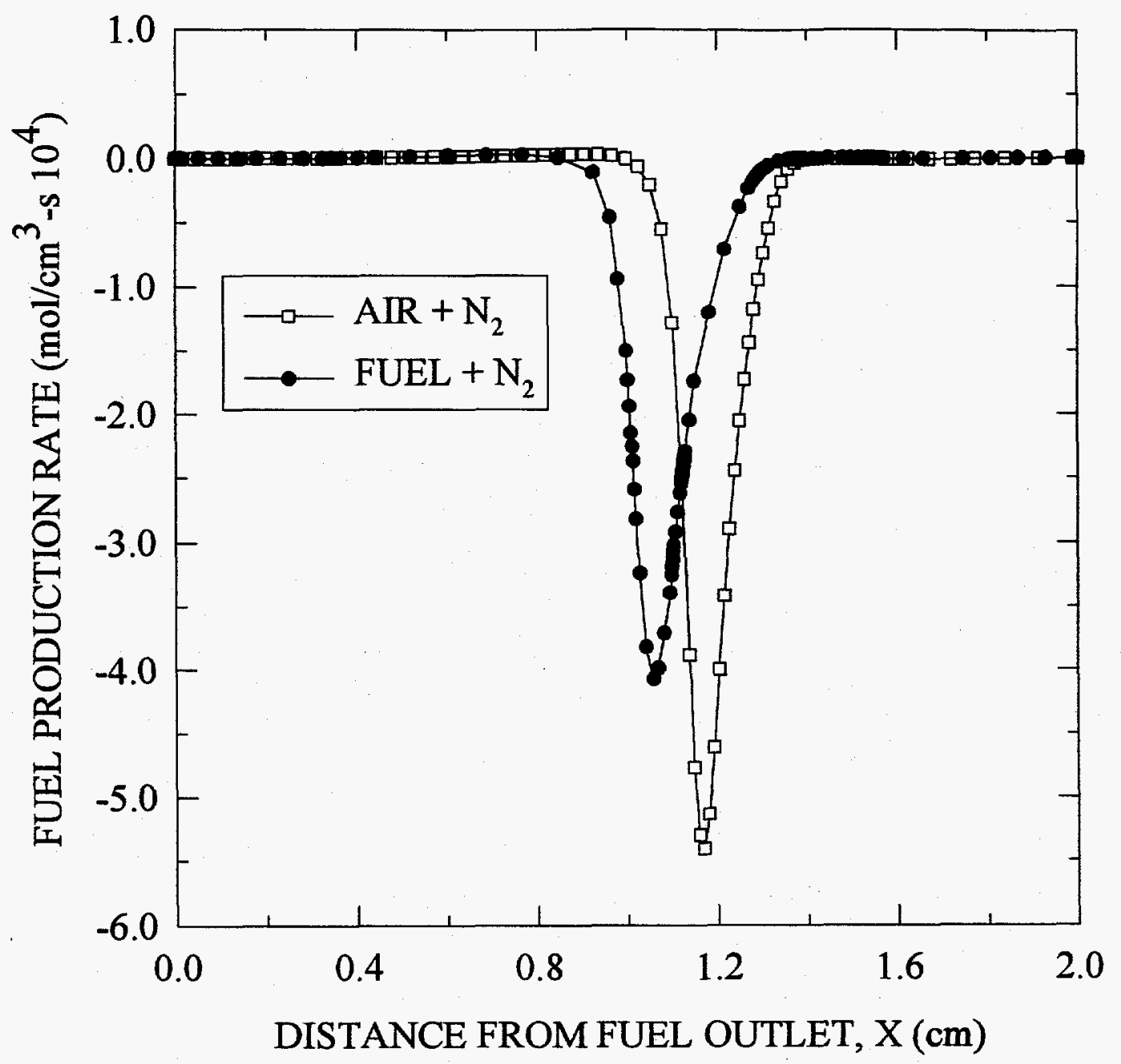

FIGURE 2.8. Calculated $\mathrm{H}_{2}$ molar production rates for counterflow $\mathrm{H}_{2}$-air flames for $\mathrm{N}_{2}$ dilution of air (open symbols) or fuel (solid symbols). A negative production rate indicates fuel destruction. The dihuent fraction $Z$ is $0.4\left(u_{0}\right.$ $\left.=u_{\mathrm{F}, \mathrm{o}}=\mathbf{u}_{\mathrm{Ox}, \mathrm{o}}=10 \mathrm{~cm} / \mathrm{s}\right)$. 
mole fractions for these flames. Even though the fuel-diluted flame has an $\mathrm{N}_{2}$ concentration of 0.5 at the fuel outlet $(x=0 \mathrm{~cm})$, the $\mathrm{N}_{2}$ mole fraction at the flame front ( $x$ $=1.069 \mathrm{~cm}$ ), defined as the location where the maximum temperature occurs, is $\mathrm{X}_{\mathrm{N} 2}=$ 0.68 for fuel dilution versus $\mathrm{X}_{\mathrm{N} 2}=0.71$ for air dilution. The lower $\mathrm{N}_{2}$ mole fraction with fuel dilution at the flame front is consistent with the higher fuel-diluted flame temperatures observed. Also, we see in Fig. 2.5 the factor of two reduction in the $\mathrm{H}_{2}$ mole fraction at the fuel nozzle $(x=0 \mathrm{~cm})$ that occurs with fuel dilution. Air dilution, on the other hand, causes the oxygen mole fraction at the oxidizer nozzle $(x=2 \mathrm{~cm})$ to drop by only about one third.

Figures 2.6 and 2.7 show the NO mole fractions and NO production rates respectively, $\dot{\omega}_{\text {NO }}$, for the air- and fuel-diluted flames. Note that the NO production rate associated with fuel dilution is on the order of three times larger than the air-dihuted case. Another interesting feature of the $\mathrm{H}_{2}$-air flames is the large diffusional processes occurring here, even though the NO production (cf. Fig. 2.7) is confined to a relatively narrow region in the high temperature flame zone, the NO mole fraction profiles (cf. Fig. 2.6) are very wide.

The reason why FGR is more effective than FIR in lowering the NO emission index in these diluted $\mathrm{H}_{2}$-air flames can be explained by inspecting the NO and fuel production curves, Figs. 2.7 and 2.8 , respectively. The area under the NO production curve represents the total production rate of NO. Similarly, the area under the fuel production curve, negative because fuel is being consumed, is the total production rate of fuel. Note that the emission index (Eqn. 2.14) is the ratio of the NO production integral to 
the fuel consumption integral. Therefore, the larger emission index with fuel dilution is primarily a result of the larger NO production rate (Fig. 2.7), since the fuel production rate

(Fig. 2.8) for fuel dilution, $\dot{\omega}_{\mathrm{Fu}}=-6.099 \times 10^{-5} \mathrm{~mol} / \mathrm{cm}^{2}-\mathrm{s}$, is only slightly less than the fuel production rate with air dilution, $\dot{\omega}_{\mathrm{Fu}}=-6.608 \times 10^{-5} \mathrm{~mol} / \mathrm{cm}^{2}-\mathrm{s}$.

\section{3 $\mathrm{CH}_{4}$-Air Flame Simulation Results}

A wide range of simulations was employed to determine the important factors affecting $\mathrm{NO}_{\mathrm{X}}$ formation in methane-air flames. First, a number of nonreacting isothermal flows were conducted, thus eliminating the complications of chemical kinetics and energy transport, to help understand the counterflow $\mathrm{CH}_{4}$ flames. Next, several fixed inlet velocity cases, similar to the $\mathrm{H}_{2}$-air flames, were performed. The initial velocities of 5 and $50 \mathrm{~cm} / \mathrm{s}$ were half those of the highly reactive $\mathrm{H}_{2}$-air flames. The effect of preheat was then investigated in which the $50 \mathrm{~cm} / \mathrm{s}$ inlet velocity flames were preheated to a reactant temperature of $500 \mathrm{~K}$. Finally, fixed fuel mass flux $\mathrm{CH}_{4}$-air flames were studied. In order to maintain a fixed fuel mass flux condition with the addition of diluent, the inlet velocity of the fuel stream had to be increased as diluent was added. For instance, at a dilution level of $Z=0.15$, the inlet velocity of the fuel stream is $128 \mathrm{~cm} / \mathrm{s}$ compared to the $50 \mathrm{~cm} / \mathrm{s}$ with no dilution. The velocity of the air stream was kept equal to that of the fuel stream in order to prevent any artifactual heat losses through the boundaries. This fixed fuel mass flux condition is most applicable to practice in industrial burners. 


\subsubsection{Nonreacting Isothermal Flow}

The nonreacting flows were conducted with fixed inlet velocities of $u_{0 \mathrm{X}, 0}=u_{\mathrm{F}, \mathrm{o}}=$ $50 \mathrm{~cm} / \mathrm{s}$ (cf. Fig. 2.1) and fixed inlet temperatures of $300 \mathrm{~K}$. Methane was introduced at $\mathrm{x}$ $=0$ and air at $\mathrm{x}=\mathrm{L}$. Conditions for a diluent fraction of $\mathrm{Z}=0.15$, both fuel dilution and air dilution, were investigated to gain some insight into the flow field. These boundary conditions were chosen to match those of certain reacting flows which will be discussed in the following section. Figures 2.9 and 2.10 show the mole fraction profiles through the nonreacting flow field for air and fuel dilution, respectively. The location where methane reaches the stoichiometric value, $X_{\mathrm{CH}_{4}, \mathrm{STOIC}}=0.0794$, is indicated on the figures. Similar to the $\mathrm{H}_{2}$-air flames, fuel dilution causes a decrease in the mole fraction of fuel (Fig. 2.10), $\mathrm{X}_{\mathrm{CH}_{4}}=0.3912$ at the fuel inlet $(\mathrm{x}=0 \mathrm{~cm})$. Even though the change in the $\mathrm{CH}_{4}$ mole fraction is much larger with air dilution (Fig. 2.9), the drop in the $\mathrm{CH}_{4}$ mole fraction from the nozzle concentration $\left(\mathrm{X}_{\mathrm{CH}_{4}}=1.0\right.$ or 0.3912$)$ to the stoichiometric value $\left(\mathrm{X}_{\mathrm{CH}_{4}, \text { STOIC }}=\right.$ 0.0794) occurs over a greater distance. The significance of this observation will be clarified when we examine the velocity fields associated with these two flows.

Figure 2.11 shows the velocity profiles throughout the entire flow field for the airand fuel-diluted flames $(Z=0.15)$. A positive velocity indicates a flow from left to right, while a negative velocity indicates flow from right to left. The boundary conditions of both streams require that the inlet velocities be fixed at $50 \mathrm{~cm} / \mathrm{s}$. The location of the stagnation plane is shifted to the right with the addition of diluent to the fuel stream. This shifting of the stagnation plane can be understood by investigating the increase in 


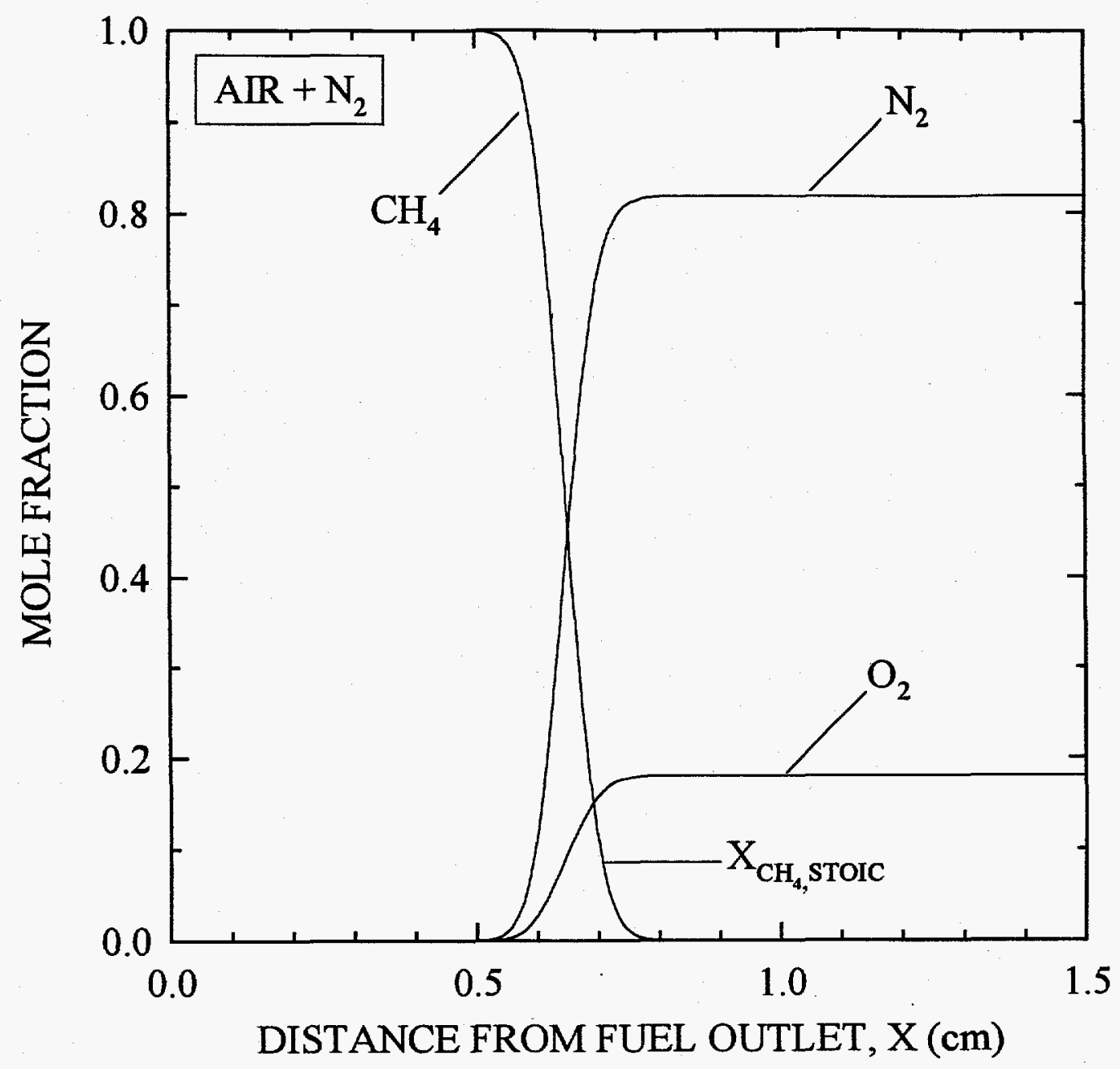

FIGURE 2.9. Mole fraction profiles for nonreacting $(300 \mathrm{~K})$ counterflow. Pure $\mathrm{CH}_{4}$ flows from the left $(x=0)$ and $N_{2}$-diluted air flows from the right $(x=L)$. The $N_{2}$-diluent fraction is $Z=0.15$ and $u_{0}=u_{L}=50 \mathrm{~cm} / \mathrm{s}$. 


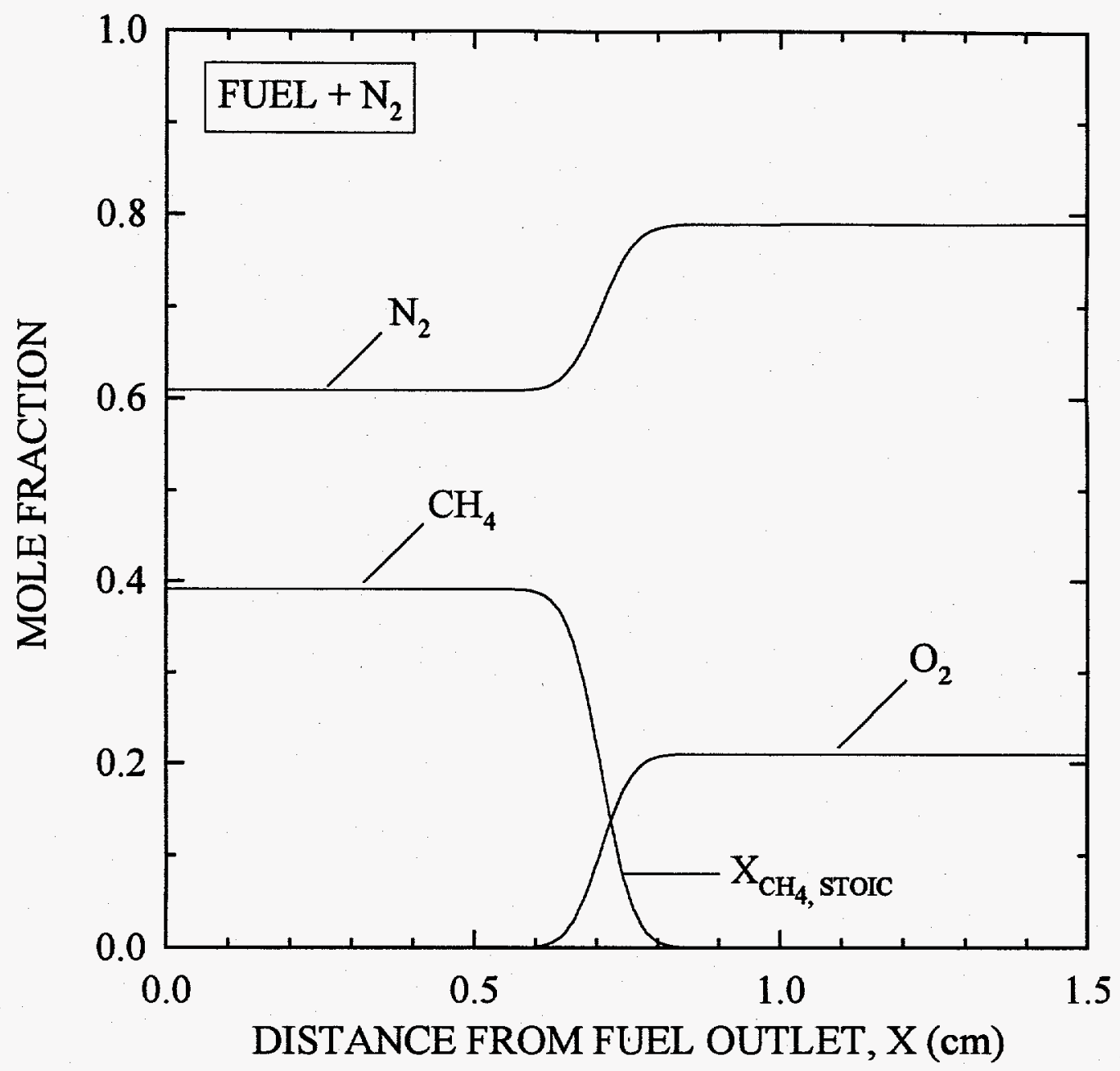

FIGURE 2.10. Mole fraction profiles for nonreacting ( $300 \mathrm{~K}$ ) counterflow. Diluted $\mathrm{CH}_{4}$ mixture flows from the left $(x=0)$ and air flows from the right $(x=L)$. The $\mathrm{N}_{2}$-diluent fraction is $\mathrm{Z}=0.15$ and $\mathrm{u}_{\mathrm{o}}=\mathrm{u}_{\mathrm{L}}=50 \mathrm{~cm} / \mathrm{s}$. 


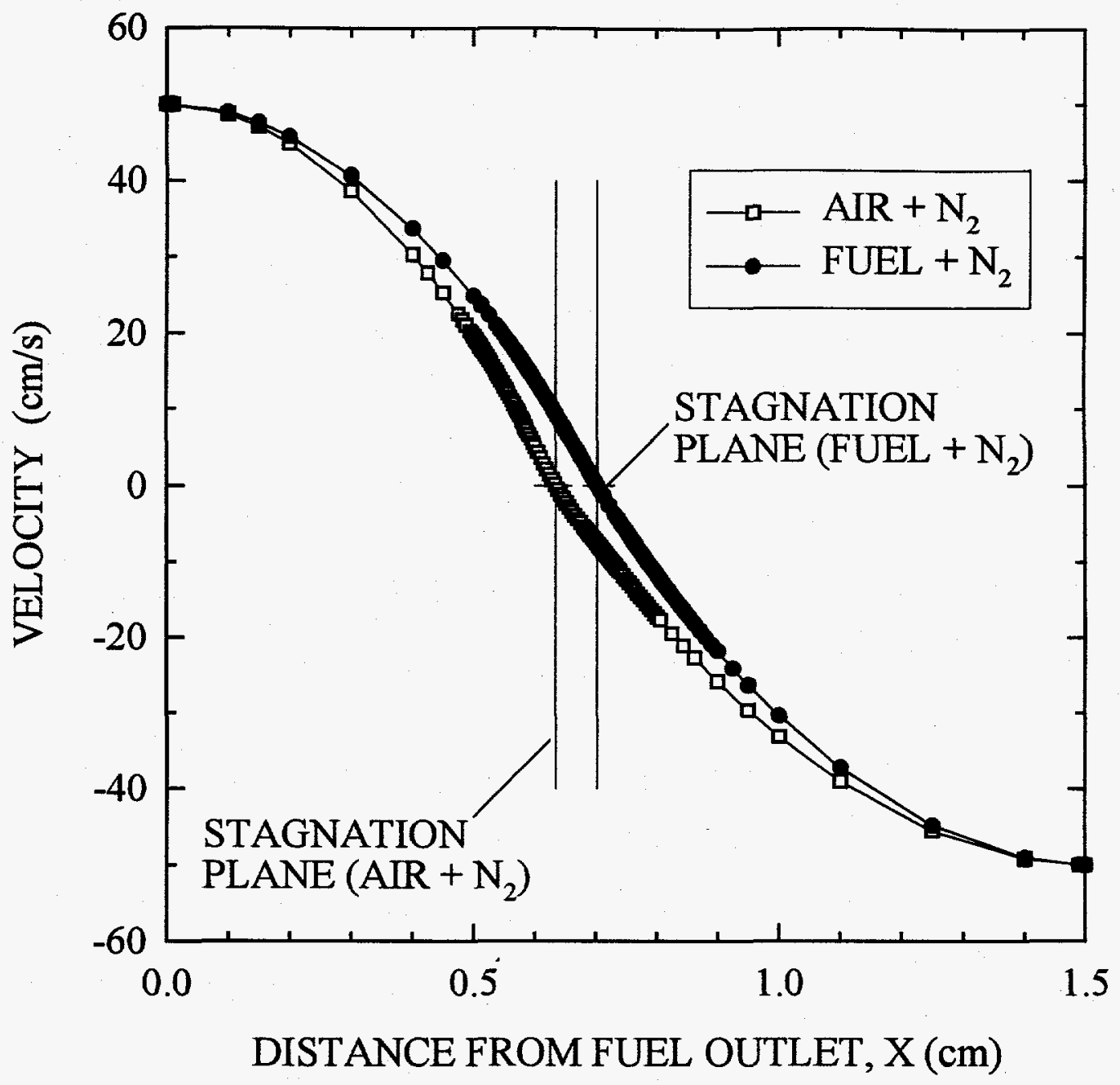

FIGURE 2.11. Velocity profiles for nonreacting counterflows corresponding to Figs. 2.8 and 2.9. The stagnation plane for the $\mathrm{N}_{2}$-diluted $\mathrm{CH}_{4}$ case is shifted to the right because of the greater momentum flux associated with the $\mathrm{N}_{2}-\mathrm{CH}_{4}$ mixture compared to the undiluted $\mathrm{CH}_{4}$. 
momentum flux of the fuel stream with the addition of diluent. Table 2.1 shows the mass and momentum fluxes at the nozzles for no dilution, fuel dilution, and air dilution. The addition of $\mathrm{N}_{2}$ to the fuel stream causes a large increase in the density of the flow issuing from the fuel nozzle. As a result, there is a substantial increase in the momentum flux of the diluted fuel stream, even though the inlet velocity remains fixed, which explains the observed shifting of the stagnation plane away from the fuel exit. If the momentum flux of the fuel and air streams were equal, the stagnation plane would lie halfway between the two nozzles $(x=0.75 \mathrm{~cm})$; however, the stagnation plane is always located to the left of center since the fuel stream momentum flux is always less than the air stream momentum flux. The addition of $\mathrm{N}_{2}$ to the air stream barely affects the density of the diluted air mixture, thus the momentum flux of the air stream remains essentially constant.

TABLE 2.1. $\mathrm{N}_{2}$ Mass Fraction, Mixture Density, Mixture Mass Flux, and Mixture Momentum Flux for Pure and $\mathrm{N}_{2}$-Diluted $(\mathrm{Z}=0.15)$ Fuel and Air Streams $(T=300 \mathrm{~K})$.

\begin{tabular}{lcccc}
\hline & \multicolumn{4}{c}{ Flow Stream } \\
\cline { 2 - 5 } Parameter & $\mathrm{CH}_{4}$ & $\mathrm{CH}_{4}+\mathrm{N}_{2}$ & Air & Air $+\mathrm{N}_{2}$ \\
\hline $\mathrm{N}_{2}$ Mass Fraction, $\mathrm{Y}_{\mathrm{N}_{2}}$ & 0 & 0.731 & 0.767 & 0.799 \\
Density, $\rho\left(\mathrm{kg} / \mathrm{m}^{3}\right)$ & 0.652 & 0.948 & 1.133 & 1.128 \\
Mass Flux, $\rho v\left(\mathrm{~kg} / \mathrm{m}^{2}-\mathrm{s}\right)$ & 0.326 & 0.474 & 0.567 & 0.564 \\
Momentum Flux, $\rho v^{2}\left(\mathrm{~N} / \mathrm{m}^{2}\right)$ & 0.163 & 0.237 & 0.284 & 0.282 \\
\hline
\end{tabular}


Figures 2.12 and 2.13 show the $\mathrm{CH}_{4}$ mole fraction and the velocity profiles, respectively, referenced from the location of the stagnation plane. The stoichiometric mole fraction, $\mathbf{X}_{\mathrm{CH}_{4}, \text { STOIC }}$, occurs much closer to the stagnation plane with fuel dilution. In

Fig. 2.13, we clearly see that $\mathrm{X}_{\mathrm{CH} a, \mathrm{STOC}}$ occurs in a lower velocity region with fuel dilution. Since the velocities at $\mathbf{X}_{\mathrm{CH}, \text { STOIC }}$ are lower with fuel dilution, the corresponding residence times at high temperature will be larger. This same behavior will be seen in the reacting $\mathrm{CH}_{4}$ flames that follow. The longer residence times associated with fuel dilution are an important factor contributing to NO production.

\subsubsection{Reacting Flows}

The first set of studies conducted with $\mathrm{CH}_{4}$-air flames are essentially the same as those described previously for the $\mathrm{H}_{2}$-air flames except that the initial velocities (5 and 50 $\mathrm{cm} / \mathrm{s}$ ) were half those of the $\mathrm{H}_{2}$-air calculations. The fixed inlet velocity flames of $50 \mathrm{~cm} / \mathrm{s}$ correspond to the nonreacting isothermal flows presented previously. The maximum diluent fraction obtained with the $\mathrm{CH}_{4}$-air flames was $\mathrm{Z}=0.37$, which is significantly smaller than the highly reactive $\mathrm{H}_{2}$-air dilution level achieved. The maximum achievable diluent fraction, $\mathrm{Z}$, is based on lack of convergence of the flame code. In addition to the fixed velocity flames, fuel dilution with a fixed fuel mass flux is also investigated in detail and the results are presently simultaneously with the fixed velocity cases. The effect of temperatures, residence times, and $\mathrm{CH}_{4}$ and $\mathrm{NO}$ molar production rates on the NO emission indices in the air-diluted and fuel-diluted flames are presented and discussed in 


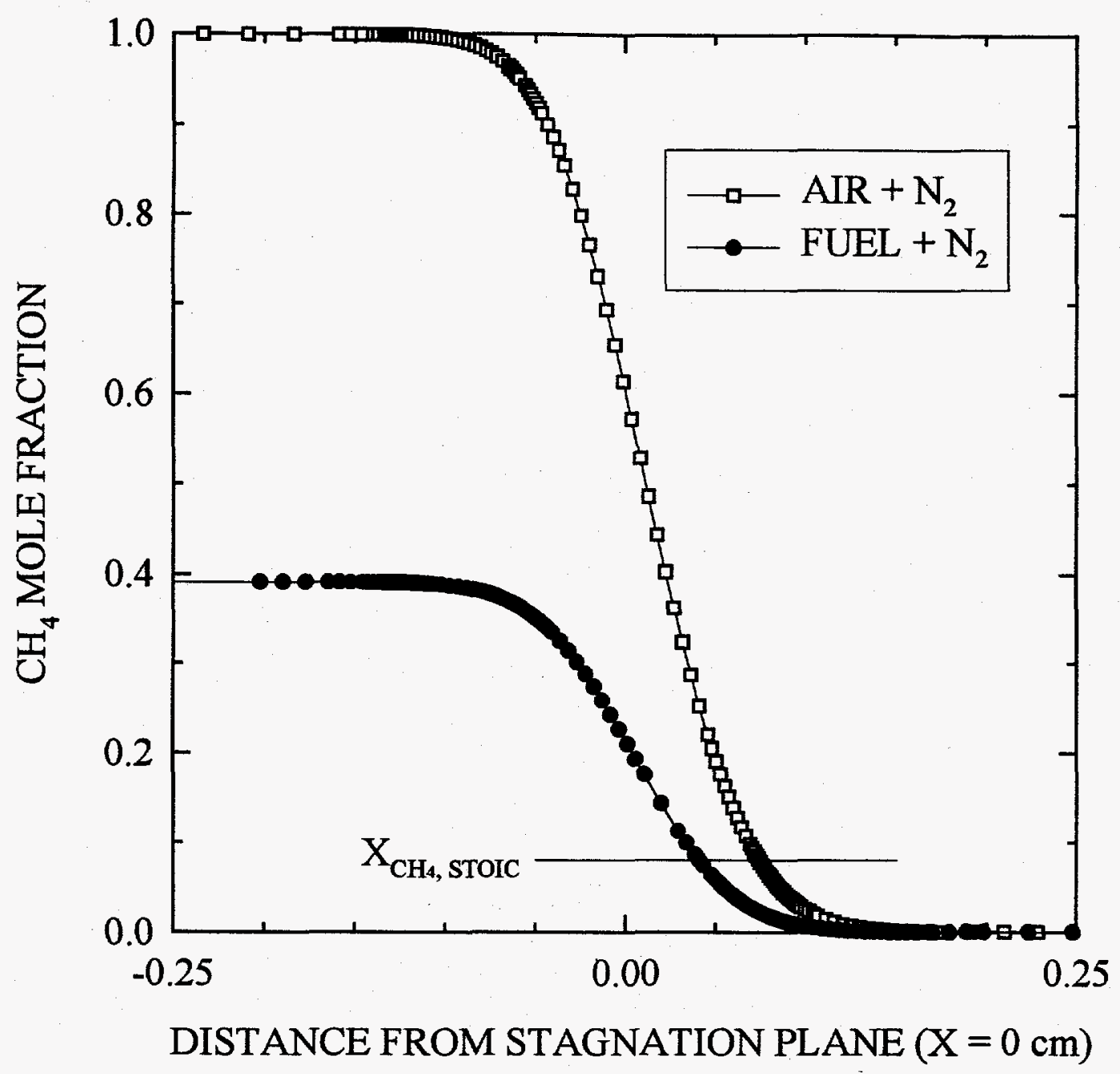

FIGURE 2.12. $\mathrm{CH}_{4}$ mole fraction profiles from Figs. 2.8 and 2.9 plotted as functions of the distance from the stagnation plane. Also indicated is the stoichiometric $\mathrm{CH}_{4}$ mole fraction $(=0.0794)$ for these $\mathrm{N}_{2}$-diluted mixtures. 


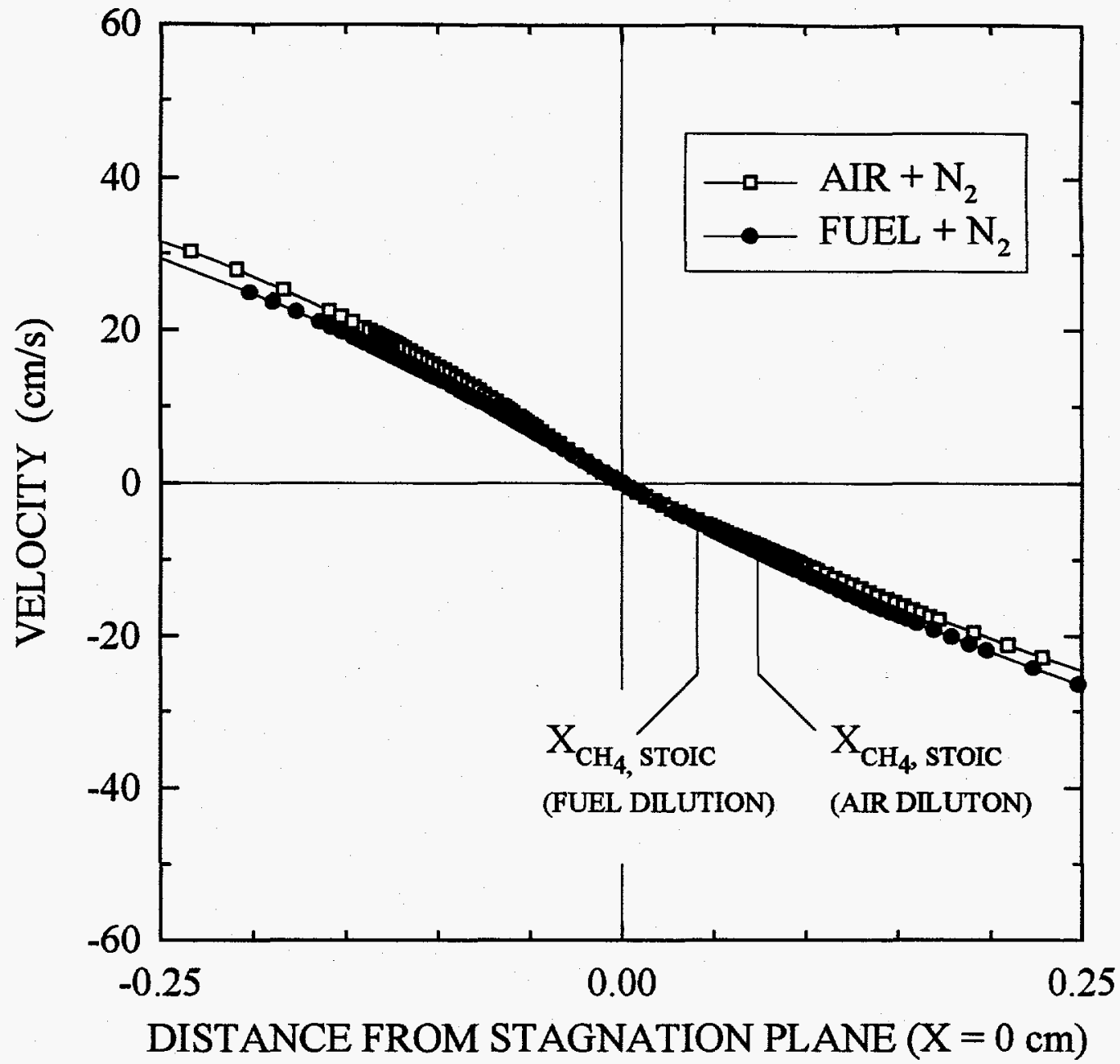

FIGURE 2.13. Velocity profiles for nonreacting counterflows with either the fuel or air stream diluted with $\mathrm{N}_{2}(Z=0.15)$ where the origin of the axial distance coordinate is the stagnation plane. 
detail Finally, parametric studies are presented to further investigate the effect of reactant preheat on NO emissions.

\subsubsection{Flow and Flame Structure}

Figures 2.14 and 2.15 show the NO emission index versus the diluent fraction, $Z$, for the 5 and $50 \mathrm{~cm} / \mathrm{s}$ fixed inlet velocity flames, respectively. As with the $\mathrm{H}_{2}$-air flames, for equivalent diluent fraction, $Z$, air dilution is more effective than fuel dilution contrary to the results of full-scale FIR experiments [1, 24]. However, the factors contributing to the differences in NO emission indices observed are not the same as those for the $\mathrm{H}_{2}$-air flames. These factors will be explained in more detail in the results that follow.

The factors observed to affect the NO formation in the $5 \mathrm{~cm} / \mathrm{s}$ and $50 \mathrm{~cm} / \mathrm{s}$ fixed velocity flames were identical; therefore, detailed results will be presented for the $50 \mathrm{~cm} / \mathrm{s}$ flames only. In addition to presenting these results, it is very useful to simultaneously study the fixed fuel mass flux case in order to elucidate the fundamental differences affecting NO emission indices between the fixed velocity and fixed fuel mass flux simulations. Table 2.2 shows the test conditions for the $\mathrm{CH}_{4}$-air flames of interest. The nitrogen diluent fraction, $Z$, was either zero, no dilution, or $Z=0.15$, and the reactant temperature was maintained at $300 \mathrm{~K}$ for all cases. 


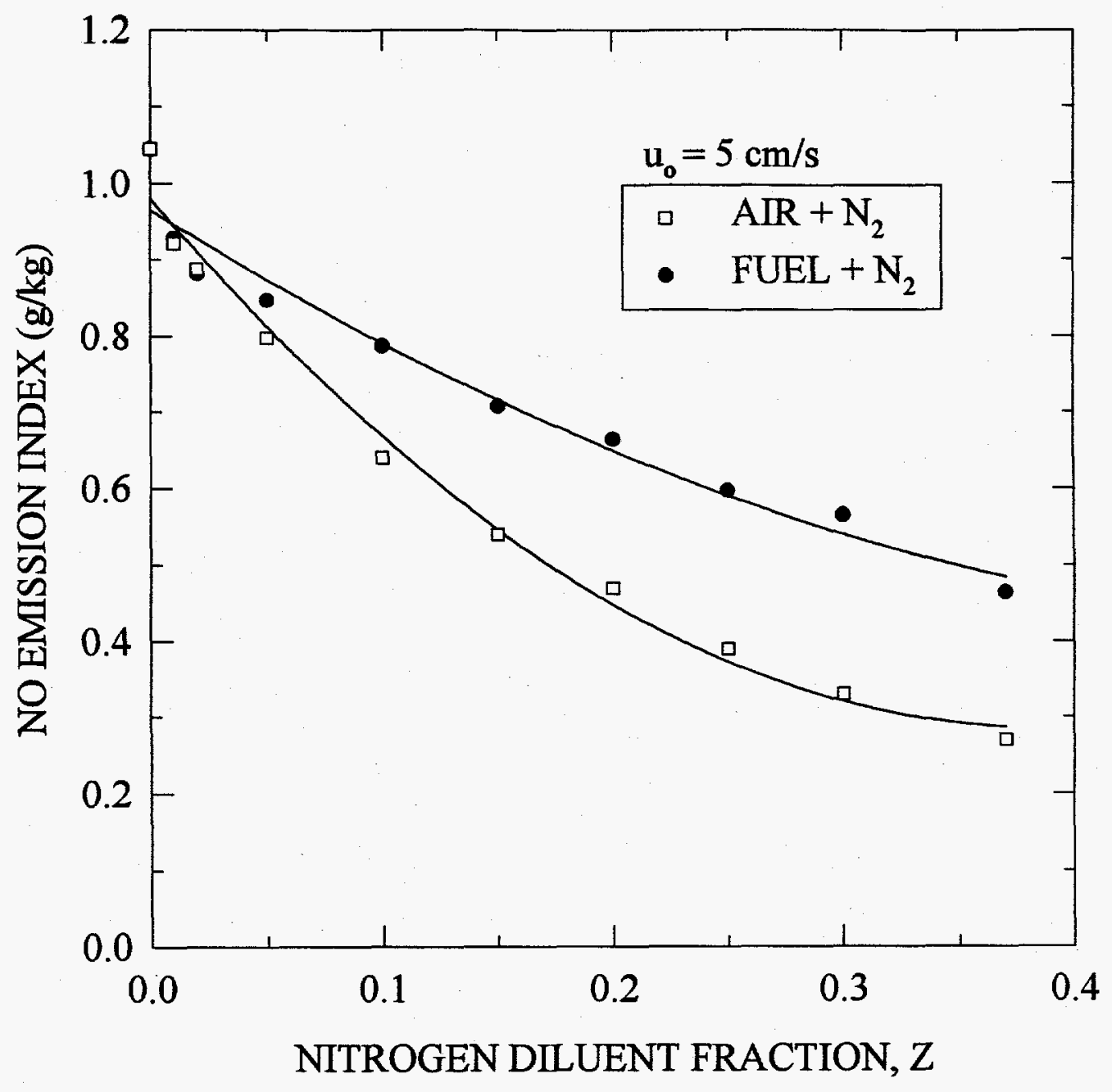

FIGURE 2.14. Calculated effect of $\mathrm{N}_{2}$ dilution on $\mathrm{NO}$ emission indices of $\mathrm{CH}_{4}$-air counterflow flames in which the $\mathrm{N}_{2}$ has been added to either the air or fuel streams $\left(u_{0}=u_{F, o}=u_{0 x, 0}=5 \mathrm{~cm} / \mathrm{s}\right)$. Reactants enter at $300 \mathrm{~K}$. 


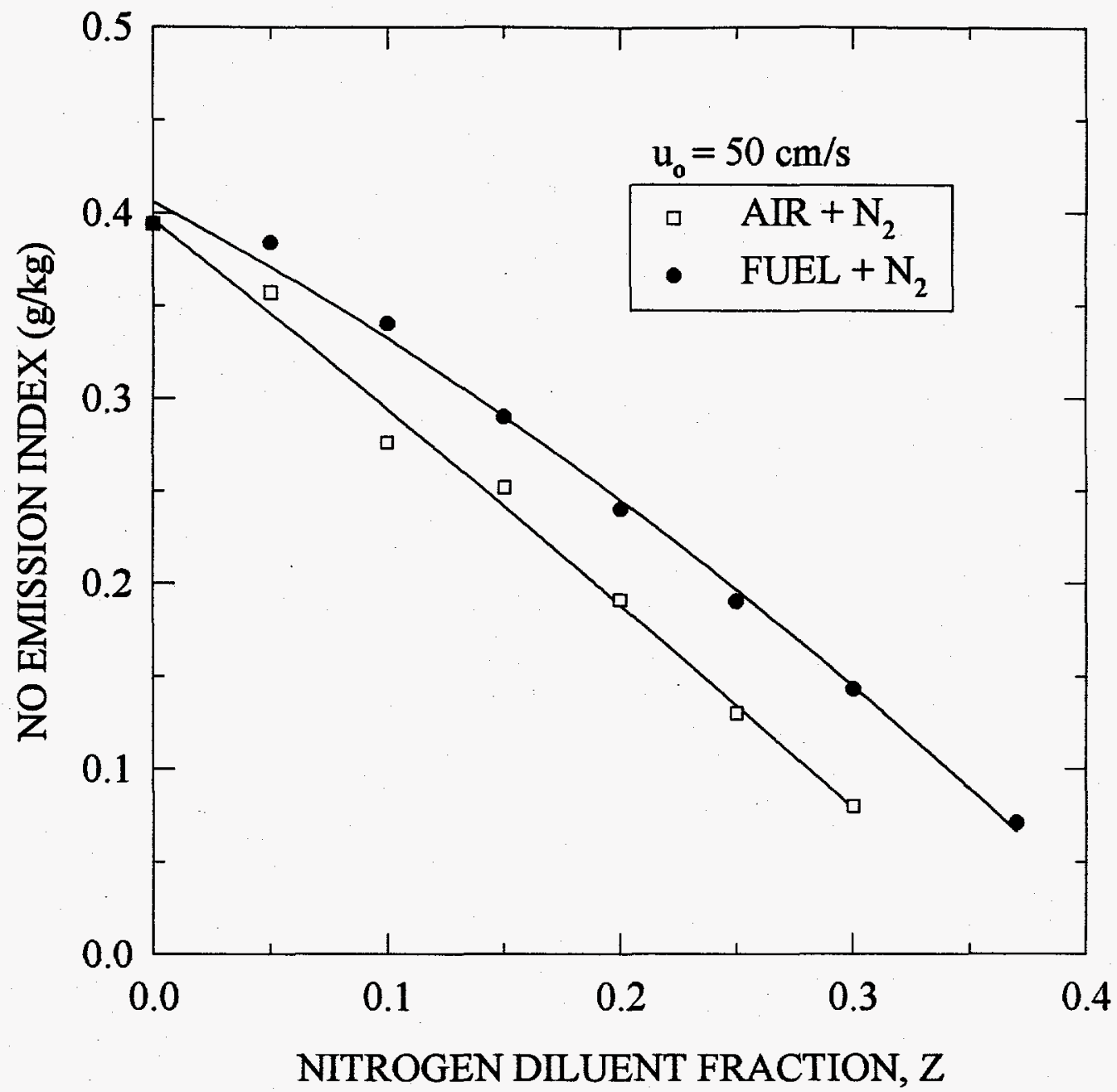

FIGURE 2.15. Calculated effect of $\mathrm{N}_{2}$ dilution on $\mathrm{NO}$ emission indices of $\mathrm{CH}_{4}$-air counterflow flames in which the $\mathrm{N}_{\mathbf{2}}$ has been added to either the air or fuel streams $\left(u_{0}=u_{F, 0}=u_{0,0}=50 \mathrm{~cm} / \mathrm{s}\right)$. Reactants enter at $300 \mathrm{~K}$. 
TABLE 2.2. Test Conditions for Selected Numerical Simulations of $\mathrm{CH}_{4}$-Air Counterflow Diffusion Flames with Reactants at $300 \mathrm{~K}$.

\begin{tabular}{ccccc}
\hline $\begin{array}{c}\text { Case } \\
\text { No. }\end{array}$ & $\begin{array}{c}\text { Reactant } \\
\text { Velocity }(\mathrm{cm} / \mathrm{s})\end{array}$ & $\begin{array}{c}\text { Methane } \\
\text { Mass Flux }\left(\mathrm{kg} / \mathrm{s}^{\left.-\mathrm{m}^{2}\right)}\right.\end{array}$ & $\begin{array}{c}\mathbf{N}_{2} \text { Diluent Fraction, Z } \\
\text { Fuel Side }\end{array}$ & $\underline{\underline{\text { Air Side }}}$ \\
\hline 1 & 50 & 0.326 & 0 & 0 \\
2 & 50 & 0.326 & 0 & 0.15 \\
3 & 50 & 0.106 & 0.15 & 0 \\
4 & 127.8 & 0.326 & 0.15 & 0 \\
\hline
\end{tabular}

Figures 2.16, 2.17, and 2.18 show the reactant $\left(\mathrm{CH}_{4}, \mathrm{~N}_{2}, \mathrm{O}_{2}\right)$ mole fraction profiles for the fixed inlet velocity undiluted, air-diluted, and fuel-diluted flames (Cases 1 - 3, Table 2.2), respectively. The primary difference between the reacting flows (cf. Figs. 2.17 and 2.18) and the corresponding, $Z=0.15$, nonreacting flows (cf. Figs. 2.9 and 2.10) is the disappearance of the large overlapping region where $\mathrm{CH}_{4}$ and $\mathrm{O}_{2}$ coexist in the nonreacting flows. This is to be expected since the fuel and oxidizer are rapidly consumed at the flame front.

Figure 2.19 shows the reactant profiles for the fixed fuel mass flux flame (Case 4, $Z=0.15$ ) having the same fuel mass flux as the undiluted flame (Case $1, Z=0$ ). The fixed inlet velocity fuel-diluted flame (Case $3, Z=0.15$ ) and the fixed fuel mass flux flame have nominally the same flame structure; however, we see that the reaction zone is much narrower with the fixed fuel mass flux flame. This is to be expected since the reactant 


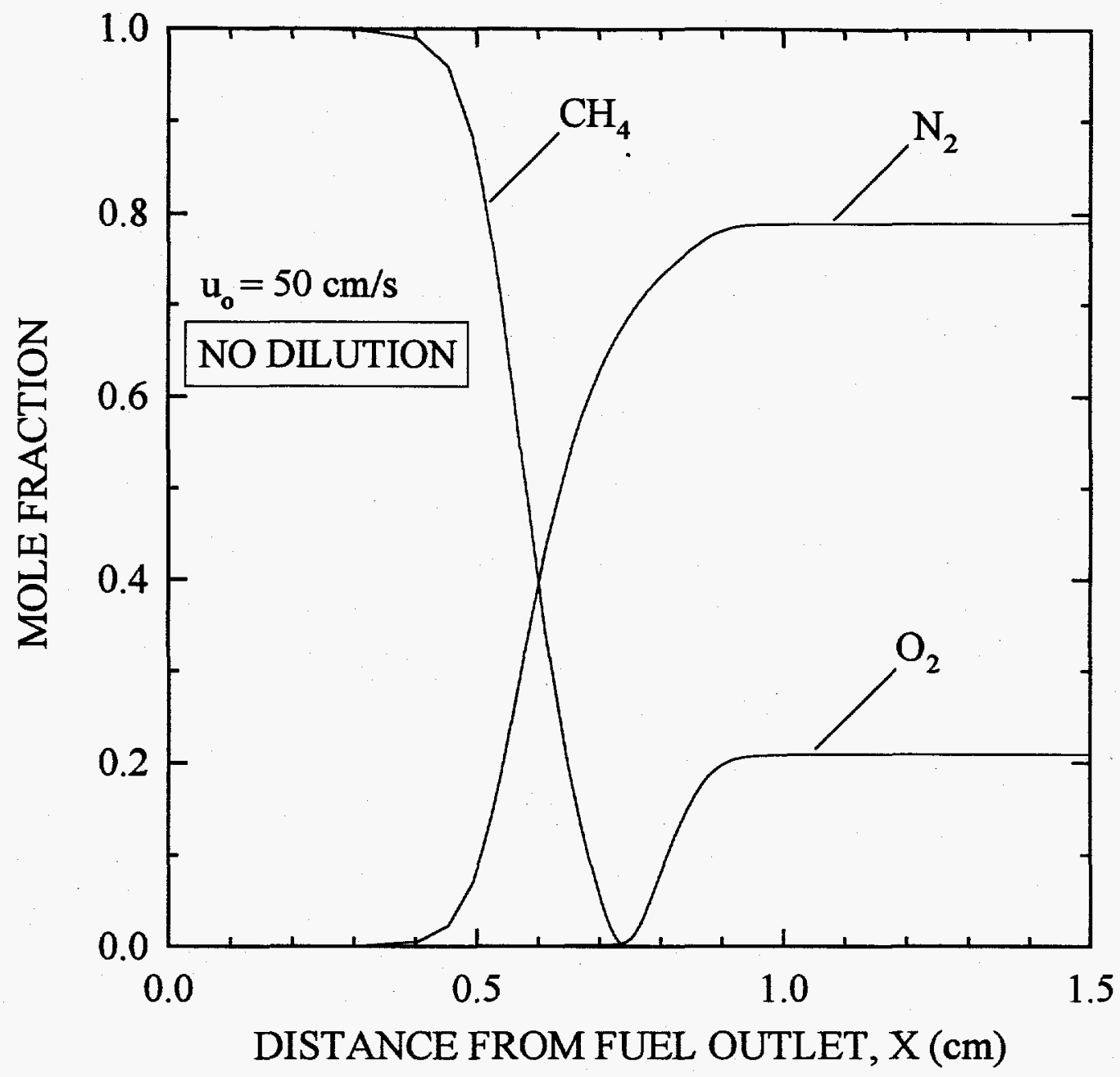

FIGURE 2.16. Methane, oxygen, and nitrogen mole fraction profiles for undiluted counterflow diffusion flame (Case 1). Reactants enter at $300 \mathrm{~K}$ with velocities of $50 \mathrm{~cm} / \mathrm{s}$ at $x=0$ and $x=1.5 \mathrm{~cm}$. 


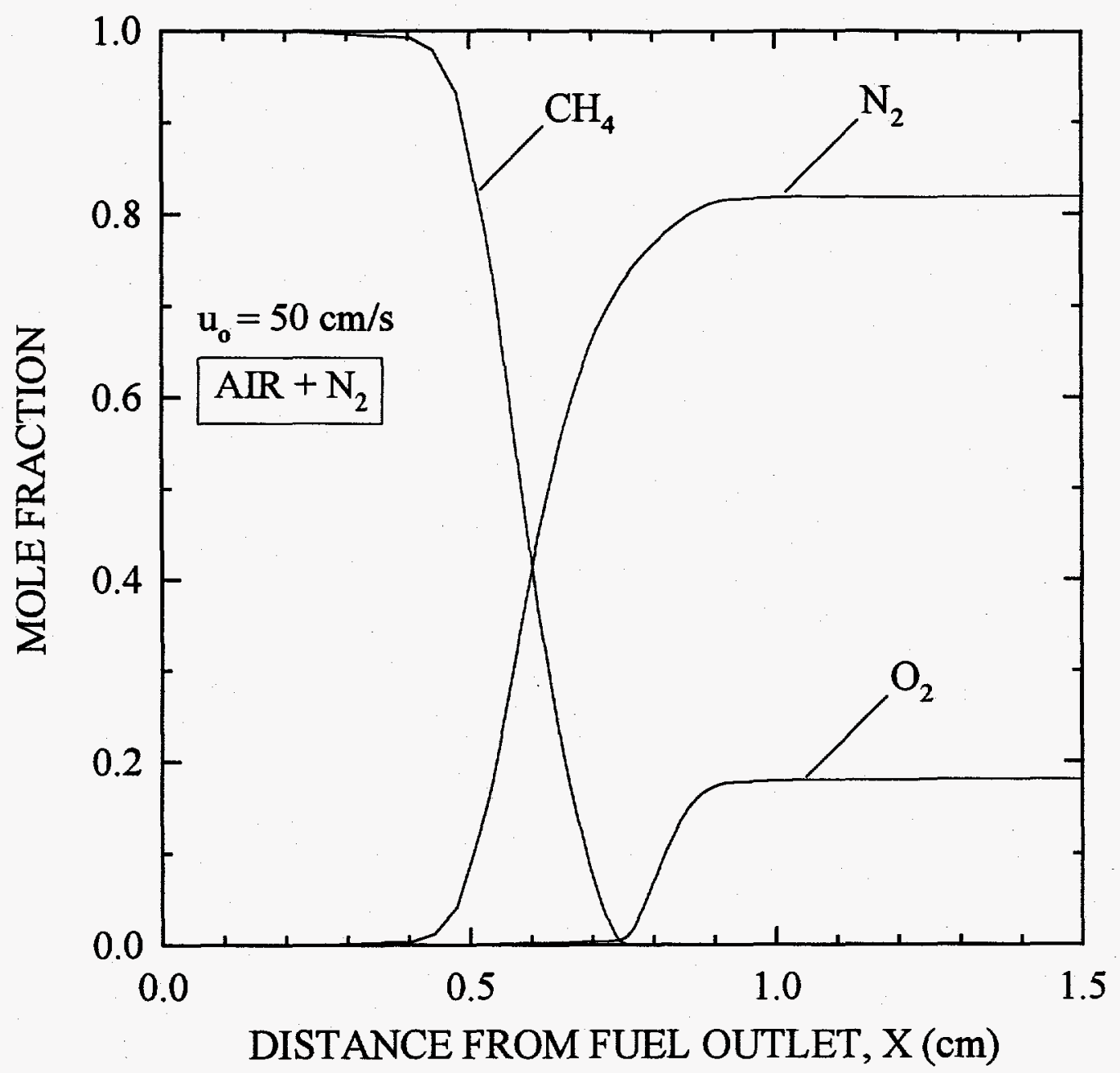

FIGURE 2.17. Methane, oxygen, and nitrogen mole fraction profiles for a counterflow diffusion flame with the air stream diluted with $\mathrm{N}_{2}(Z=0.15)$ (Case 2). Reactants enter at $300 \mathrm{~K}$ with velocities of $50 \mathrm{~cm} / \mathrm{s}$ at $x=0$ and $x=1.5$ $\mathrm{cm}$. 


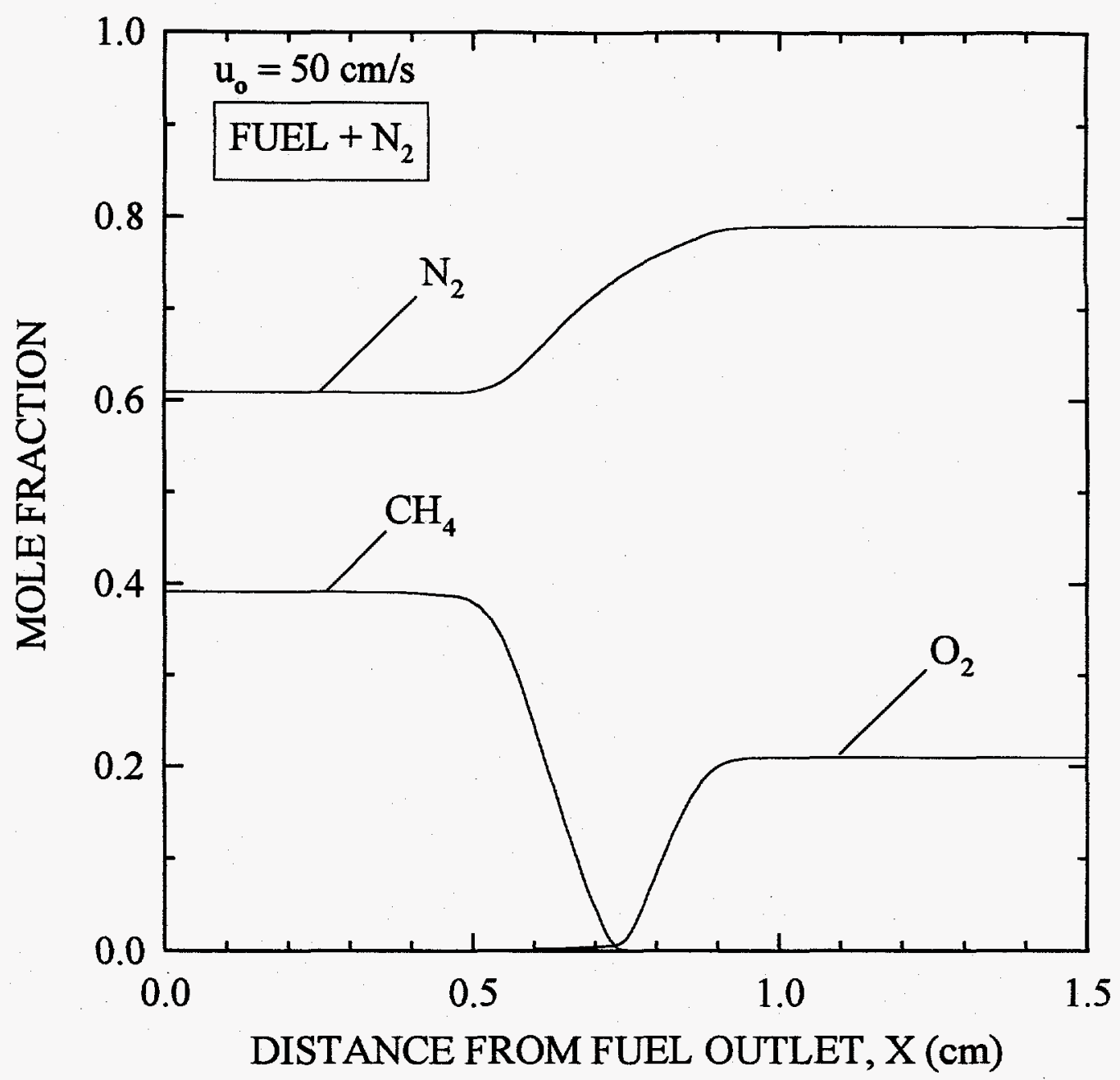

FIGURE 2.18. Methane, oxygen, and nitrogen mole fraction profiles for a counterflow diffusion flame with the fuel stream diluted with $\mathrm{N}_{2}(Z=0.15)$ (Case 3). Reactants enter at $300 \mathrm{~K}$ with velocities of $50 \mathrm{~cm} / \mathrm{s}$ at $x=0$ and $x=1.5$ cm. 


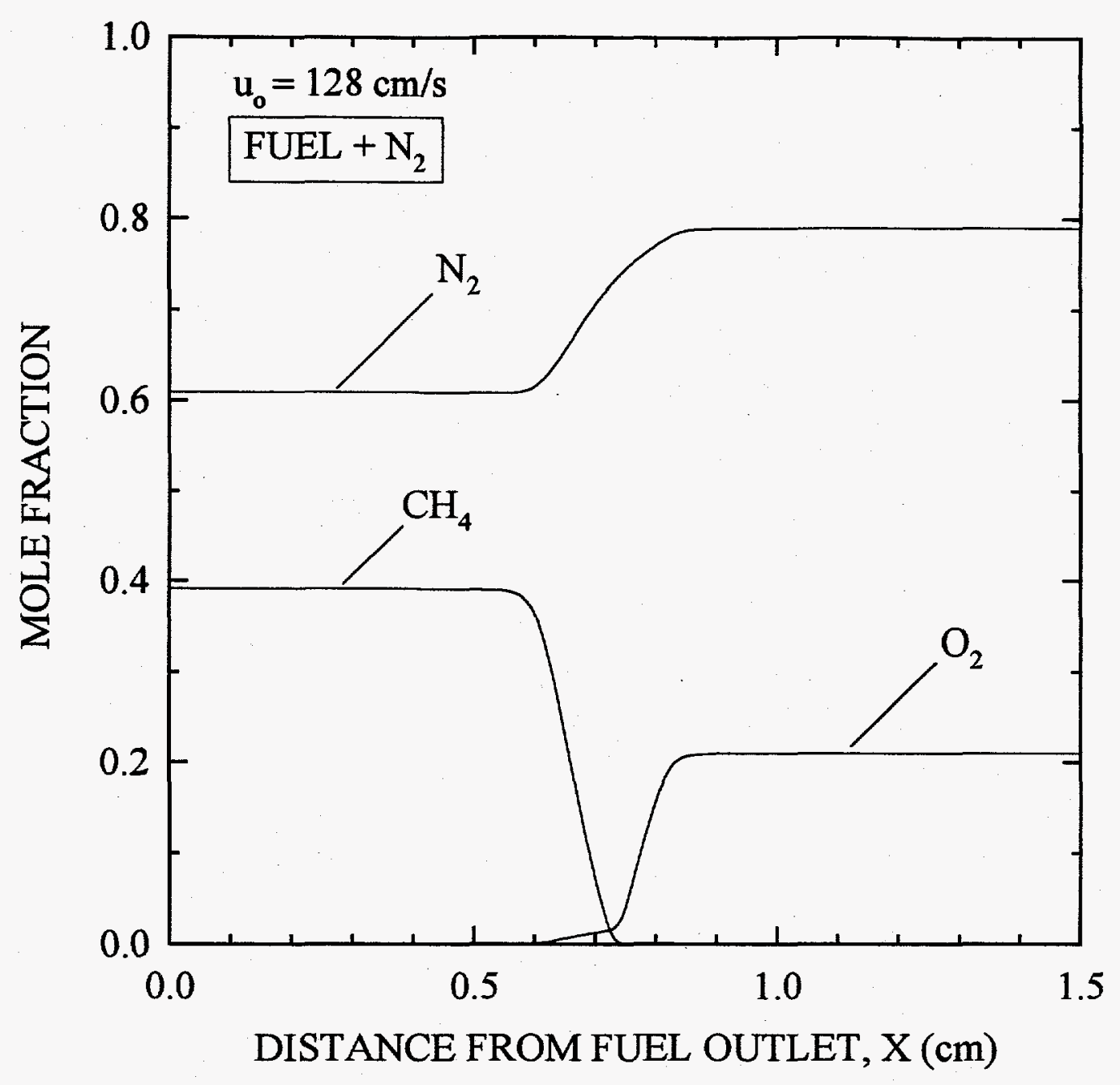

FIGURE 2.19. Methane, oxygen, and nitrogen mole fraction profiles for a counterflow diffusion flame with fuel dilution $(Z=0.15)$ (Case 4). The fuel mass flux is identical to the undiluted flame (Fig. 2.15) thus requiring the inlet velocities to be higher. Reactants enter at $300 \mathrm{~K}$ with velocities of 128 $\mathrm{cm} / \mathrm{s}$ at $x=0$ and $x=1.5 \mathrm{~cm}$. 
inlet velocities have increased by roughly 2.5 times. Finally, Fig. 2.19 shows a small region where $\mathrm{CH}_{4}$ and $\mathrm{O}_{2}$ coexist. This is a result of the increased velocity causing the characteristic flow times to approach that of the characteristic chemical reaction times.

The temperature profiles for cases 1-3 are shown in Fig. 2.20. Here we see the addition of diluent effectively reduces the peak flame temperatures; however, unlike the $\mathrm{H}_{2}$-air flames, the reduction in flame temperatures is roughly equal for fuel and air dilution. Therefore, the factors affecting NO formation are different in the fixed velocity $\mathrm{CH}_{4}$-air flames. Figure 2.21 shows the velocity profiles for cases 1-3. The temperature profile for Case 4, fixed fuel mass flux, is given in Fig. 2.22, and the corresponding velocity profile is shown in Fig. 2.23, along with the profile for the other fuel-diluted flame (Case 3) for comparison.

A key to understanding NO formation is the time-temperature relationship for gases flowing through the flame zone. Therefore, we define a residence time as the time a fluid particle exists above $1500 \mathrm{~K}$. The choice of $1500 \mathrm{~K}$ is somewhat arbitrary, but is a reasonable lower limit for NO formation. The $1500 \mathrm{~K}$ level is shown in the temperature profiles for the $\mathrm{CH}_{4}$ flames (cf. Figs. 2.20 and 2.22). This residence time is calculated by integrating the reciprocal of the velocity from the axial location where the temperature first reaches $1500 \mathrm{~K}$, through the peak, and terminating the calculation at the axial location where the temperature falls to $1500 \mathrm{~K}$, i.e.,

$$
\text { Residence time, } \tau \equiv \int_{\mathrm{x}_{1}(\mathrm{~T}=1500 \mathrm{~K})}^{\mathrm{x}_{2}(\mathrm{~T}=1500 \mathrm{~K})} \text {. }
$$




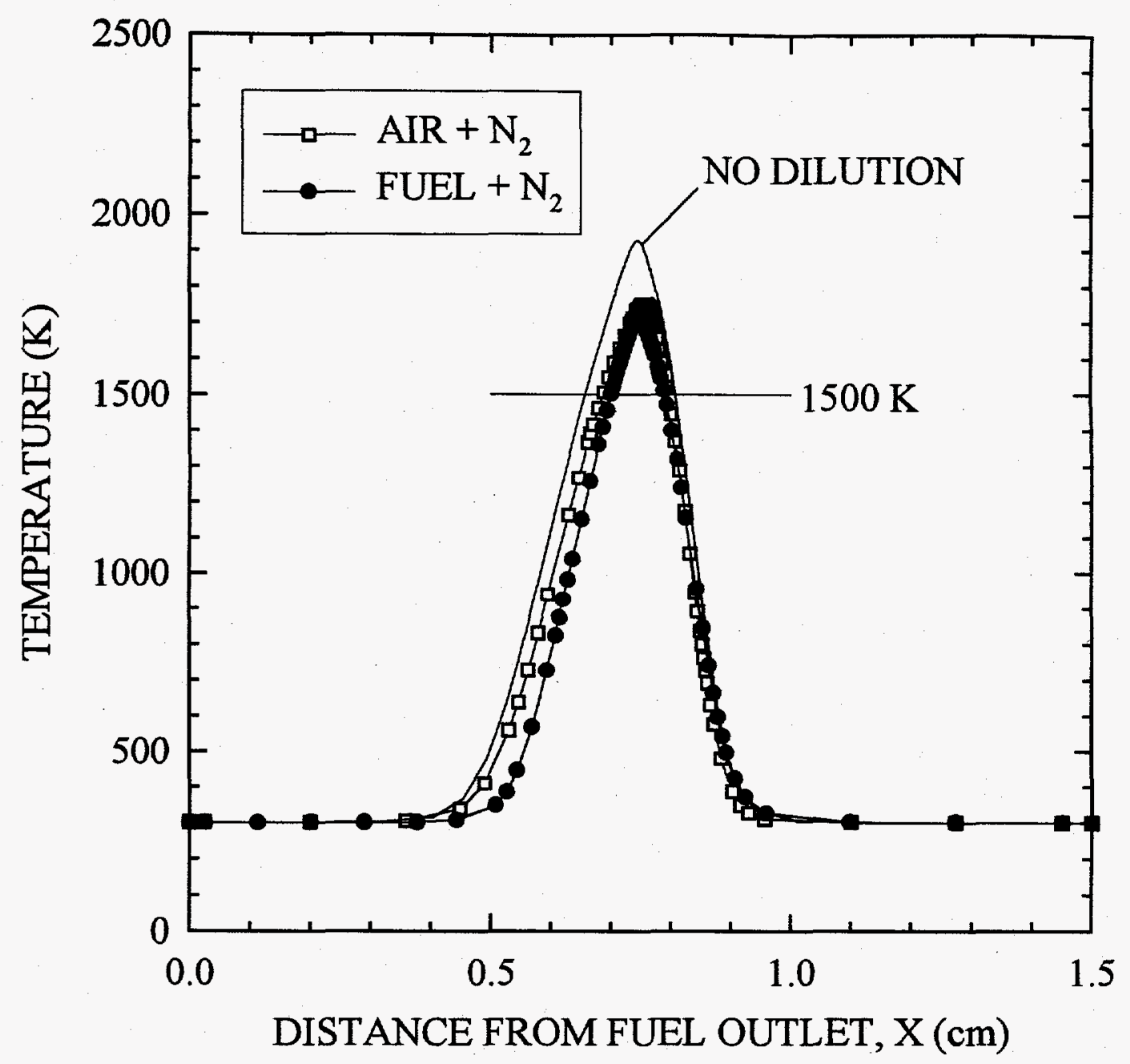

FIGURE 2.20. Temperature profiles for counterflow diffusion flames with no dilution (Case 1), the air stream diluted with $\mathrm{N}_{2}$ for $\mathrm{Z}=0.15$ (Case 2), and the fuel stream diluted with $N_{2}$ for $Z=0.15$ (Case 3). Reactants enter at $300 \mathrm{~K}$ with velocities of $50 \mathrm{~cm} / \mathrm{s}$ at $x=0$ and $x=1.5 \mathrm{~cm}$. 


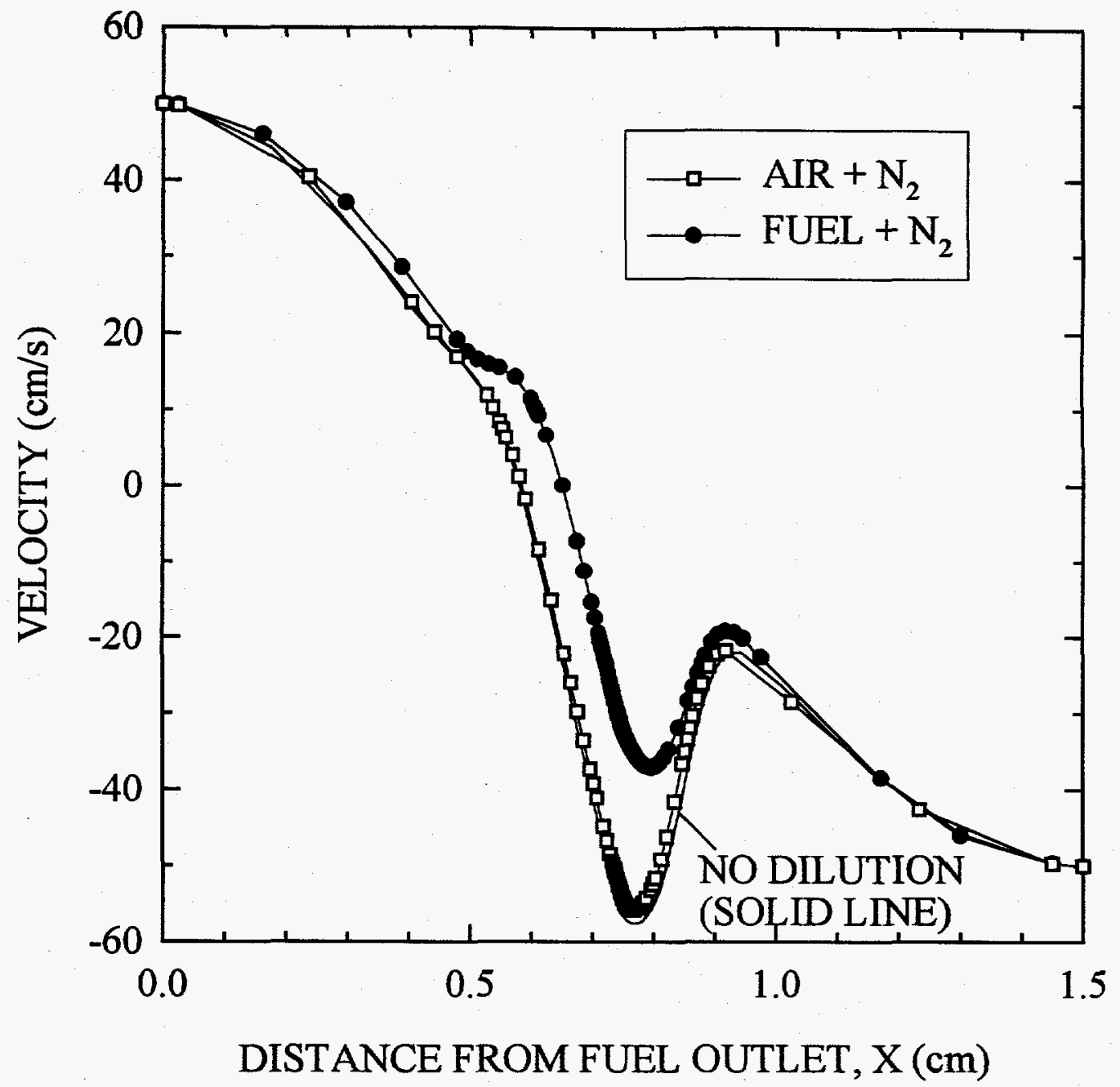

FIGURE 2.21. Velocity profiles for counterflow diffusion flames with the air stream diluted with $\mathrm{N}_{2}$ for $Z=0.15$ (Case 2), and the fuel stream diluted with $\mathrm{N}_{2}$ for $Z=0.15$ (Case 3). 


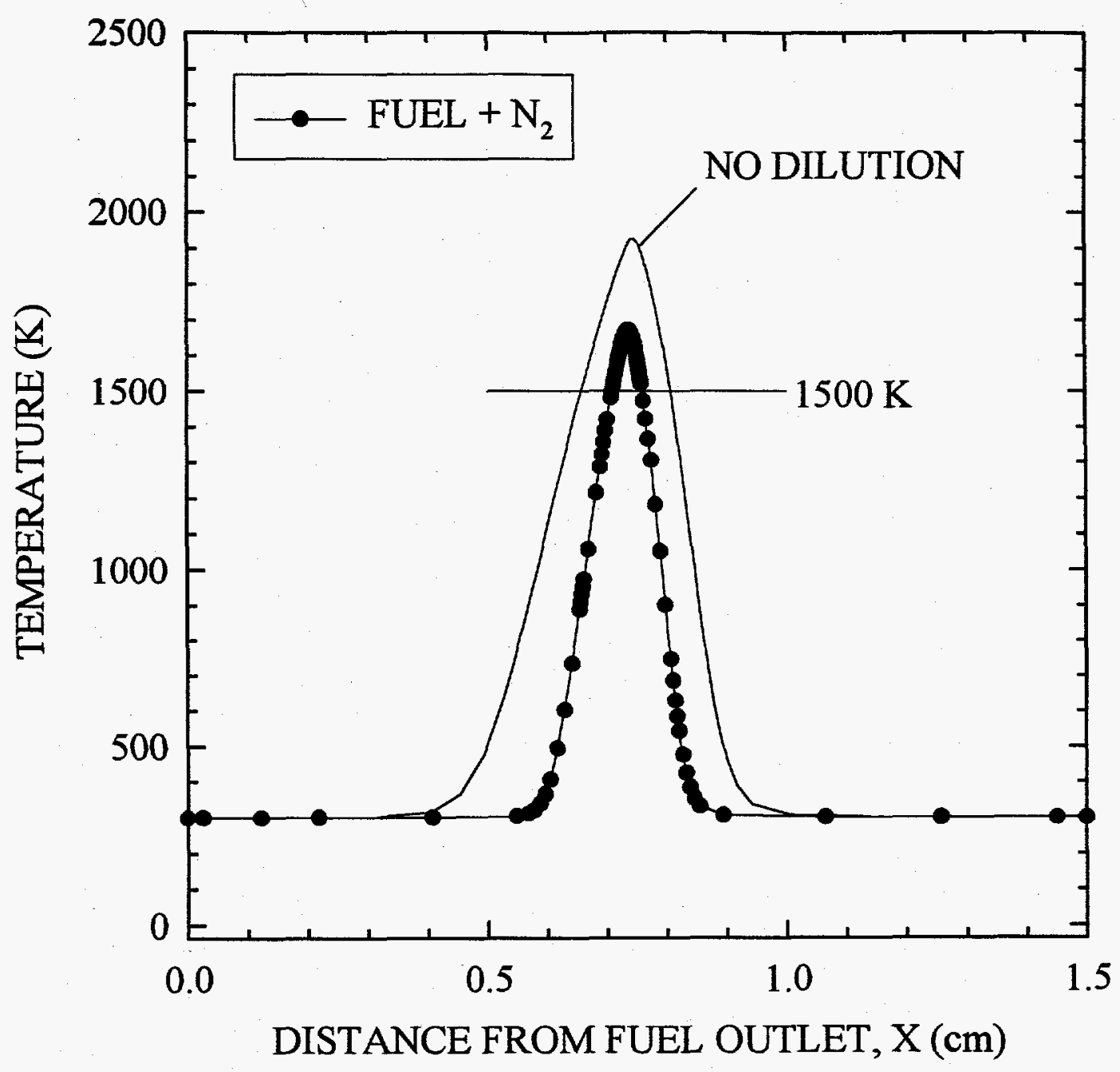

FIGURE 2.22. Temperature profile for counterflow diffusion flames with fuel stream diluted with $\mathrm{N}_{2}$ for $Z=0.15$ (Case 4). Reactants enter at $300 \mathrm{~K}$ with velocities of $128 \mathrm{~cm} / \mathrm{s}$ at $x=0$ and $x=1.5 \mathrm{~cm}$ 


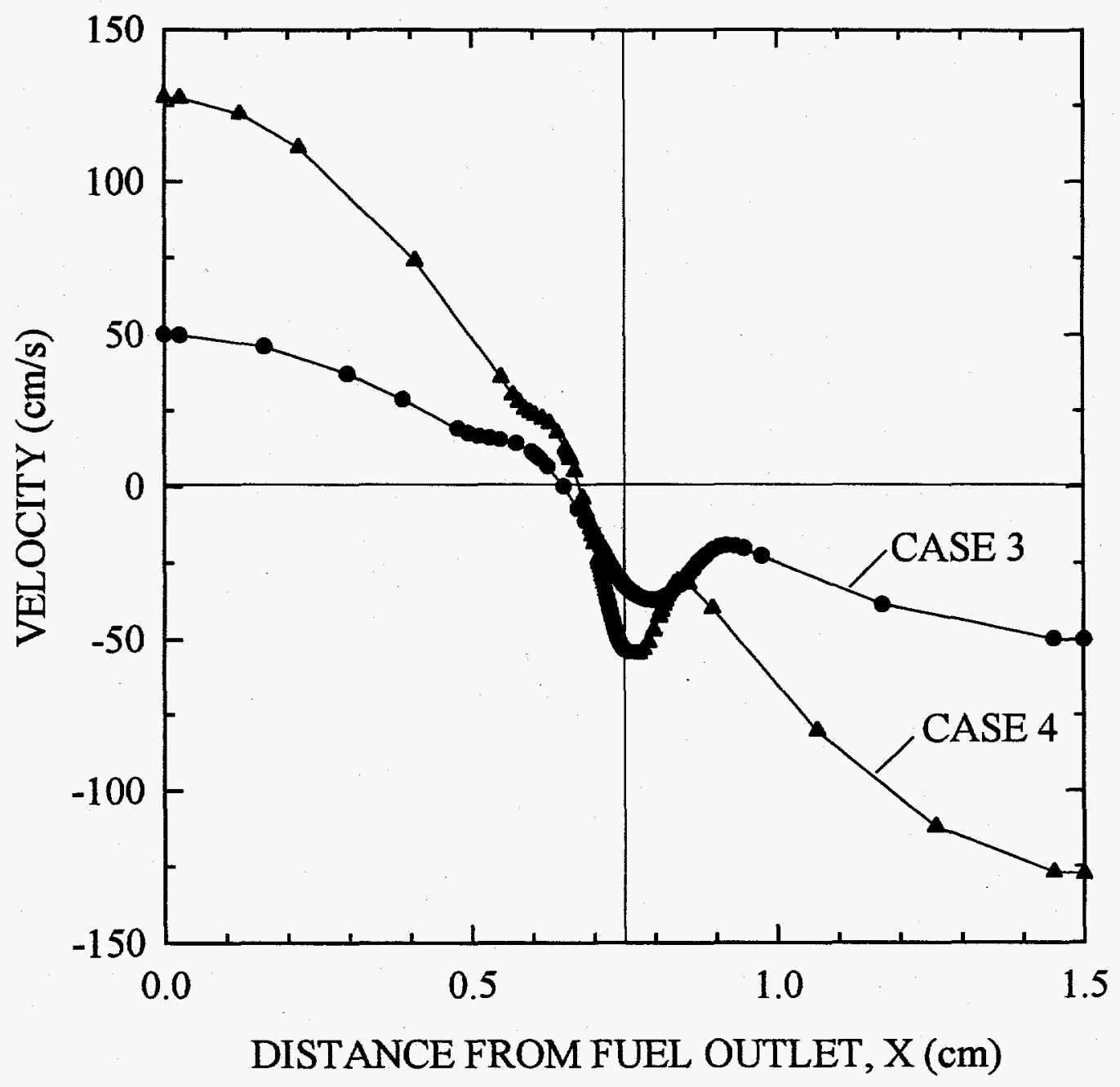

FIGURE 2.23. Comparison of velocity profiles for the two cases where the fuel stream is diluted with $\mathrm{N}_{2}$ for $\mathrm{Z}=0.15$. 
Table 2.3 shows the calculated residence times and the fuel supplied to and consumed by the flames for cases $1-4$. Air dilution (Case 2) causes a decrease in residence time from the nominal no dilution case, while fuel dilution at fixed inlet velocity (Case 3) actually increases the residence time in the high temperature flame zone. The residence time for the fixed fuel mass flux flame (Case 4) is by far the lowest of the four flames considered. These differences in residence times can be understood by studying the flame and stagnation plane positions in the flames of interest. The flame location is defined as the axial position where the temperature reaches a maximum. Table 2.4 shows these locations along with peak flame temperatures and flow velocities at the flame. For the $50 \mathrm{~cm} / \mathrm{s}$ fuel-diluted flame (Case 3), the distance between the flame and the stagnation plane has decreased substantially over that of the no dilution or air dilution flames (Cases 1 and 2). This behavior is very similar to that of the nonreacting flow (cf. Figs. 2.11 and 2.13) in that the stagnation plane has been pushed to the right causing the flame to be located in a lower velocity region. As Eqn. 2.16 indicates, a lower velocity will result in longer residence times. Although the distance between the flame and stagnation plane decreases even more with Case 4 , the residence time still decreases as a result of the much higher velocities in the flame region (cf. Table 2.4 and Fig. 2.23). 
TABLE 2.3. Rate of Fuel Supplied From Nozzle, Residence Time, Fuel Consumption Rate, and Fraction of Fuel Burned $\left(\mathrm{CH}_{4}\right.$-air, $\mathrm{T}=\mathbf{3 0 0}$ K)

\begin{tabular}{|c|c|c|c|c|}
\hline \multirow[b]{2}{*}{ Parameter } & \multirow{2}{*}{\multicolumn{2}{|c|}{$\begin{array}{cc} & u_{0}=50 \mathrm{~cm} / \mathrm{s} \\
\text { No } & \text { Air } \\
\text { Dilution } & \text { Dilution } \\
(Z=0) & (Z=0.15)\end{array}$}} & \multirow{2}{*}{$\begin{array}{c}\text { Fuel } \\
\text { Dihution } \\
(Z=0.15)\end{array}$} & \multirow{2}{*}{$\begin{array}{l}=128 \mathrm{~cm} / \mathrm{s} \\
\text { Fuel } \\
\text { Dilution } \\
(\mathrm{Z}=0.15)\end{array}$} \\
\hline & & & & \\
\hline Case No. & 1 & 2 & 3 & 4 \\
\hline Residence Time for $T>1500 \mathrm{~K}(\mathrm{~ms})$ & 3.2 & 2.6 & 3.6 & 1.2 \\
\hline Total Fuel Supplied $\left(\mathrm{mol} / \mathrm{cm}^{2}-\mathrm{s}\right)$ & $2.03 \times 10^{-3}$ & $2.03 \times 10^{-3}$ & $7.95 \times 10^{-4}$ & $2.03 \times 10^{-3}$ \\
\hline Fuel Consumption $\left(\mathrm{mol} / \mathrm{cm}^{2}-\mathrm{s}\right)$ & $5.87 \times 10^{-5}$ & $5.08 \times 10^{-5}$ & $4.20 \times 10^{-5}$ & $6.34 \times 10^{-5}$ \\
\hline Percentage of Fuel Burned (\%) & 2.89 & 2.50 & 5.28 & 3.12 \\
\hline
\end{tabular}

TABLE 2.4. Location of Stagnation Plane and Flame, Peak Flame Temperature, and Velocity and $\mathrm{N}_{2}$ Mole Fraction at Peak Flame Temperature $\left(\mathrm{CH}_{4}\right.$-air, $\left.\mathrm{T}=300 \mathrm{~K}\right)$

\begin{tabular}{|c|c|c|c|c|}
\hline Parameter & $\begin{array}{c}\text { No } \\
\text { Dilution } \\
(\mathrm{Z}=0)\end{array}$ & $\begin{array}{c}\mathrm{d}_{0}=50 \mathrm{~cm} / \mathrm{s} \\
\text { Air } \\
\text { Dilution } \\
(\mathrm{Z}=0.15)\end{array}$ & $\begin{array}{c}\text { Fuel } \\
\text { Dilution } \\
(\mathrm{Z}=0.15)\end{array}$ & $\begin{array}{l}=128 \mathrm{~cm} / \mathrm{s} \\
\text { Fuel } \\
\text { Dilution } \\
(\mathrm{Z}=0.15)\end{array}$ \\
\hline Case No. & 1 & 2 & 3 & 4 \\
\hline Stagnation Plane Location $(\mathrm{cm})$ & 0.580 & 0.584 & 0.650 & 0.676 \\
\hline Flame Location (cm) & 0.744 & 0.750 & 0.745 & 0.736 \\
\hline \multicolumn{5}{|l|}{ Distance between Flame and } \\
\hline Stagnation Plane (cm) & 0.164 & 0.166 & 0.095 & 0.060 \\
\hline Temperature at Flame (K) & 1927 & 1802 & 1762 & 1672 \\
\hline Velocity at Flame $(\mathrm{cm} / \mathrm{s})$ & -55.5 & -54.4 & -31.0 & -65.6 \\
\hline $\mathrm{N}_{2}$ Mole Fraction at Flame & 0.683 & 0.726 & 0.737 & 0.737 \\
\hline
\end{tabular}


Dilution and flow structure in these air- and fuel-diluted flames are important factors contributing to the differences in NO emission indices to be discussed in the following section. Air and fuel dilution, with the fixed inlet velocity boundary conditions, (Cases 2 and 3) effectively decrease the peak flame temperature by $125 \mathrm{~K}$ and $165 \mathrm{~K}$, respectively, below that of the undiluted flame (Case 1). Fuel dilution with fixed fuel mass flux is by far the most effective and causes a reduction in peak flame temperature of $255 \mathrm{~K}$ below that of the undiluted flame. The small differences in the $\mathrm{N}_{2}$ mole fractions at the flame (cf. Table 2.4) are consistent with the peak flame temperatures observed. The largest $\mathrm{N}_{2}$ mole fraction occurs with the two fuel-dihuted flames and these flames are observed to have the lowest flame temperatures.

\subsubsection{NO Emission Index}

Figure 2.24 shows the NO emission indices for Cases 1 - 4 (cf. Table 2.2). For the fixed inlet velocity flames (Cases 2 and 3), air dilution is more effective than fuel dilution in reducing NO emissions. However, when we fix the fuel mass flux by increasing the inlet velocities to $u_{0}=128 \mathrm{~cm} / \mathrm{s}$ (Case 4), fuel dihution is much more effective than air dilution.

Figure 2.25 shows the NO mole fractions through these diluted flames (Cases 2, 3, and 4). The NO profiles reach a peak near the maximum flame temperatures and are confined to a relatively narrow region. There is some convection-aided diffusion toward 


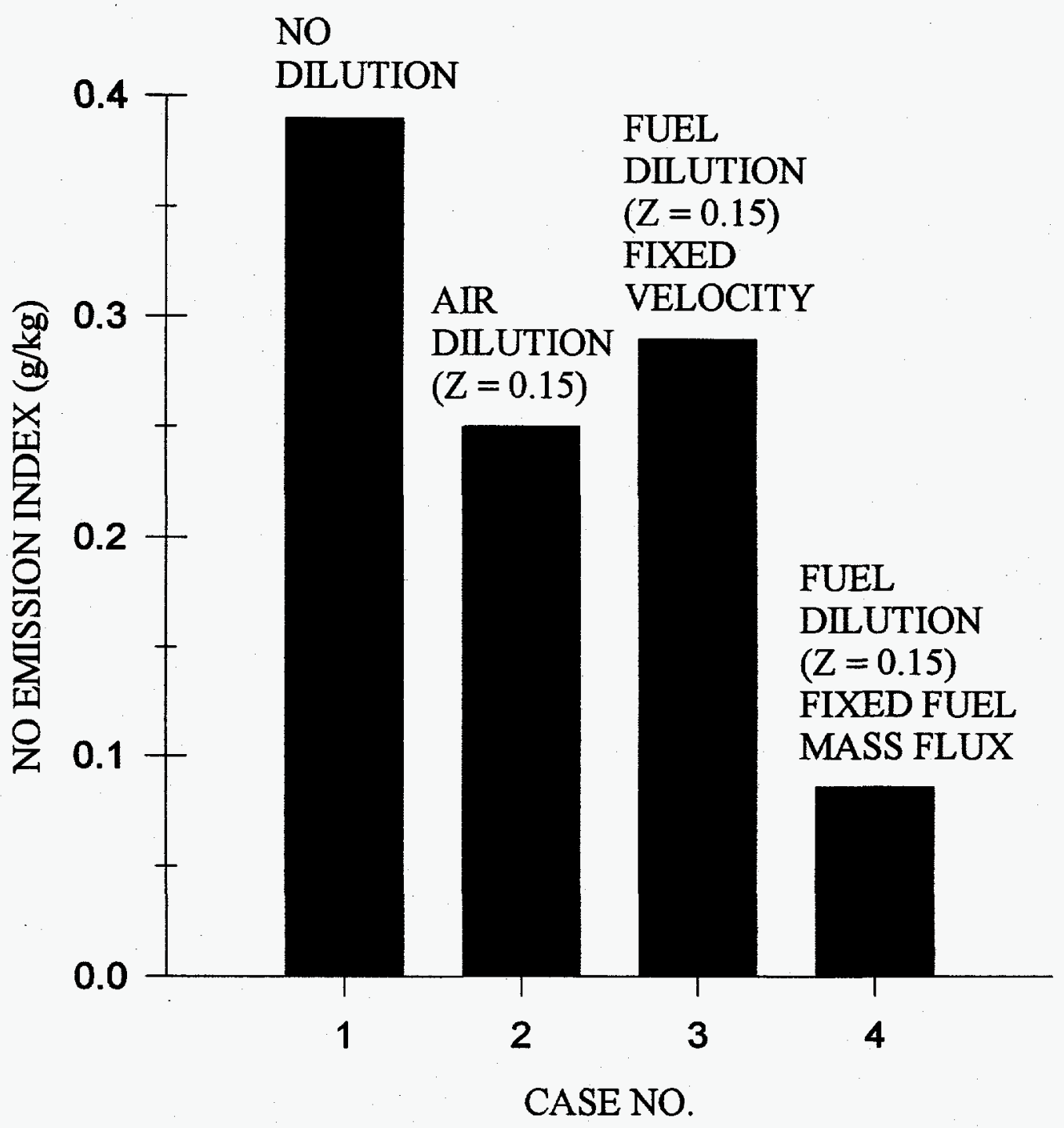

FIGURE 2.24. Nitric oxide emission indices for counterflow diffusion flames for selected conditions (cf. Table 2.2). 


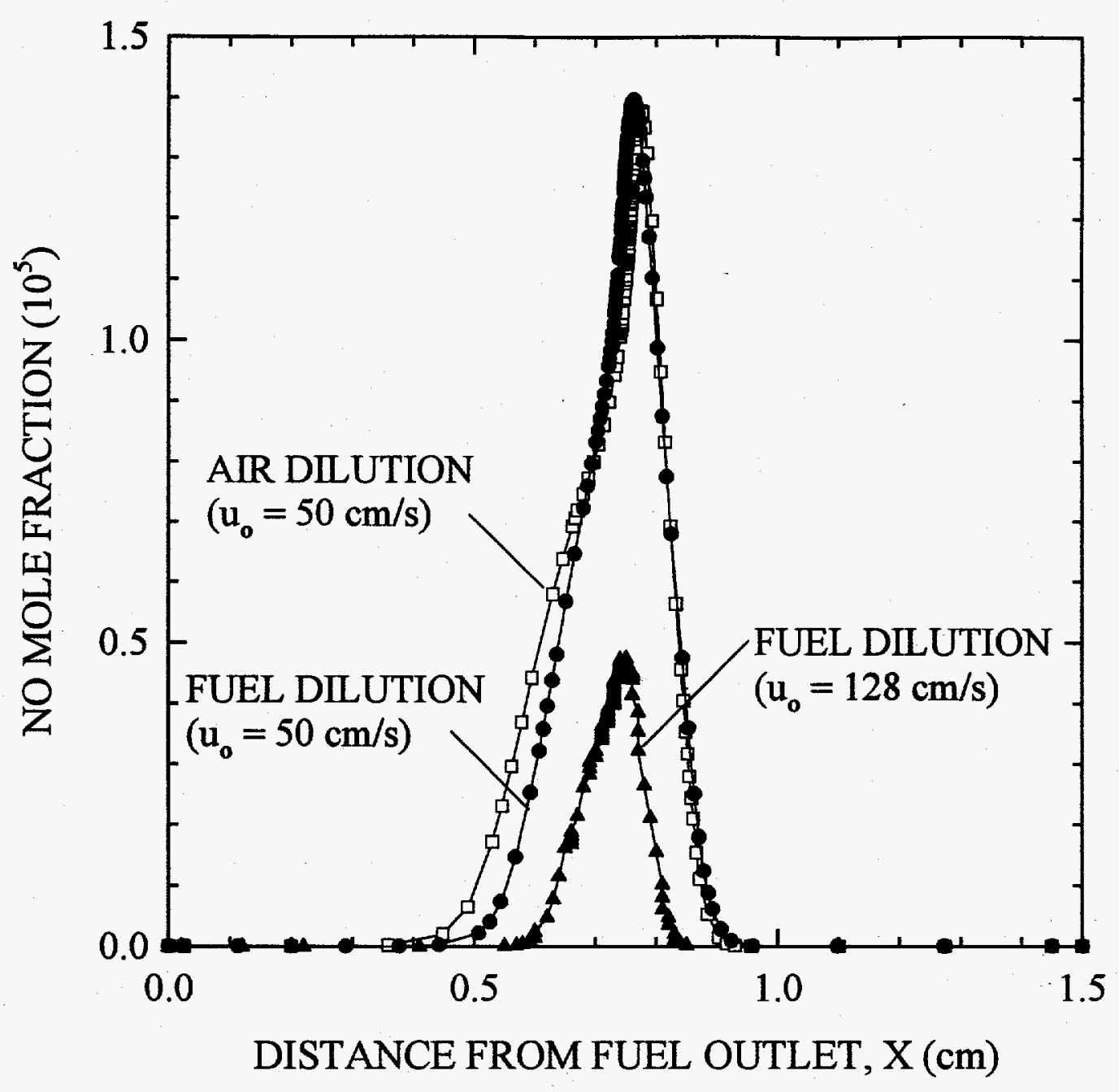

FIGURE 2.25. Nitric oxide mole fraction profiles for the three flame cases with $\mathrm{N}_{2}$ dilution with $Z=0.15$. 
the fuel nozzle exit $(x=0 \mathrm{~cm})$. In comparison to the $\mathrm{H}_{2}$-air flames (cf. Fig 2.6), the NO profiles are much narrower in these $\mathrm{CH}_{4}$-air flames.

Figures 2.26 and 2.27 show the NO and $\mathrm{CH}_{4}$ volumetric production rates respectively for these same cases of interest. The axial coordinate has been enlarged to show the detailed profiles. The NO production profiles are characterized by a relatively large destruction zone on the fuel side of the flame, followed by a large production peak near the flame location. The destruction region of the NO production profile is the recycling of NO via the HCN route described by Miller and Bowman [2]. The small peaks to the right of the main production peak are associated with the interconversion of NO to $\mathrm{NO}_{2}$. In Fig. 2.27 we see a large increase in the fuel consumption rate associated with the fixed inlet mass flux condition, Case 4, due to larger concentration and velocity gradients as compared to the fixed inlet velocity simulations, Cases 2 and 3.

Table 2.5 summarizes the net production rates of $\mathrm{CH}_{4}$ and NO for Cases 1-4. The net NO formation is further broken down into the production and destruction components for each flame condition. These two components are the positive and negative regions under the volumetric NO production rate-versus-distance curves (cf. Fig. 2.26). 


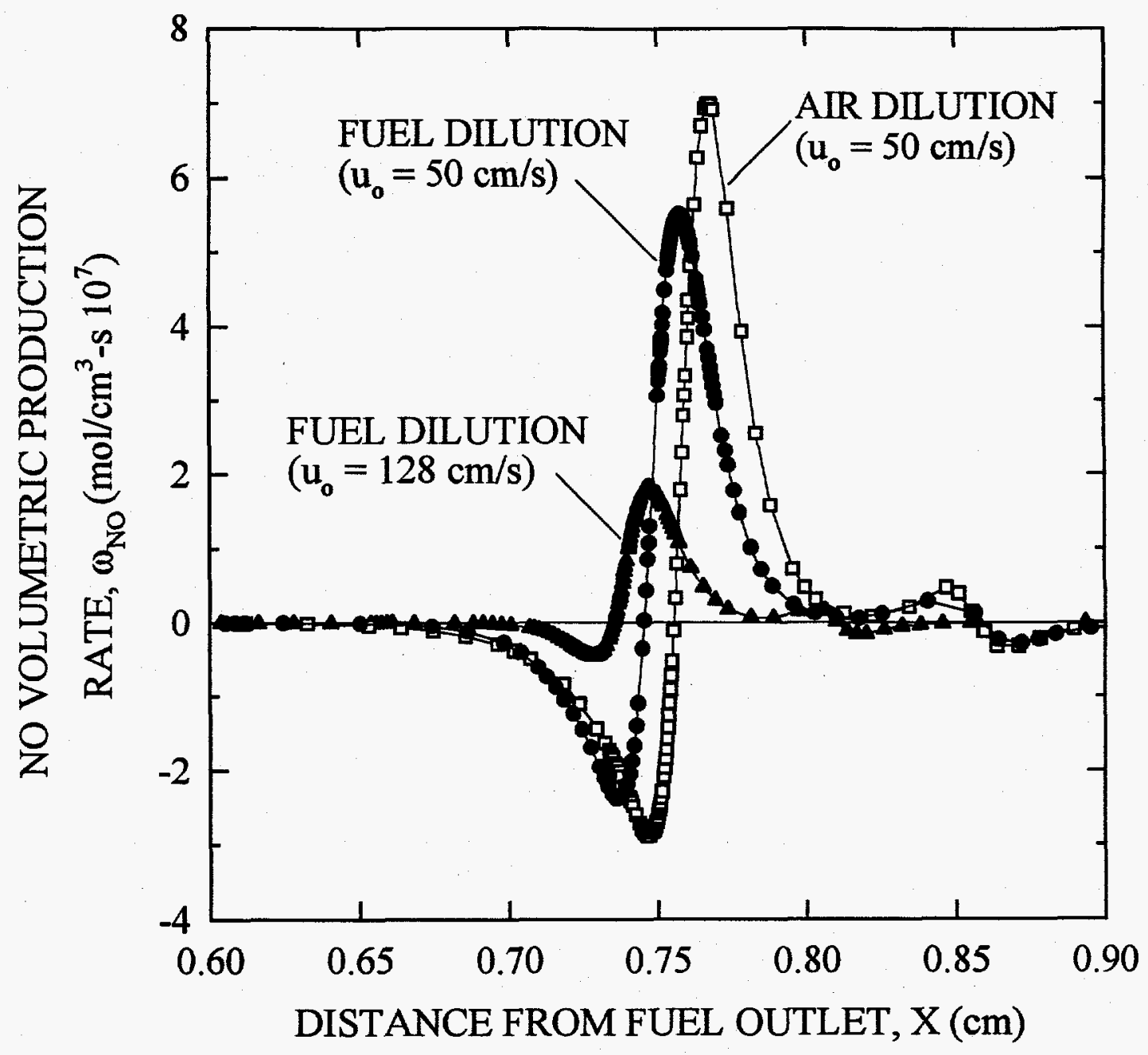

FIGURE 2.26. Nitric oxide volumetric production rates for the three flame cases with $\mathrm{N}_{2}$ dilution with $\mathrm{Z}=\mathbf{0 . 1 5}$. 


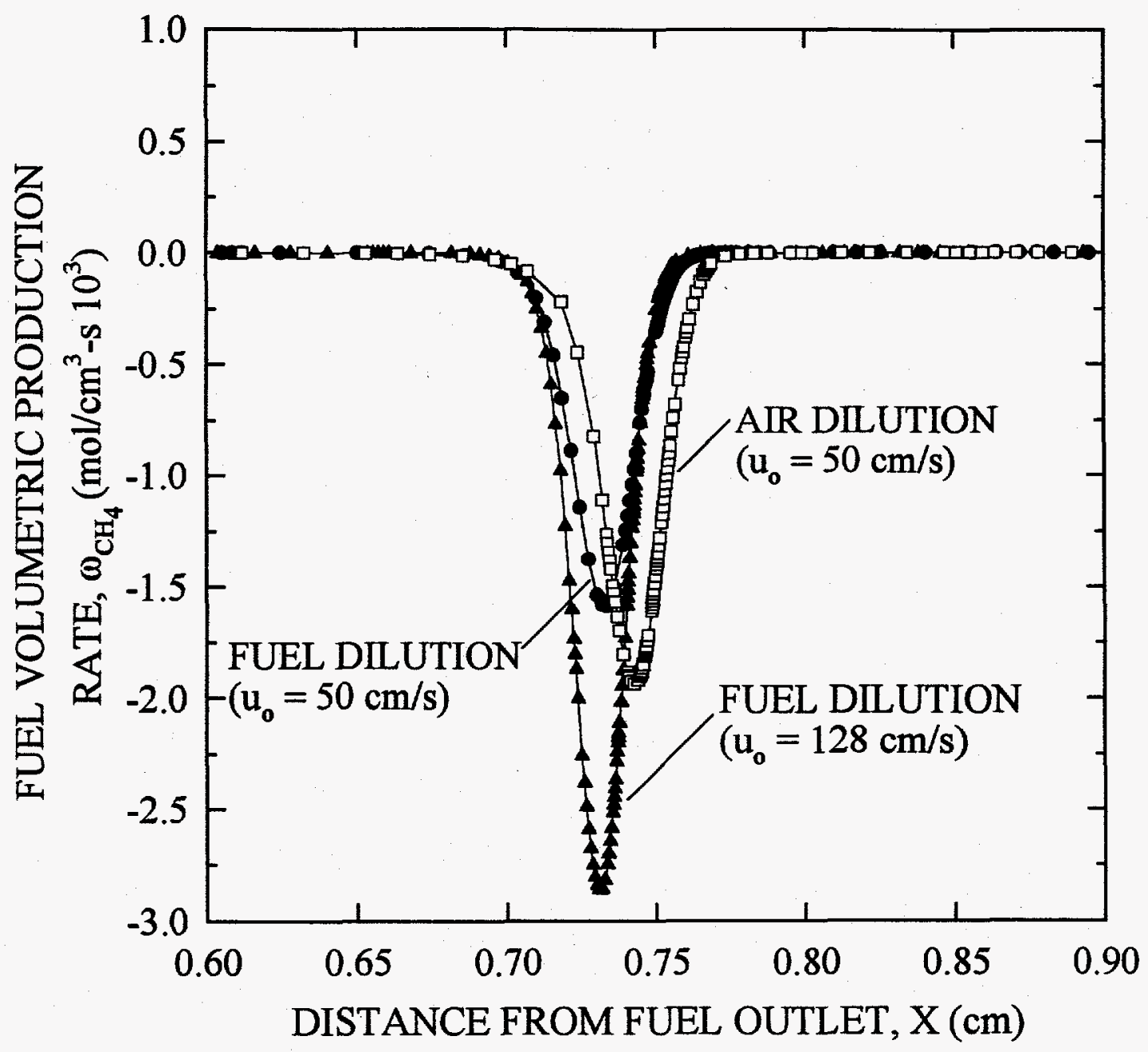

FIGURE 2.27. Fuel $\left(\mathrm{CH}_{4}\right)$ volumetric production rates for the three flame cases with $\mathrm{N}_{2}$ dilution with $Z=0.15$. 
TABLE 2.5. Contributions of Various Factors to NO Emission Index $\left(\mathrm{CH}_{4}\right.$-air, $\mathrm{T}=300 \mathrm{~K}$ )

\begin{tabular}{|c|c|c|c|c|}
\hline Parameter & $\begin{array}{c}\text { No } \\
\text { Dilution } \\
(Z=0)\end{array}$ & $\begin{array}{c}=50 \mathrm{~cm} / \mathrm{s} \\
\text { Air } \\
\text { Dilution } \\
(Z=0.15)\end{array}$ & $\begin{array}{c}\text { Fuel } \\
\text { Dilution } \\
(Z=0.15)\end{array}$ & $\begin{array}{l}=128 \mathrm{~cm} / \mathrm{s} \\
\text { Fuel } \\
\text { Dilution } \\
(Z=0.15)\end{array}$ \\
\hline Case No. & 1 & 2 & 3 & 4 \\
\hline Fuel Consumption $\left(\mathrm{mol} / \mathrm{cm}^{2}-\mathrm{s}\right)$ & $5.87 \times 10^{-5}$ & $5.00 \times 10^{-5}$ & $4.20 \times 10^{-5}$ & $6.34 \times 10^{-5}$ \\
\hline NO Production (mol $\left./ \mathrm{cm}^{2}-\mathrm{s}\right)$ & $35.9 \times 10^{-9}$ & $16.4 \times 10^{-9}$ & $13.6 \times 10^{-9}$ & $4.10 \times 10^{-9}$ \\
\hline NO Destruction $\left(\mathrm{mol} / \mathrm{cm}^{2}-\mathrm{s}\right)$ & $23.6 \times 10^{-9}$ & $9.55 \times 10^{-9}$ & $7.08 \times 10^{-9}$ & $1.17 \times 10^{-9}$ \\
\hline Net NO Formation $\left(\mathrm{mol} / \mathrm{cm}^{2}-\mathrm{s}\right)$ & $12.3 \times 10^{-9}$ & $6.85 \times 10^{-9}$ & $6.52 \times 10^{-9}$ & $2.93 \times 10^{-9}$ \\
\hline Ratio of Production to Destruction & 1.52 & 1.72 & 1.92 & 3.50 \\
\hline NO Emission Index $(\mathrm{g} / \mathrm{kg})$ & 0.39 & 0.25 & 0.29 & 0.086 \\
\hline
\end{tabular}

Table 2.5 provides some valuable insight into the NO emission indices observed for Cases 1-4. Comparing Cases 2 and 3, we see that the net NO formation is nearly identical for these two flames. However, the fuel consumption rate of the fuel-diluted (Case 3) flame is significantly less than the air-diluted (Case 2) flame. Since the emission index calculation is the ratio of the NO produced to the fuel consumed (cf. Eqn. 2.14), the larger index obtained with fuel dilution is a result of the decreased fuel consumption rate. For the fixed fuel mass flux flame, Case 4, we see that the fuel consumption rate increases and the net NO formation rate decreases significantly over that of the other diluted flames (Cases 2 and 3). The increased fuel consumption rate is a result of the steeper concentration and velocity gradients associated with the higher inlet velocity of this fixed fuel mass flux flame. Both the increased fuel consumption and decreased NO production 
contribute to the much lower NO emission index observed in this fixed fuel mass flux flame. Specifically, the emission index for this flame $\left(\mathrm{EI}_{\mathrm{No}}=0.086 \mathrm{~g} / \mathrm{kg}\right)$ is 3.4 times lower than fixed-velocity fuel-diluted flame and 2.9 times lower than the corresponding air-diluted flame. Even though Case 4 yields the lowest NO emission index, the ratio of NO production to destruction is by far the largest, i.e., 3.50 versus 1.92 and 1.72 , in this flame (cf. Fig. 2.26). This suggests that the relative importance of the various NOformation pathways, especially the destruction of NO through the $\mathrm{HCN}$ recycle route in the Fenimore mechanism, changes significantly between the $128 \mathrm{~cm} / \mathrm{s}$ and the $50 \mathrm{~cm} / \mathrm{s}$ conditions. Further insight is provided by the following parametric study.

\subsubsection{Parametric Studies}

A number of parametric studies were conducted in which a range of diluent fractions, $Z$, were investigated in the $\mathrm{CH}_{4}$-air flames. In addition, the effect of preheating the reactants was studied using reactant inlet temperatures of $300 \mathrm{~K}$ and $500 \mathrm{~K}$. The $300 \mathrm{~K}$ results presented previously are a subset of these parametric studies. The inlet velocity boundary conditions were similar to those employed previously $\left(\mathrm{u}_{0}=50 \mathrm{~cm} / \mathrm{s}\right)$ and the fixed fuel mass flux condition $\left(0.326 \mathrm{~kg} / \mathrm{m}^{2}\right.$-s at $300 \mathrm{~K}$ and $0.189 \mathrm{~kg} / \mathrm{m}^{2}$-s at $\left.500 \mathrm{~K}\right)$.

Figure 2.28 shows the NO emission indices versus the $N_{2}$ diluent fraction, $Z$, for the range of tests conducted. Here we see that air dilution is more effective than fuel dilution for the fixed inlet velocity flames $\left(u_{0}=50 \mathrm{~cm} / \mathrm{s}\right)$ at both inlet conditions of $300 \mathrm{~K}$ 


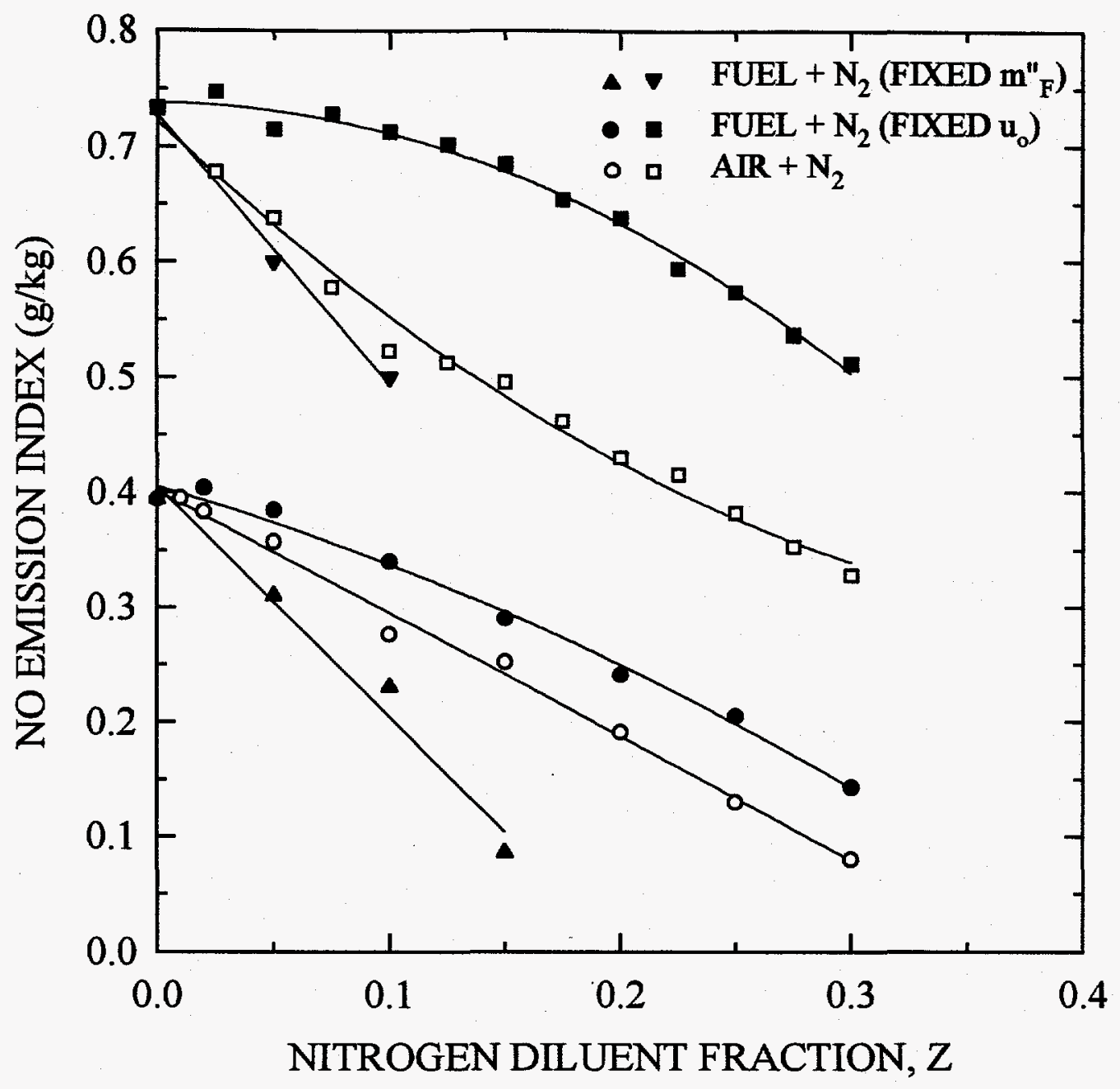

FIGURE 2.28. Calculated NO emission indices for counterflow $\mathrm{CH}_{4}$-air flames for $\mathrm{N}_{2}$ addition to either the air or fuel streams with reactants at $500 \mathrm{~K}$ (upper curves) and $300 \mathrm{~K}$ (lower curves). Fuel dilution is accomplished either with fixed nozzle exit velocities or fixed fuel mass flux. 
and $500 \mathrm{~K}$. The effectiveness of the air-diluted flames in decreasing $\mathrm{NO}_{\mathrm{x}}$ emissions relative to that of the fixed-velocity fuel-diluted flames is more pronounced with preheated reactants. At both inlet temperature conditions $(300 \mathrm{~K}$ and $500 \mathrm{~K})$, the fixed fuel mass flux flames resulted in the lowest NO emission indices. Figure 2.29 shows the residence times associated with these flames. Here we see the strong correlation between residence time and the resulting NO emission index (cf. Fig. 2.28). The fixed fuel mass flux flames, which produce the lowest NO emission indices, have the shortest high-temperature residence times. Fixed fuel mass flux is the condition that is most applicable to practice; however, caution must be exercised in extrapolating the laminar flame results to real boilers both because the geometries are different and, most importantly, the practical flow is governed by turbulent mixing. Nevertheless, we gain valuable insight that local residence times for NO formation in a flame are affected by how the diluent is added to the system.

Figures 2.30 and 2.31 show the maximum flame temperatures and $\mathrm{N}_{2}$ diluent mole fractions at the maximum flame temperatures for the $300 \mathrm{~K}$ and $500 \mathrm{~K}$ flames, respectively. Here we see that $\mathrm{N}_{2}$ mole fractions for the fixed inlet velocity fuel-diluted flames are significantly higher than the corresponding air-diluted flames, and the corresponding maximum flame temperatures are slightly lower with fuel dihution. In addition, the $\mathrm{N}_{2}$ mole fractions are approximately the same for the fixed fuel mass flux flames as the fixed inlet velocity fuel-diluted flames; however, the peak flame temperatures are suppressed even further. This greater temperature depression is thought to be an additional consequence of the shorter residence times in these flames. These shorter 


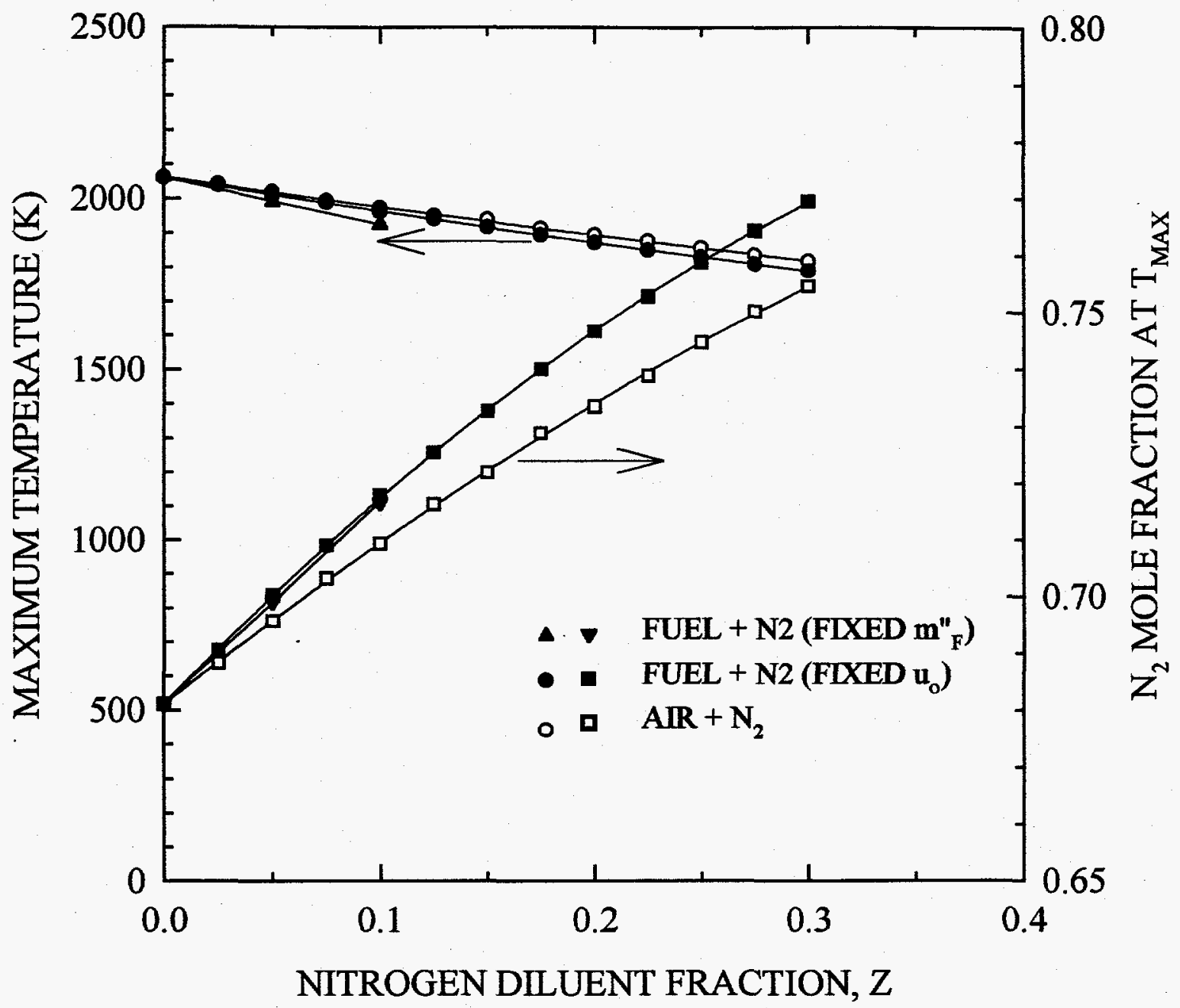

FIGURE 2.31. Calculated maximum temperature and $\mathrm{N}_{2}$ mole fraction at the location of maximum temperature as functions of $\mathrm{N}_{2}$ addition. Reactants enter at 500 $\mathbf{K}$ 
residence times can cause a greater departure from chemical equilibrium. It is well known that high strain rates can cause superequilibrium concentrations of flame radicals, which, in turn, cause temperatures to be below equilibrium levels [25]. 


\section{Chapter 3}

\section{EXPERIMENTAL METHOD}

\subsection{Coannular Laminar Diffusion Flame Burner}

Some quantitative differences between fuel dilution and air dilution were studied using a laminar jet flame. Although the geometry differs from that of the numerical simulations, a number of similarities exist. For example, at low velocity conditions for the counterflow, the structure of both flames are dominated by diffusional processes and, hence, comparable. In addition, the axisymmetric geometry and steady nature of these jet flames simplify experimental efforts and subsequent data analysis. For example, since all of the fuel supplied is consumed in the jet flame, the $\mathrm{NO}_{\mathrm{x}}$ emission index can be calculated in a straightforward manner. This would not be possible in a counterflow geometry since much of the fuel escapes unburned (cf. Table 2.3).

\subsubsection{Coannular Burner}

The coannular burner is shown in Fig. 3.1 and is similar to a bumer used extensively by Santoro and coworkers in soot studies $[26,27]$. Fuel flows through the central tube which has an inside diameter of $10.92 \mathrm{~mm}$ and an outside diameter of 12.7 $\mathrm{mm}$. The overall fuel tube length is $106 \mathrm{~mm}$ and the tube extends $4.8 \mathrm{~mm}$ above the 


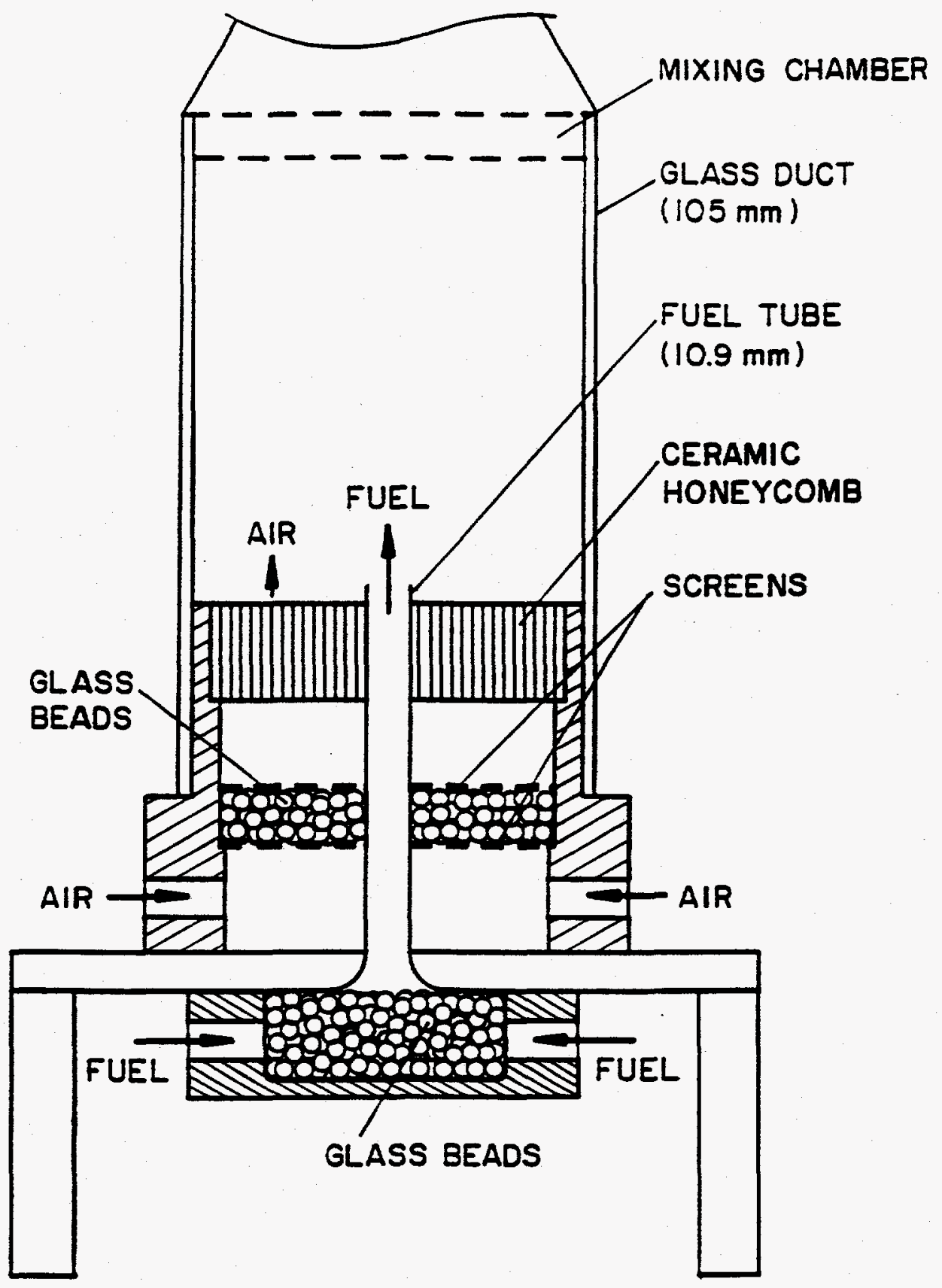

FIGURE 3.1. Laminar jet flame bumer. 
ceramic honeycomb. A low-velocity coflow of air surrounds the fuel tube producing stable, overventilated, conical flames. A $12.7 \mathrm{~mm}$ thick bed of $3.4 \mathrm{~mm}$ diameter glass beads distributes the air flow uniformly over the annular space, while a $25.4 \mathrm{~mm}$ thick honeycomb with a $1.5 \mathrm{~mm}$ cell size provides a laminar flow.

The flame was surrounded by a either a glass or aluminum duct (105 mm i.d. and $230 \mathrm{~mm}$ long) during operation. The duct prevented any room drafts from influencing the flame. For exhaust-gas sampling measurements, a glass duct was used which allowed the flames to be easily photographed. A series of baffle plates were located above the duct to thoroughly mix the exhaust gases. The mixed product gases were then passed through a chimney from which samples were withdrawn. For in-flame temperature measurements, an aluminum duct with two vertical slots machined at 180 degrees was used to provide access for thermocouple insertion.

\subsubsection{Flow Metering and Heating System}

Figure 3.2 shows the air, fuel, and $\mathrm{N}_{2}$ diluent flow controls and heating systems. The air flow was provided by an in-house air compressor. Filters were placed in-line to remove both particulates and moisture. The fuel used in the experiments was technical grade $\mathrm{CH}_{4}\left(99.6 \%\right.$ purity). Similar to the numerical simulations, $\mathrm{N}_{2}$ was used as the simulated flue gases. The flow rates of the various streams are monitored, prior to any preheating, with calibrated rotameters. The fuel stream and any diluent is heated, when desired, by variable-voltage controlled heating tapes. The air stream and any diluent is 


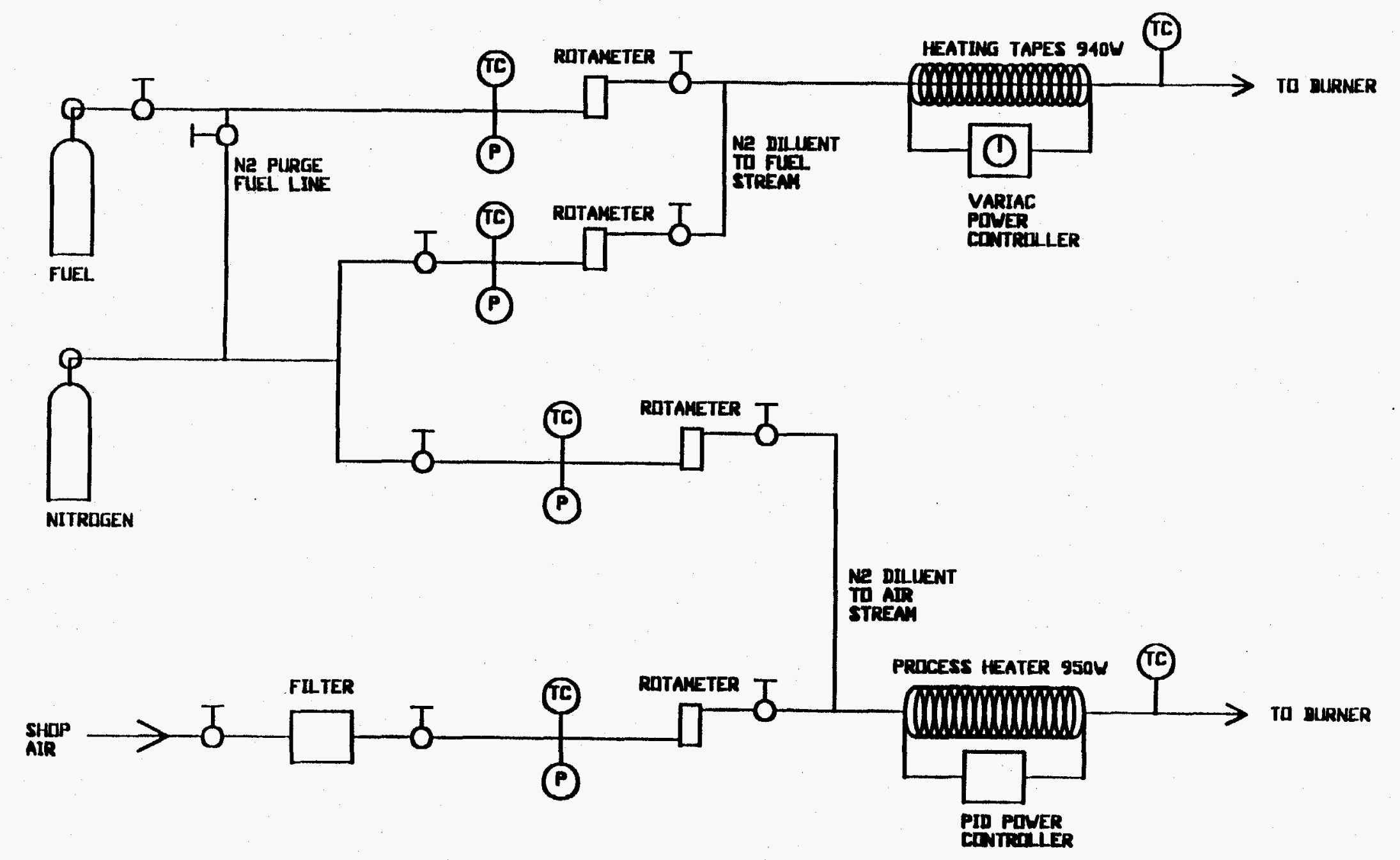

FIGURE 3.2. Air, fuel, and $\mathrm{N}_{2}$ diluent flow control, metering, and heating schematic. 
heated by a $950 \mathrm{~W}$ process heater with a PID controller. The burner base assembly is well insulated to minimize heat loss to the surroundings. The maximum attainable gas temperature with this arrangement is approximately $140^{\circ} \mathrm{C}(413 \mathrm{~K})$.

The product gas sampling and analysis systems are shown in Fig. 3.3. Samples are withdrawn from the chimney through a stainless steel, water-cooled sampling probe. Cooling water temperatures are maintained above the dew point of the product gases to avoid water condensation within the probe. Teflon tubing is used from the probe to the analyzers to minimize any $\mathrm{NO}$ or $\mathrm{NO}_{2}$ adsorption within the sampling lines. Moisture is removed from the line by an ice-bath water trap before the sampled gases enter the analyzers.

\subsubsection{Data Acquisition}

A chemiluminescent analyzer (TECO Model 10-A with factory-installed cooled PMT) is used to measure NO and $\mathrm{NO}_{\mathrm{x}}$ concentrations. The analyzer is equipped with a stainless-steel $\mathrm{NO}_{2}$-to-NO converter with a measured efficiency exceeding $97 \%$. A strip chart recorder is used in conjunction with the $\mathrm{NO}_{\mathrm{x}}$ analyzer to determine when a steadystate output is achieved. Carbon dioxide concentration measurements are made using either a long- or a short-path nondispersive infrared analyzer (Horiba PIR-2000). The long-path $\mathrm{CO}_{2}$ analyzer permits accurate measurements to a parts-per-million level. A gas-filter correlation analyzer (TECO Model 48) is used to measure CO concentrations. The analyzers are carefully calibrated with appropriate span and zero gases before each 


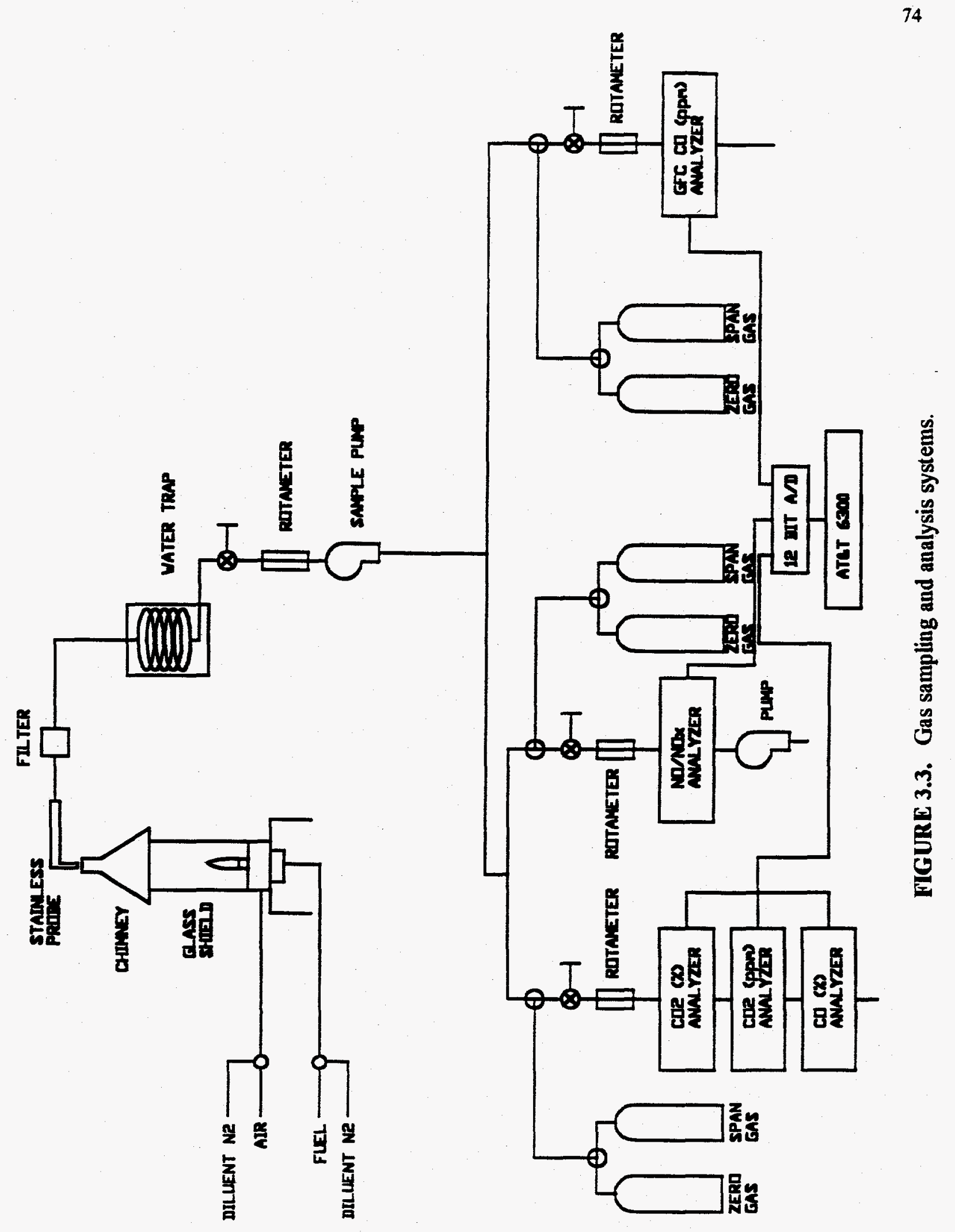


experiment. An AT\&T 6300 micro-computer is used to record the data from the analyzers.

Temperature measurements were made using a fine-wire $\mathrm{Pt}-\mathrm{Pt} / 10 \% \mathrm{Rh}$ thermocouple. The complete thermocouple assembly is shown in Fig. 3.4. A larger 254 $\mu \mathrm{m}$ diameter wire was used from the connector to the fine wire to provide rigid support to the more fragile $127 \mu \mathrm{m}$ diameter wire used to form the thermocouple bead. The bead and the connection between the large and small diameter wire were made using a microtorch. The resultant bead diameter was approximately $160 \mu \mathrm{m}$. The thermocouple bead was then coated with a high-temperature adhesive consisting of $\mathrm{Al}_{2} \mathrm{O}_{3}$ in a silicate base (Aremco, Ceremabond 569) to prevent catalytic reactions on the bead surface. After coating, the final bead diameter, measured using a calibrated microscope, was $238 \mu \mathrm{m}$.

A correction was applied to the temperature measurements to account for radiative heat losses from the bead surface. The detailed calculations are given in Appendix B. The maximum temperature corrections are approximately $200 \mathrm{~K}$ in the high-temperature flame region. In cooler regions, the temperature corrections were significantly lower. All of the temperature measurements presented in this work are the corrected values.

A three-dimensional manual traversing system was used to provide accurate positioning of the thermocouple bead in the flame. The burner was mounted on a onedimensional traverse which was connected to a digital measuring device (Metronics, QC1000). Stage positioning could be made in increments of $0.005 \mathrm{~mm}$ with an accuracy of $0.13 \mathrm{~mm} / \mathrm{m}$. Radial temperature profiles were acquired by translating the burner while the probe was rigidly mounted to the other two traverses. The second horizontal traverse was 


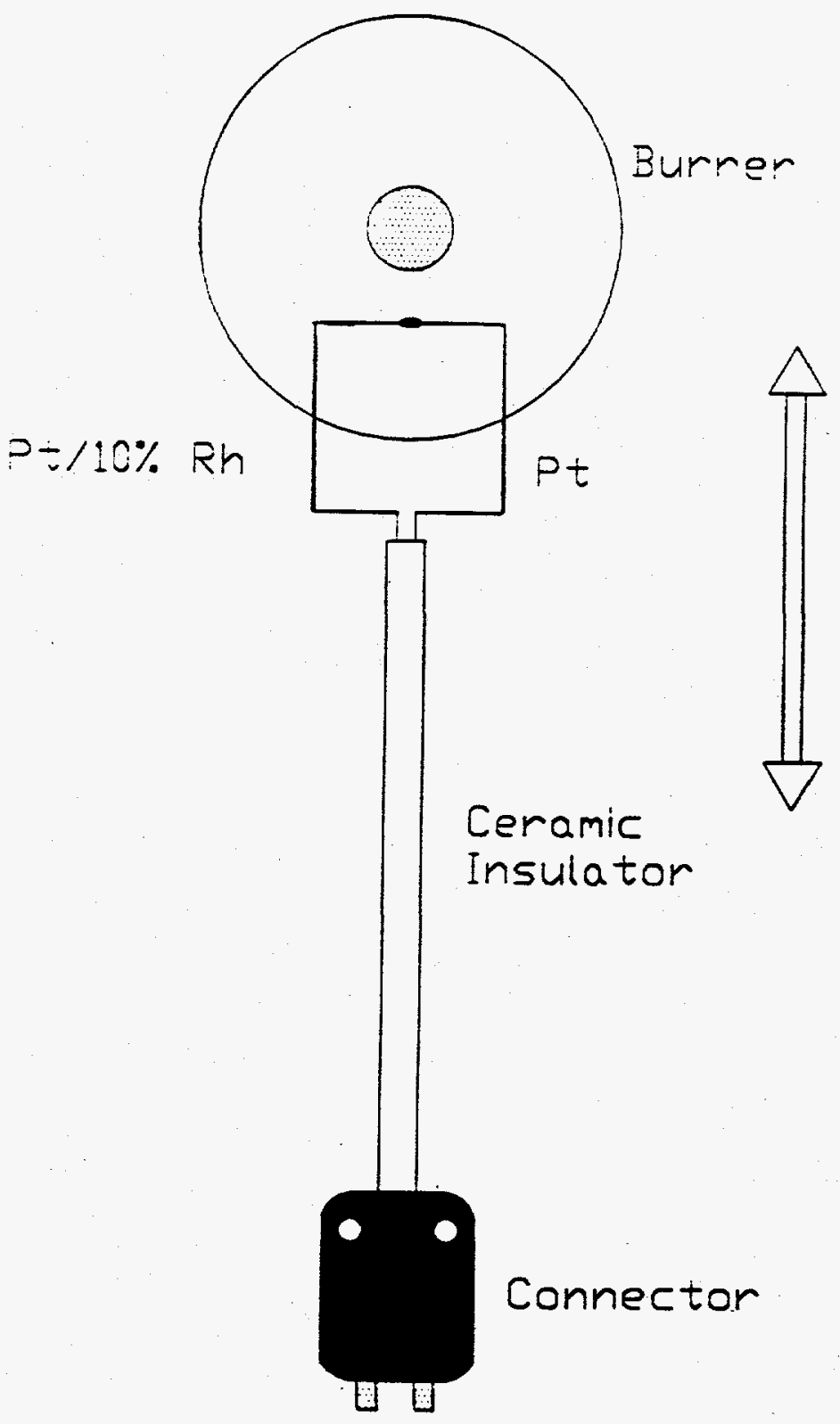

FIGURE 3.4. Schematic of fine wire thermocouple showing the direction of motion used for acquiring radial temperature profiles. 
used to position the bead at the flame centerline, while the vertical traverse was used for accurate axial positioning of the thermocouple in the flame. These last two traverses had positioning capability of $0.01 \mathrm{~mm}$ with an accuracy of $0.13 \mathrm{~mm} / \mathrm{m}$

In the flame regions, where soot was appreciable, the thermocouple was rapidly inserted to the measurement location and the steady state temperature was recorded prior to any soot build-up on the thermocouple surface. Between each measurement, the thermocouple was placed in a high-temperature oxidation region of the flame to remove any soot that had deposited on the thermocouple surface [28].

\subsubsection{Emission Indices}

$\mathrm{NO}_{\mathrm{x}}$ and $\mathrm{CO}$ emission indices were derived based on overall mass and species conservation principles (cf. Appendix C). The emission indices were calculated from the measured mole fractions of $\mathrm{NO}, \mathrm{NO}_{\mathrm{x}}, \mathrm{CO}$, and $\mathrm{CO}_{2}$ in the product gas stream according to:

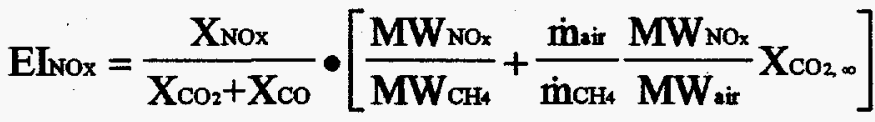

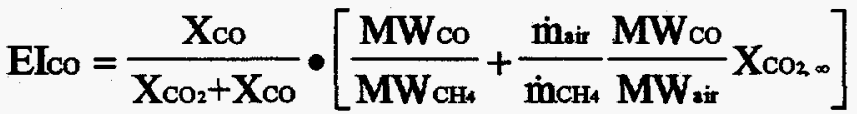

where $\mathrm{X}_{\mathrm{CO}_{2 \infty} \infty}$ is the $\mathrm{CO}_{2}$ mole fraction in the air stream. The $\mathrm{NO}_{\mathrm{X}}$ emission indices are calculated with the assumption that all of the $\mathrm{NO}_{\mathrm{X}}$ eventually oxidizes to form $\mathrm{NO}_{2}$; thus, the $\mathrm{NO}_{\mathrm{x}}$ molecular weight used in Eqn. 3.1 is that of $\mathrm{NO}_{2}$. For the $\mathrm{CH}_{4}$ flames in this work, both $\mathrm{X}_{\mathrm{CO}}$ and the second term in the brackets of Eqns. 3.1 and 3.2 are negligible; 
therefore, the emission indices are readily calculated without a knowledge of the air and fuel stream mass flow rates, i.e.,

$$
\begin{aligned}
& \mathrm{EI}_{\mathrm{NOx}}=\frac{\mathbf{X}_{\mathrm{NOx}}}{\mathbf{X}_{\mathrm{CO}_{2}}}\left[\frac{\mathbf{M W}_{\mathrm{NO}_{2}}}{\mathbf{M W}_{\mathrm{CH}_{4}}}\right] \\
& E_{\mathrm{co}}=\frac{\mathbf{X}_{\mathrm{CO}}}{\mathrm{X}_{\mathrm{CO}_{2}}}\left[\frac{\mathbf{M W}_{\mathrm{co}}}{\mathbf{M W}_{\mathrm{CH}_{4}}}\right]
\end{aligned}
$$

\subsubsection{Experimental Test Conditions}

Preliminary tests were conducted, without fuel or air stream dilution, to determine the range of fuel and air flow velocities that produced a stable flame. The system was checked to insure that the air-to-fuel ratio based on known air and fuel mass flow rates matched that of the exhaust-gas composition measurements. Several leaks in the exhaustgas sampling lines were fixed and consistent agreement was obtained. The baseline, no dilution, flame condition was chosen, based on desirable exit velocities, within the stable operating range of the burner. These baseline conditions are shown in Table 3.1 for room temperature reactants $(293 \mathrm{~K})$ and for preheated reactants (nominally $400 \mathrm{~K}$ ). From these baseline conditions, $\mathrm{N}_{2}$ was added to either the air stream, simulating FGR, or the fuel stream, simulating FIR. Whether the diluent was added to the air or fuel stream, the mass flow rates of the air and fuel streams were held constant, similar to the fixed fuel mass flux numerical studies. 
TABLE 3.1 Baseline Experimental Flame Conditions (No dihtion)

\begin{tabular}{lcc}
\hline Flame Designation & A & B \\
\hline Fuel Temperature (K) & 293 & 413 \\
Air Temperature (K) & 293 & 398 \\
Fuel Flowrate $(\mathrm{mg} / \mathrm{s})$ & 3.0 & 3.3 \\
Air Flowrate $(\mathrm{mg} / \mathrm{s})$ & 243 & 243 \\
Mean Fuel Velocity (cm/s) & 5.0 & 7.8 \\
Mean Air Velocity $(\mathrm{cm} / \mathrm{s})$ & 2.4 & 3.5 \\
\hline
\end{tabular}

The definition of the dilution parameter, $Z$, is identical to that used in the numerical flame calculations (cf. Eqn. 2.16). For $\mathrm{CH}_{4}$-air flames, the stoichiometric mixture fraction,

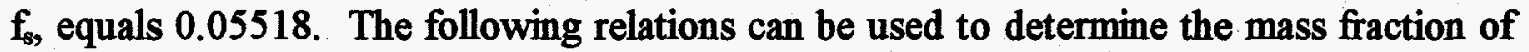
diluent $\mathrm{N}_{2}$ in the fuel or air stream respectively for a given diluent fraction, $\mathrm{Z}$ :

$$
\begin{aligned}
& Y_{N_{2} \text { fuel }}=\frac{Z}{f_{s}+Z}, \\
& Y_{N_{2} \text { air }}=\frac{Z}{1-f_{s}+Z} .
\end{aligned}
$$

The maximum diluent fraction used in the first set of experiments described is $Z=0.2$, which corresponds to $Y_{\mathrm{N}_{2} \text { fuel }}=0.78$ and $Y_{\mathrm{N}_{2} \text {, sir }}=0.175$. Under certain conditions, a value of the dilution parameter of $Z=0.3$ was used, this will be described in more detail in the sections that follow. 


\subsection{CH$_{4}$-Air Experimental Flame Results}

Figure 3.5 shows the $\mathrm{NO}_{\mathrm{x}}$ emission index versus diluent fraction, $\mathrm{Z}$, for the airand fuel-diluted flames for both room temperature and preheated reactant conditions. For both reactant temperature conditions, air dilution is more effective than fuel dilution in reducing the $\mathrm{NO}_{\mathrm{x}}$ emission index; however, the results are more pronounced with the preheated flames. Even though the differences between air and fuel dilution were small at room temperature, the trends are thought to be real due to the rather small uncertainty in the data obtained. For example, the high-temperature, $Z=0.10$, fuel dilution test condition was repeated multiple times resulting in a $95 \%$ confidence interval $\mathrm{NO}_{\mathrm{x}}$ emission index of $3.34 \pm 0.03 \mathrm{~g} / \mathrm{kg}$ based on student $\mathrm{t}$-statistics for five samples. In addition, the preheated data set was tested for repeatability several weeks after the first data set was obtained, hence, the dual symbols on the upper curves. As is indicated in Fig. 3.5, data replication is quite good.

These $\mathrm{NO}_{\mathrm{x}}$ emission index trends are similar to those of the $\mathrm{CH}_{4}$-air fixed inlet velocity numerical simulations (cf. Figs 2.14 and 2.15 ), but contrary to the fixed fuel mass flux simulations (cf. Fig 2.28), as well as the turbulent combustion boiler experiments conducted by Hopkins [1] and Reese [24]. Since the fuel mass flux is fixed in these experimental flames, we might expect similar results to the numerical fixed fuel mass flux simulations discussed previously. However, the increase in jet exit velocities associated with diluting the fuel stream are minor compared to the large buoyancy-induced velocities

established in these flames. Velocity measurements in similar flames by Santoro and 


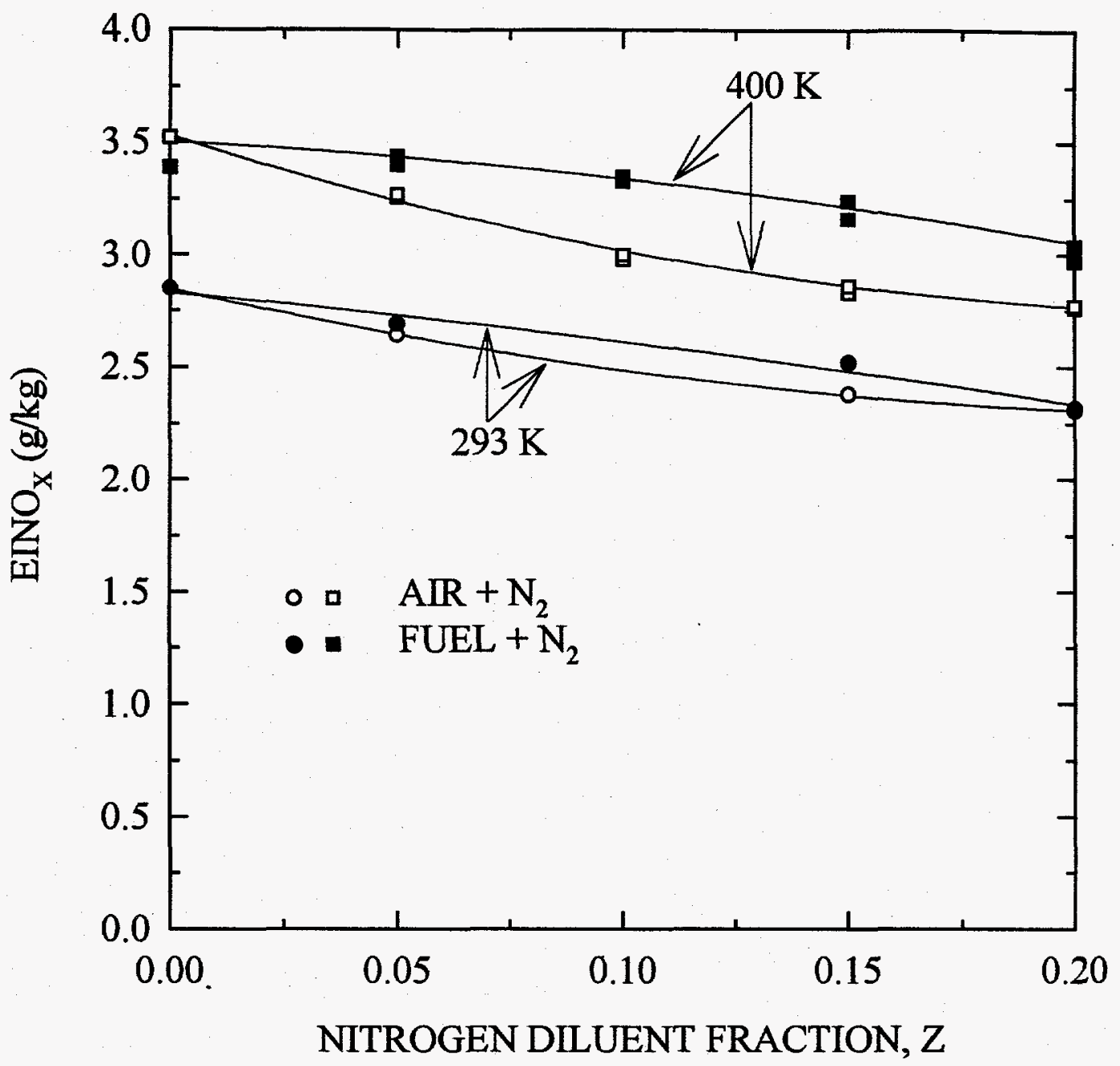

FIGURE 3.5 $\mathrm{NO}_{\mathrm{x}}$ emission indices for laminar $\mathrm{CH}_{4}$ jet flames with various levels of $\mathrm{N}_{2}$ dilution in either the fuel or air stream. The fuel flowrate is held constant as the diluent is added. 
coworkers [26] show that the jet rapidly accelerates as the buoyant force increases as more and more hot products are formed. Near the flame tip, velocities were found to be $165 \mathrm{~cm} / \mathrm{s}$, a value some 33 times greater than the initial jet velocity [26].

In the numerical $\mathrm{CH}_{4}$-air flame studies, residence times and fuel consumption rates were the primary factors responsible for the differences in NO emission indices observed between fuel and air dilution. In the experimental $\mathrm{CH}_{4}$-air flames, all of the fuel is consumed, thus, we can eliminate fuel consumption rate as a factor. Similar to the numerical simulations, residence times are believed to be an important factor contributing to the differences in NO emissions in the experimental air- and fuel-diluted flames. In addition to residence times, temperature effects are also important in these experimental flames. In the following section, we will see that air dilution is not as effective as fuel dilution in decreasing in-flame soot, as a result, air-diluted flame temperatures are lower than the corresponding fuel-dihuted flame temperatures.

Due to the rapid acceleration of hot products in these $\mathbf{C H}_{4}$-air flames, it is reasonable to expect that longer flames will have greater velocities near the flame tip. Thus, we would expect that a longer flame would have shorter residence times associated with it. Figures 3.6 and 3.7 show the measured flame lengths for the room temperature and preheated reactant conditions respectively. Here we see that at equivalent dihent fractions, $Z$, the air-diluted flames are indeed longer than the fuel-diluted flames. The effect is more pronounced with the preheated flames, which also show a more significant difference in the $\mathrm{NO}_{\mathrm{x}}$ emission indices (cf Fig. 3.5). Therefore, the visibly longer air- 


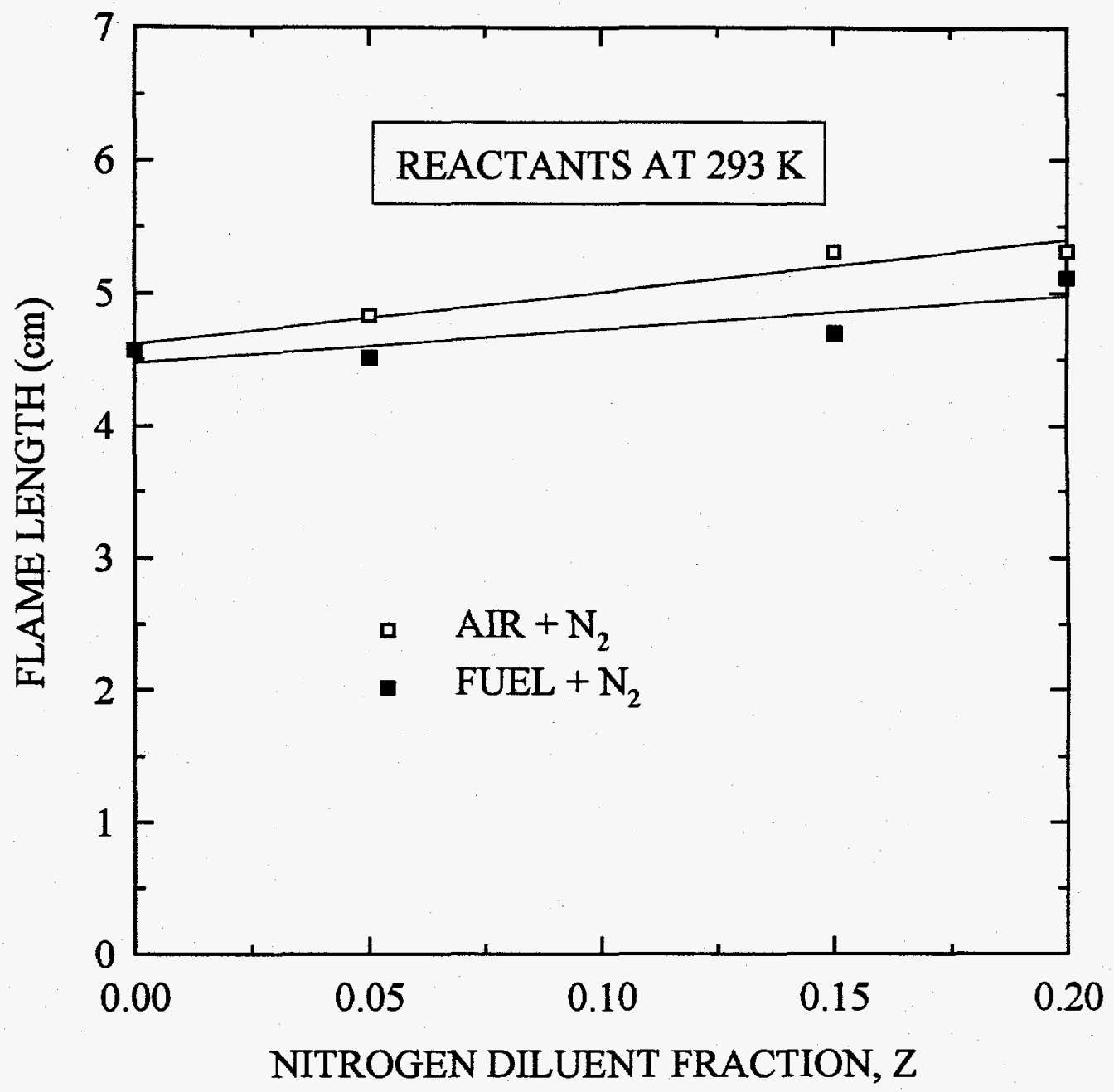

FIGURE 3.6. Visible flame lengths for laminar jet flames with various levels of $\mathrm{N}_{2}$ dilution in either the fuel or air stream. Reactants enter at $293 \mathrm{~K}$ with the fuel mass flowrate fixed at $3.0 \mathrm{mg} / \mathrm{s}$. 


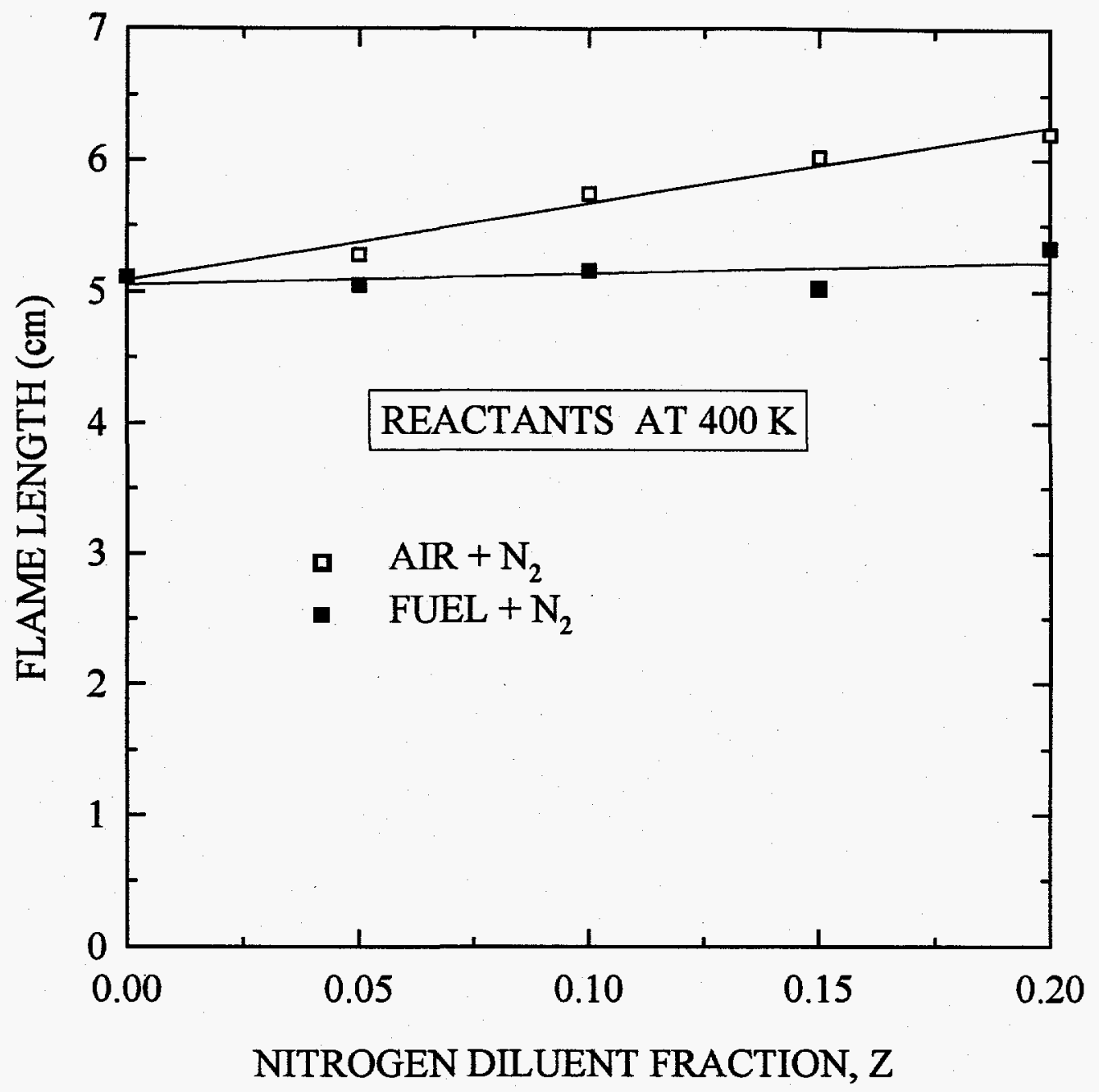

FIGURE 3.7. Visible flame lengths for laminar $\mathrm{CH}_{4}$-air jet flames with various levels of $\mathrm{N}_{2}$ dilution in either the fuel or air stream. Reactants enter at $400 \mathrm{~K}$ (nominal) with the fuel mass flowrate fixed at $3.3 \mathrm{mg} / \mathrm{s}$. 
diluted flames are expected to have somewhat shorter residence times which would contribute to the lower $\mathrm{NO}_{\mathrm{x}}$ emission indices observed in these flames.

Figures 3.8 and 3.9 show the ratio of the soot-free flame length to the total flame length versus diluent fraction, $Z$, for the room temperature and preheated flames, respectively. Here we see that fuel dilution ultimately eliminates all soot from the flame at $Z=0.15$ for the room temperature reactants (Fig. 3.8) and at $Z=0.2$ for the preheated reactants (Fig. 3.9). $\mathrm{N}_{2}$ dilution of the air stream, on the other hand, causes only a modest reduction in the amount of in-flame soot. The greater luminosity of the air-diluted flames implies that they may be cooler than the corresponding fuel-diluted flames due to radiative heat losses. The following section, which presents in-flame temperature measurements, confirms this speculation.

\subsubsection{Temperature Measurements}

Both axial and radial temperature profiles were taken in the preheated flames for the three cases of interest, no dilution, air dilution $(Z=0.15)$, and fuel dilution $(Z=0.15)$, to determine if the observed differences in soot are affecting the flame temperatures. The diluent fraction in the dihuted flames, $Z=0.15$, was chosen to match that of the numerical simulation previously discussed in detail.

Figure 3.10 shows the axial profiles obtained through the three flames of interest. In the lower region of the flame, $x<30 \mathrm{~mm}$, the fuel-diluted flame is considerably cooler, along the jet centerline, than the undiluted or air-diluted flames. This is due to the higher 


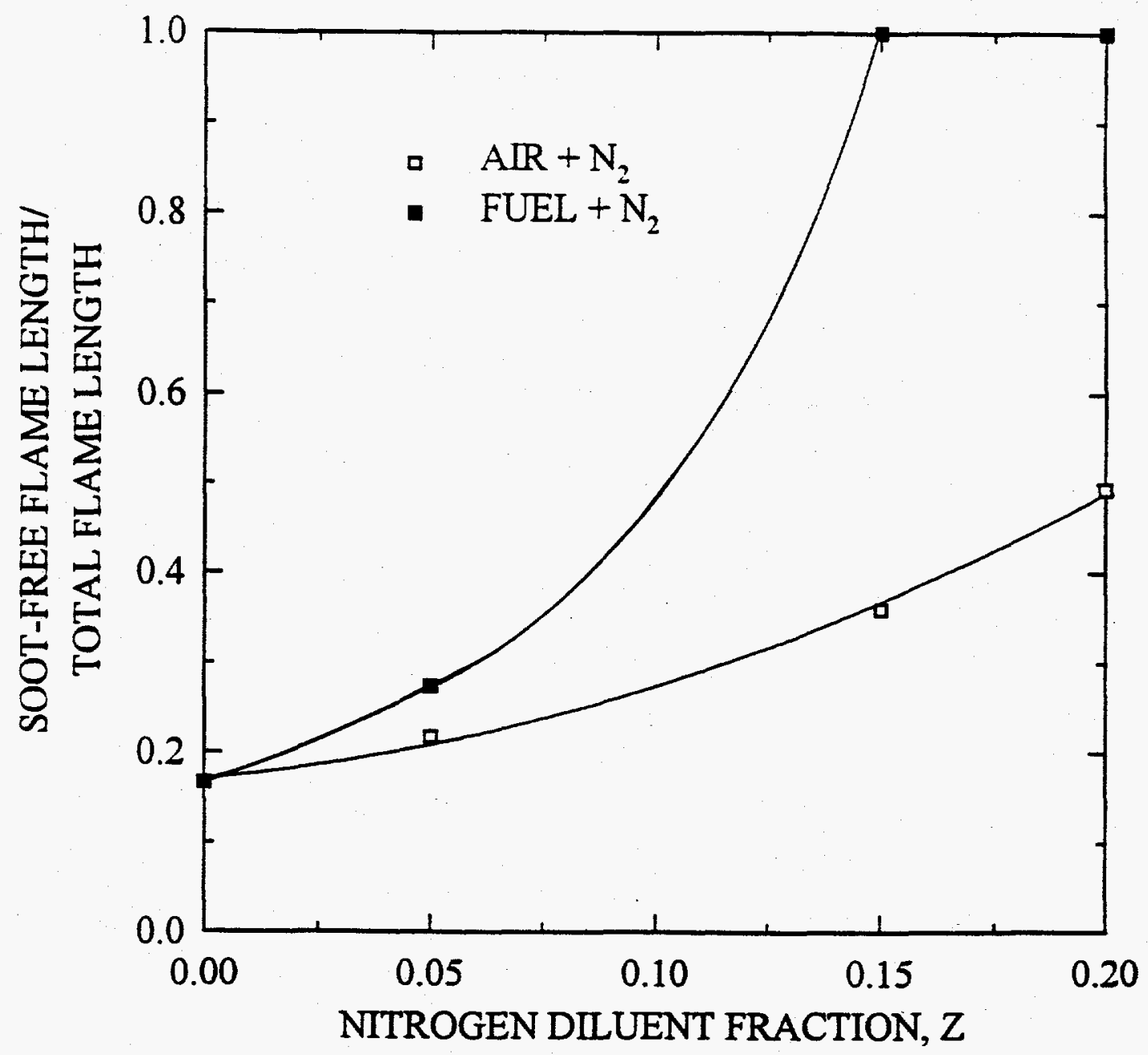

FIGURE 3.8. Fraction of the visible flame length that is soot-free (blue) with various levels of $\mathrm{N}_{2}$ dilution in either the fuel or air stream. Reactants enter at 293 $K$ with the fuel mass flowrate fixed at $3.0 \mathrm{mg} / \mathrm{s}$. 


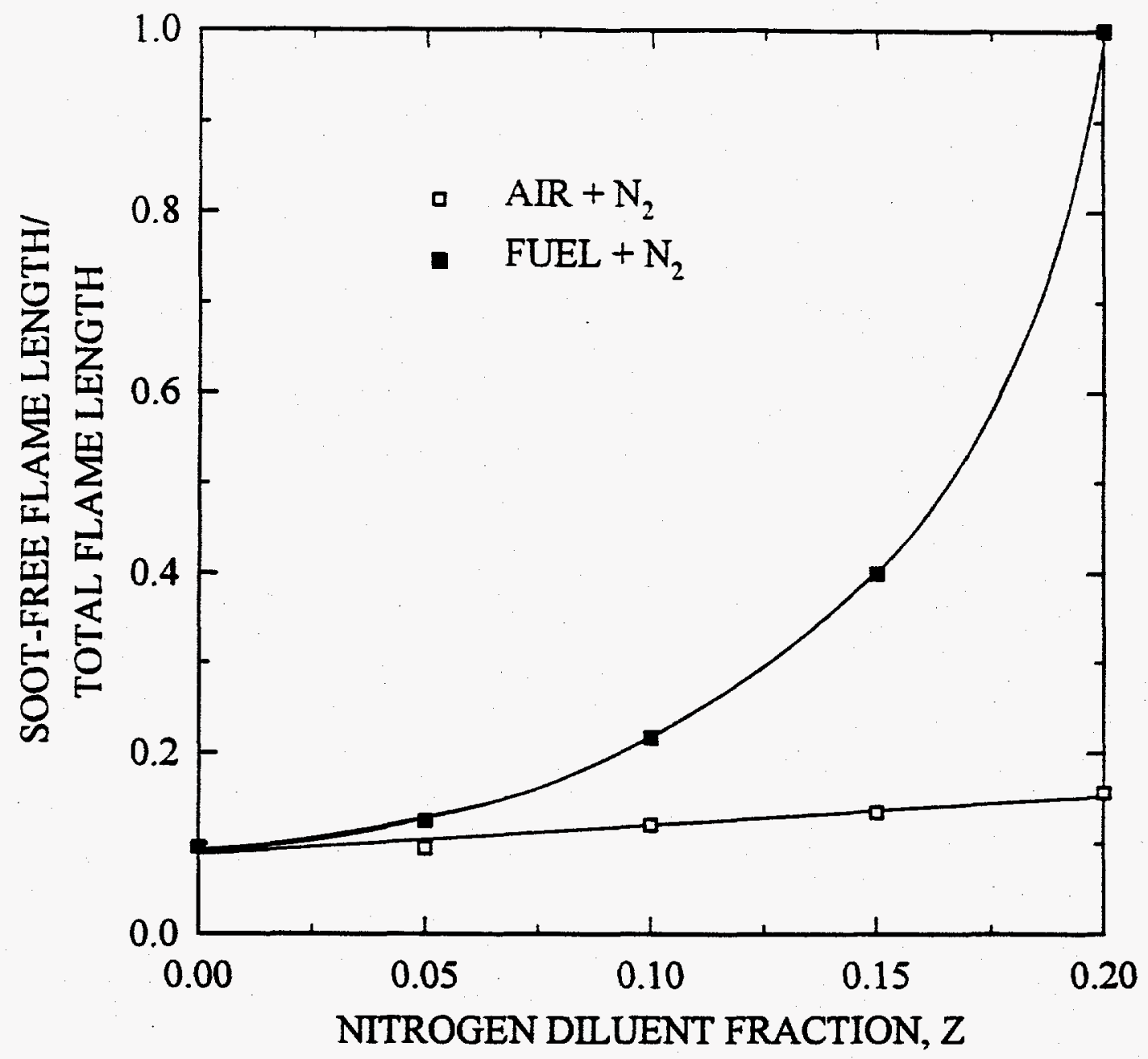

FIGURE 3.9. Fraction of the visible flame length that is soot-free (blue) with various levels of $\mathrm{N}_{2}$ dilution in either the fuel or air stream. Reactants enter at 400 $\mathrm{K}$ (nominal) with the fuel mass flowrate fixed at $3.3 \mathrm{mg} / \mathrm{s}$. 
exit velocity of the fuel stream, $u_{F, o}=20.0 \mathrm{~cm} / \mathrm{s}$ versus $u_{F, o}=7.8 \mathrm{~cm} / \mathrm{s}$ for the undiluted or air-diluted flames. For $x>30 \mathrm{~mm}$, we see that now the fuel-diluted flame is considerably hotter than the air-diluted flame. Although chemical effects may be important, it is believed that the higher fuel-diluted flame temperatures are a result of the decreased luminosity (in-situ soot) of this flame. The maximum flame temperatures shown in Fig. 3.10 are in close agreement with the visible flame lengths of these flames (cf. Fig. 3.7).

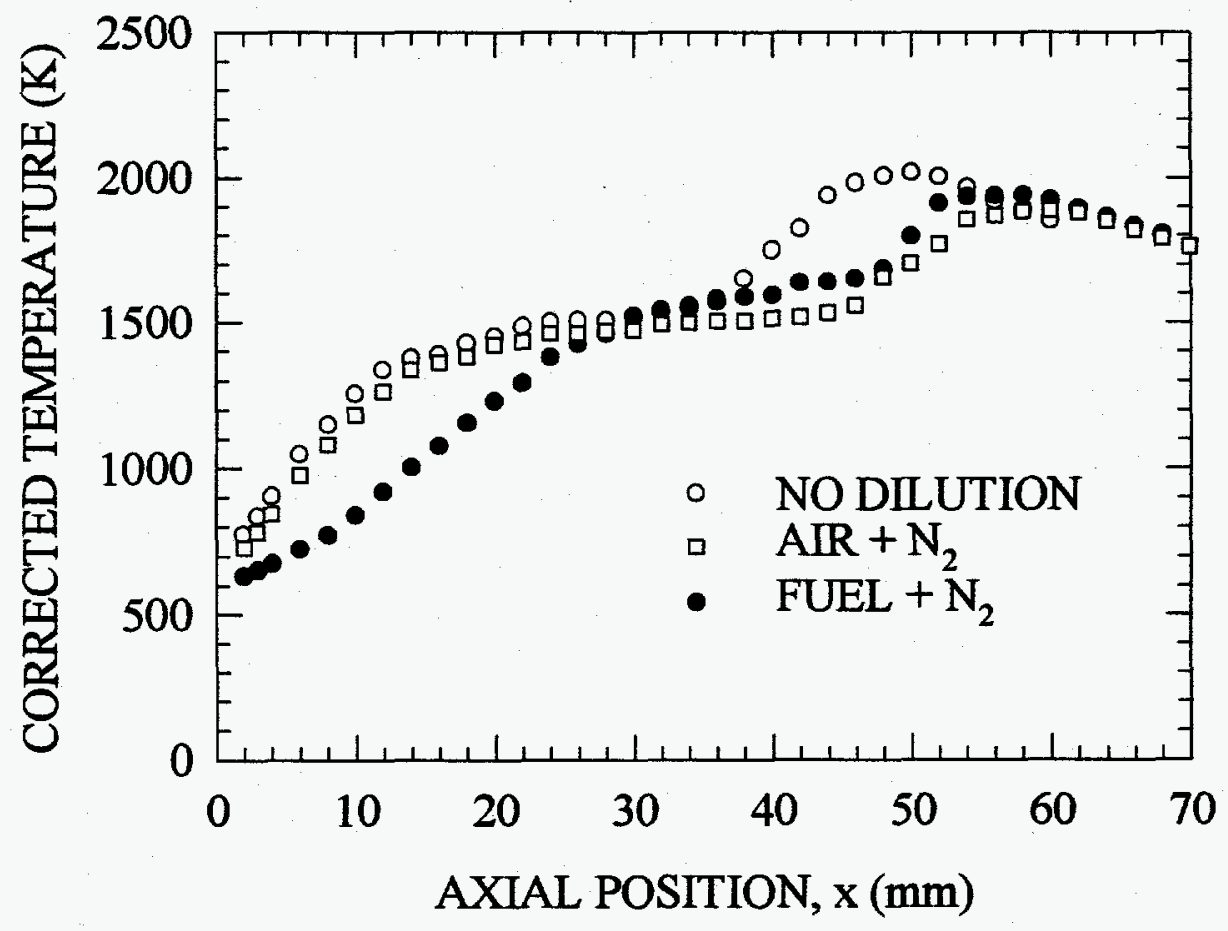

FIGURE 3.10. Axial temperature profiles along the jet centerline for undiluted, fueldiluted $(Z=0.15)$, and air-diluted $(Z=0.15)$ preheated $(400 \mathrm{~K})$ flames. 
Figures 3.11 through 3.14 show detailed radial temperature profiles through the three flames of interest at various heights above the burner exit. At a height of $5 \mathrm{~mm}$ in the flames (Fig. 3.11), we see that fuel dilution causes a substantial decrease in temperatures in the core of the jet, while air dilution causes only a modest decrease in flame temperatures below that of the undiluted flame. Also, we see that air and fuel dilution achieve roughly the same decrease in the peak flame temperature from the undiluted case, $\mathrm{T}=2200 \mathrm{~K}$, to approximately $2000 \mathrm{~K}$ in the flame zone. Similar trends can be seen in Fig. 3.12, which shows the radial profiles at a height of $25 \mathrm{~mm}$ in the flames. Again, air and fuel dilution achieve roughly the same decrease in peak flame temperatures, but now the fuel-diluted flame is only $70 \mathrm{~K}$ cooler than the air-diluted flame at the flame centerline.

Figure 3.13 shows the radial temperature profiles at a height of $50 \mathrm{~mm}$ in the flames, which corresponds to the tip of the undiluted flame as the profile indicates. The interesting feature is that now air dilution has a greater effectiveness than fuel dilution in reducing the peak flame temperatures, as well as the centerline temperature of the flame. Fig. 3.14 shows the temperature profiles in the vicinity of the flame tips for all three flames. Note that the undiluted, fuel-diluted, and air-diluted flame-tip profiles were taken at axial positions of 50,55 , and $60 \mathrm{~mm}$ above the burner exit, respectively, to coincide with the differing lengths of these flames as previously shown in Figs. 3.6 and 3.7. Here we see, once again, that air dilution has the greater effectiveness in decreasing the temperatures throughout the flame. 


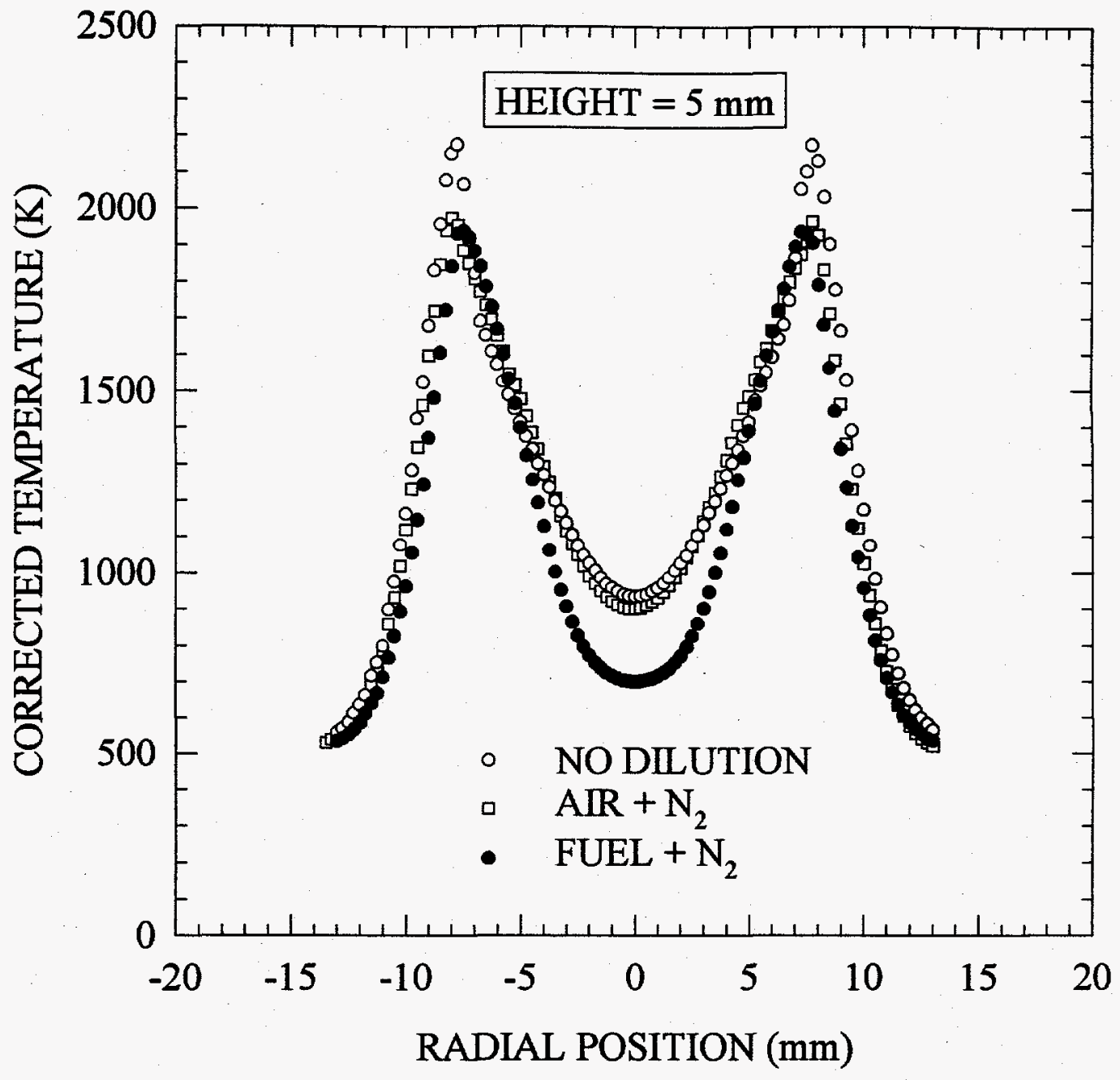

FIGURE 3.11. Radial temperature profiles for undihuted, fuel-diluted $(Z=0.15)$, and airdiluted $(Z=0.15)$ preheated $(400 \mathrm{~K}$ nominal) flames at a height of $5 \mathrm{~mm}$ above the fuel jet exit. 


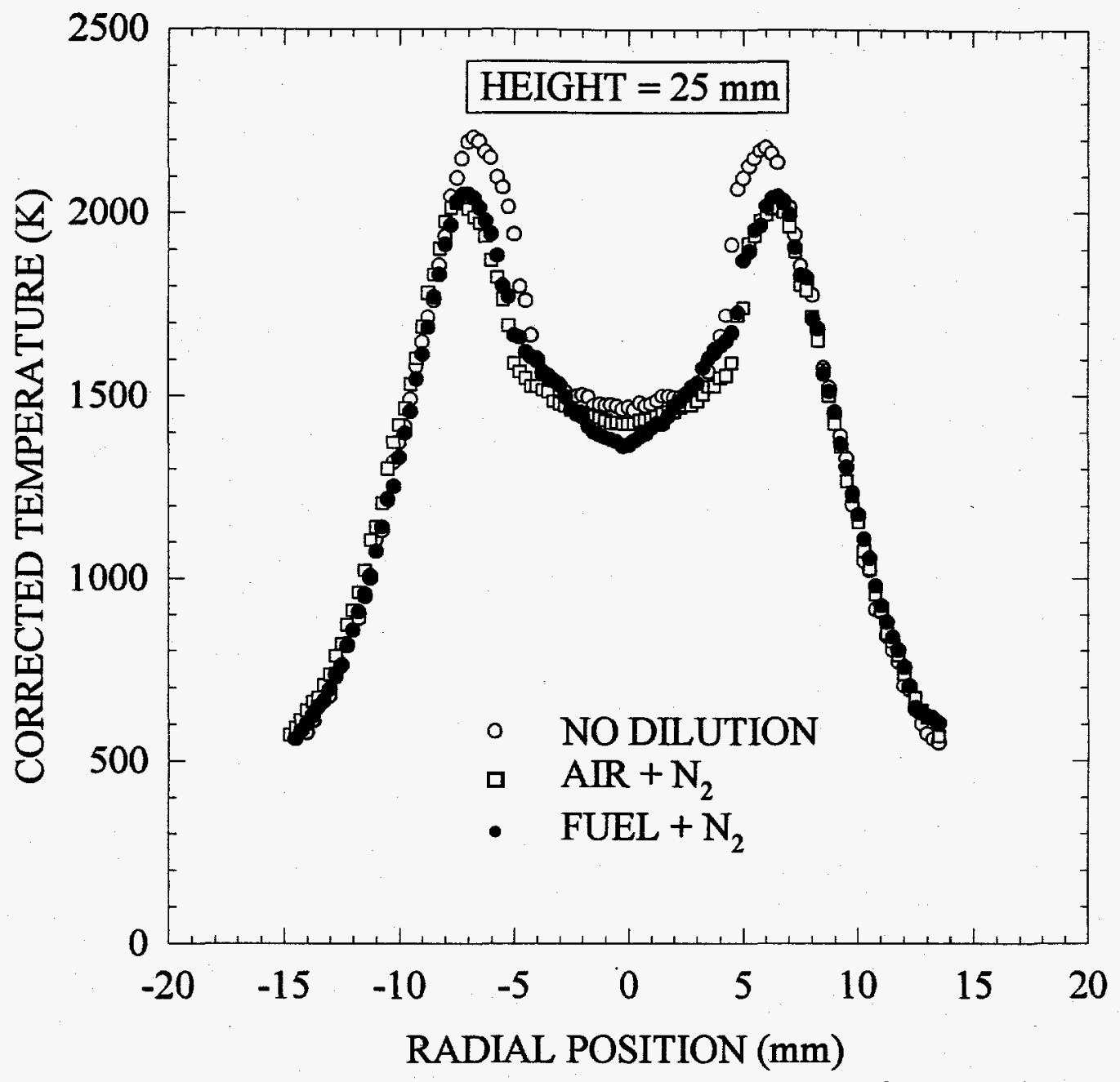

FIGURE 3.12. Radial temperature profiles for undiluted, fuel-diluted $(Z=0.15)$, and airdiluted $(Z=0.15)$ preheated ( $400 \mathrm{~K}$ nominal) flames at a height of $25 \mathrm{~mm}$ above the fuel jet exit. 


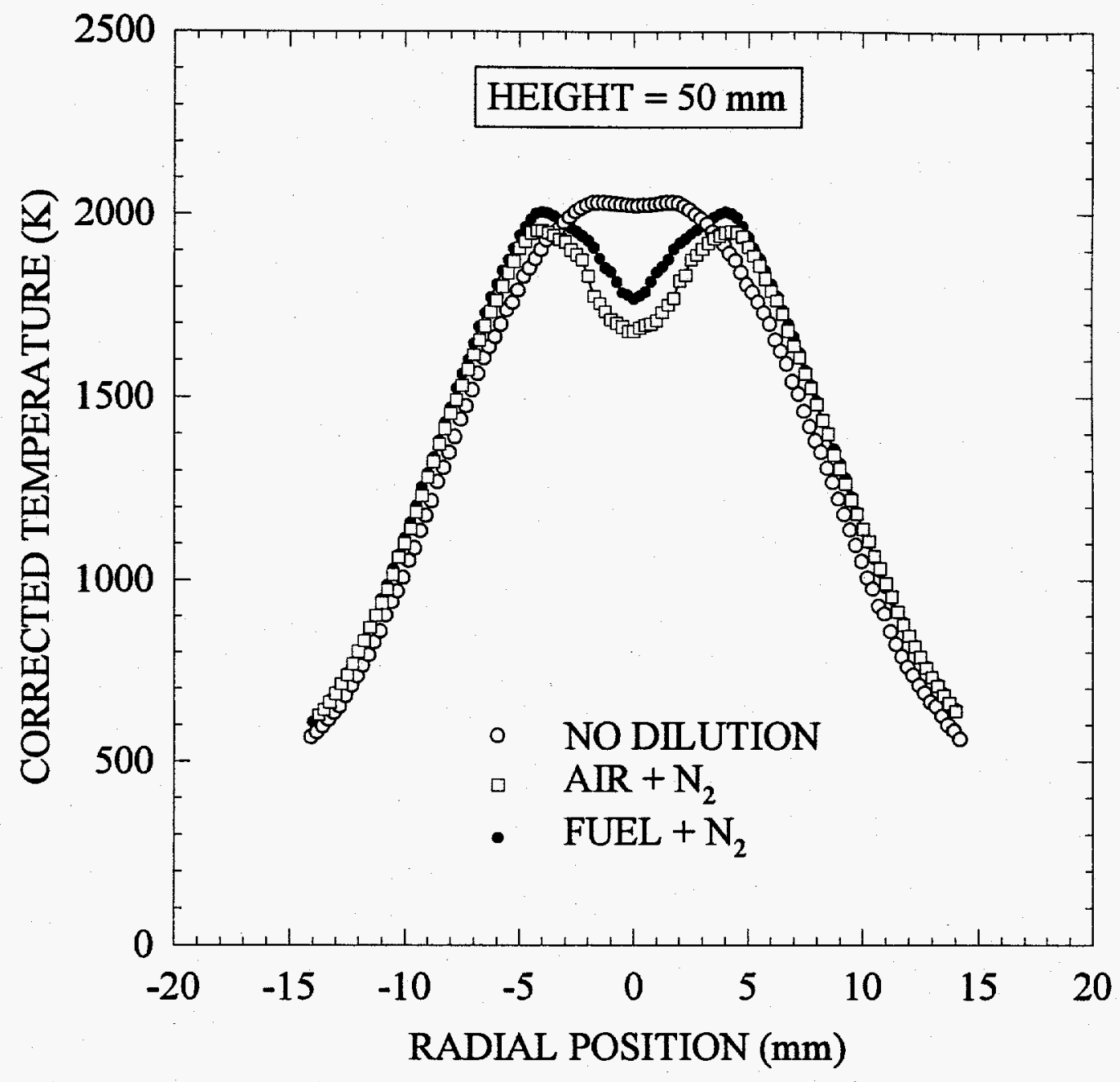

FIGURE 3.13. Radial temperature profiles for undiluted, fuel-diluted $(Z=0.15)$, and airdiluted $(Z=0.15)$ preheated $(400 \mathrm{~K}$ nominal) flames at a height of $50 \mathrm{~mm}$ above the fuel jet exit. 


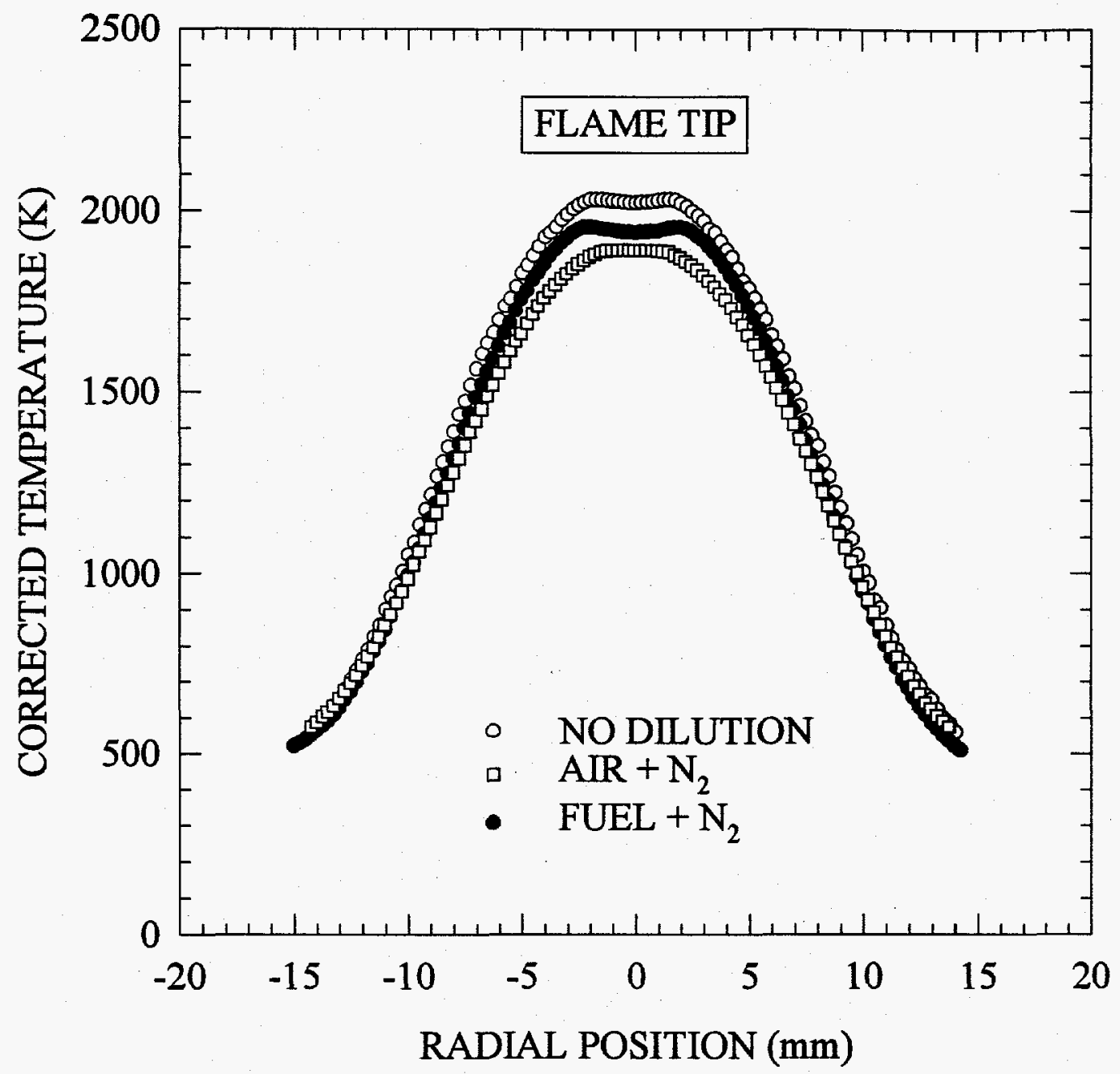

FIGURE 3.14. Radial temperature profiles at the visible flame tips for undiluted, fueldiluted $(Z=0.15)$, and air-diluted $(Z=0.15)$ preheated $(400 \mathrm{~K}$ nominal) flames. The axial positions are 50,55 , and $60 \mathrm{~mm}$ for the undiluted, fueldiluted, and air-diluted flames respectively. 
The differences in flame temperatures observed, especially in the upper regions of the flame where soot may be appreciable, correlate well with the differences in sooting propensity of these flames. This implies that the more luminous air-diluted flames are experiencing greater radiative heat losses, which result in the lower temperatures observed. The lower temperatures in the air-diluted flames, in turn, decrease thermal $\mathrm{NO}_{\mathrm{x}}$ production. It is possible that air dilution also results in shorter residence times, which further contributes to lowering thermal $\mathrm{NO}_{\mathrm{x}}$ production.

\subsection{2 $\mathrm{NO}_{2}$ and $\mathrm{CO}$ Measurements}

Figure 3.15 shows the $\mathrm{NO}_{2} / \mathrm{NO}_{\mathrm{x}}$ ratios obtained in the air- and fuel-diluted flames. The room temperature reactant flames generate slightly greater amounts of $\mathrm{NO}_{2}$ than the preheated flames. The $\mathrm{NO}_{2}$ proportion of the total $\mathrm{NO}_{\mathrm{x}}$ increases gradually with the addition of diluent $\mathbf{N}_{2}$. Although two curves are shown for the preheated flames, the differences between air and fuel dilution are within the statistical uncertainty of the data obtained. The $\mathrm{NO}_{2} / \mathrm{NO}_{\mathrm{x}}$ ratios here range from 0.16 to 0.23 , which are similar to measurements obtained from turbulent jet flames [29].

The CO emission indices (Fig. 3.16) increase with diluent fraction, $\mathrm{Z}$, as is typically found in practical applications of flue gas recirculation. Here we see the preheatedreactant, fuel-diluted flames produce slightly lower $\mathrm{CO}$ emissions than the corresponding preheated air-diluted flames. Also, the room temperature reactant flames show a larger increase in the $\mathrm{CO}$ emission index from the no dilution case, $\mathrm{Z}=0$, to the maximum 


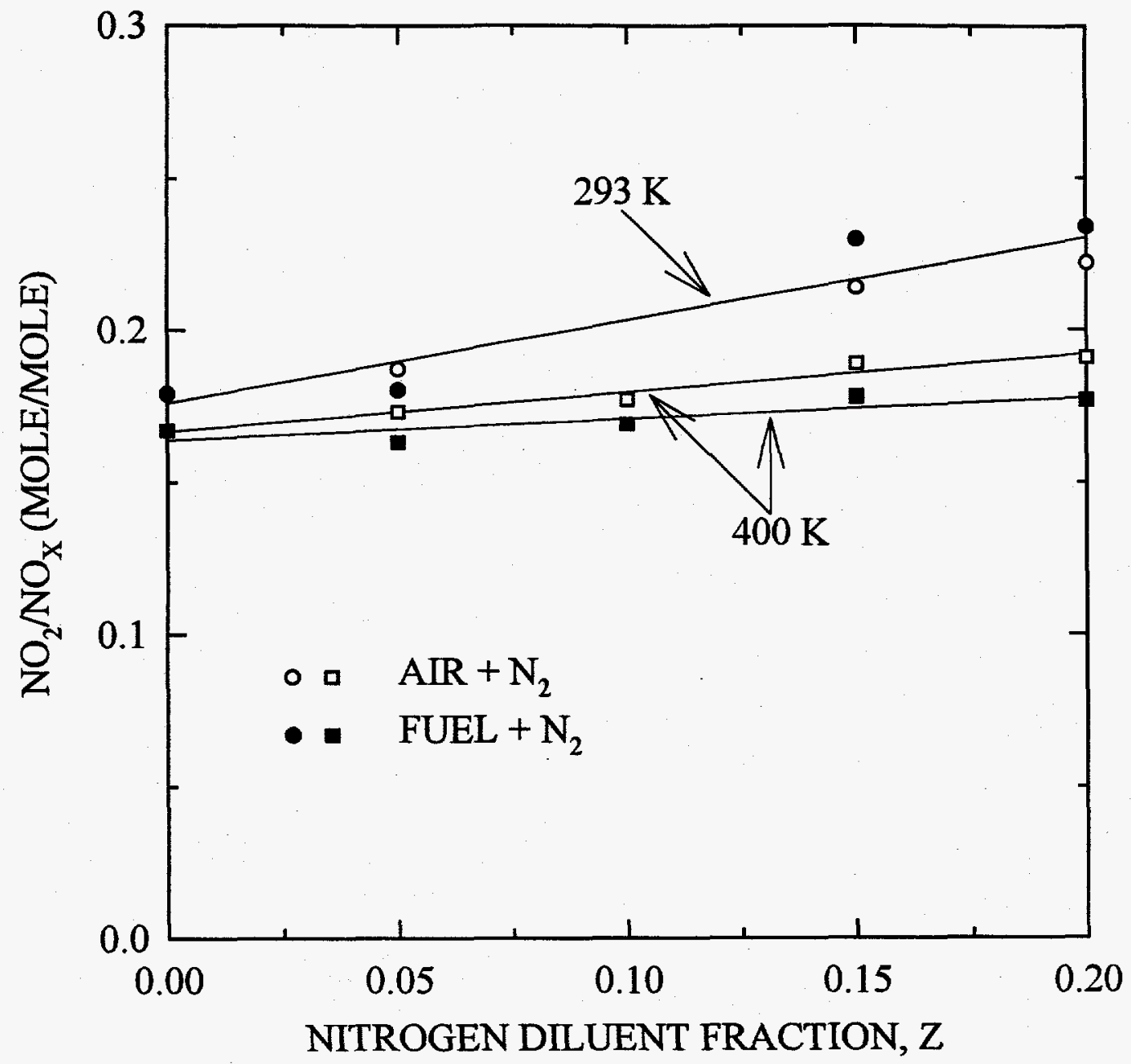

FIGURE 3.15. $\mathrm{NO}_{2}$-to $\mathrm{NO}_{\mathrm{x}}$ molar ratios for laminar jet flames with various levels of $\mathrm{N}_{2}$ dilution in either the fuel or air stream. 


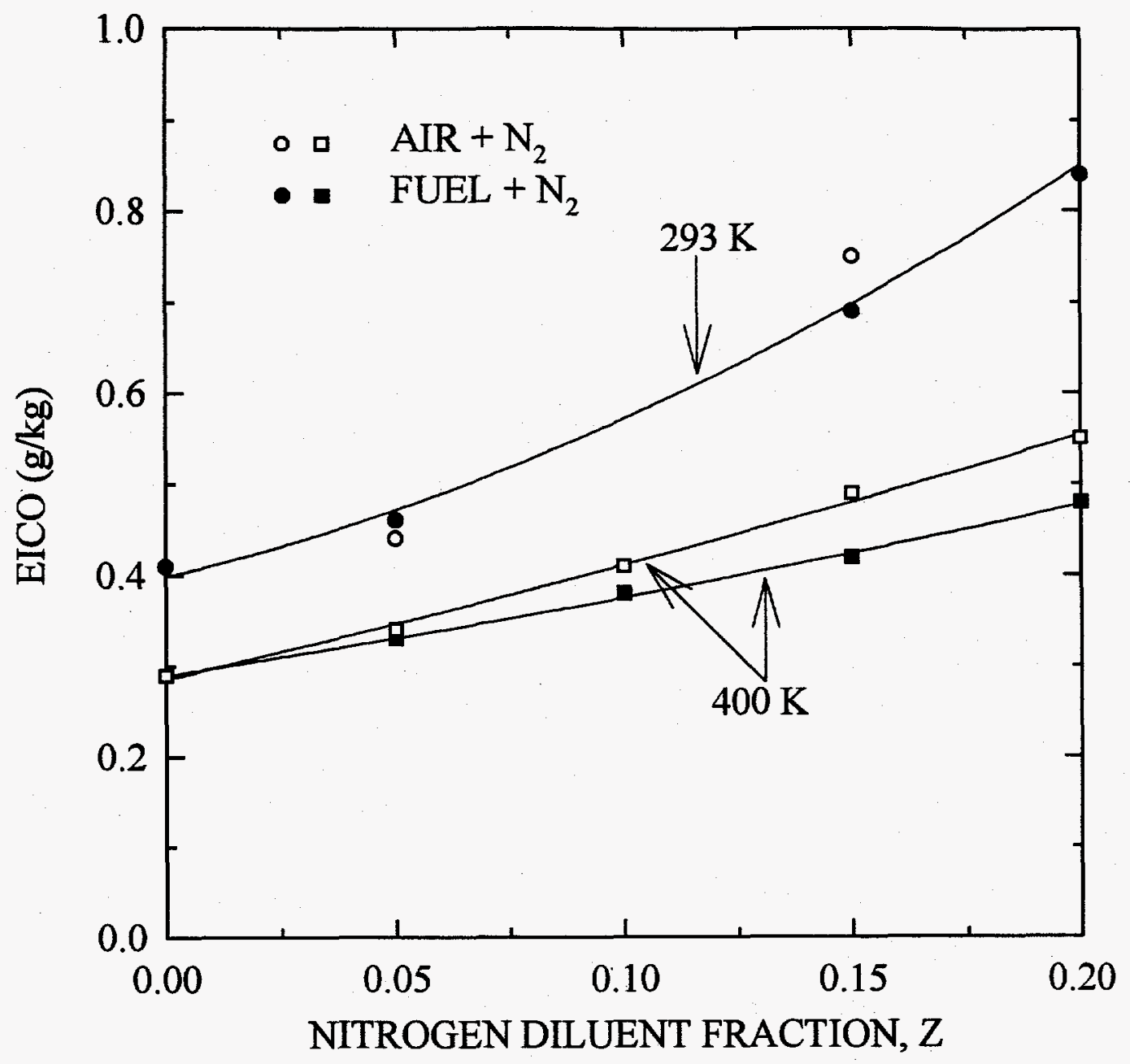

FIGURE 3.16. Carbon monoxide emission indices for laminar jet flames with various levels of $\mathrm{N}_{2}$ dilution in either the fuel or air stream. 
diluent fraction, $Z=0.2$ than the preheated reactant flames. The CO levels shown in Fig. 3.16 are also within the same range as those measured in turbulent $\mathrm{CH}_{4}$-air jet flames [30].

\subsubsection{Non-Sooting Diluted $\mathrm{CH}_{4}\left(\mathrm{~N}_{2}\right)$-Air Flames}

To determine if soot is responsible for the greater temperature depression, hence, lower thermal $\mathrm{NO}_{\mathrm{x}}$ production, associated with air dilution, a number of experiments were performed in which soot was eliminated from the flames. By eliminating in-flame soot, and, hence, differing degrees of heat loss, other potentially important factors, such as chemical kinetics, could be identified. As was previously noted, the preheated fuel-diluted flame with a diluent fraction $Z=0.2$ is entirely blue, indicating a lack of in-flame soot (cf. Fig. 3.9). This flame, therefore, was chosen as the baseline operating condition for the non-sooting fuel studies. To avoid ambiguity, we will refer to this fuel-diluted baseline mixture as $\mathrm{CH}_{4}\left(\mathrm{~N}_{2}\right)$ fuel. This new baseline condition is summarized in Table 3.2. From this baseline condition, air and fuel dilution are achieved in exactly the same manner as the previous experiments, that is, diluent $\mathrm{N}_{2}$ was added to the air stream to simulate $\mathrm{FGR}$, or to the fuel stream, still maintaining the fixed fuel mass flux condition, to simulate FIR. In all, five experimental data points were obtained for air and fuel dilution ranging from the baseline condition ( $\mathrm{Z}=0.2, \mathrm{CH}_{4}\left(\mathrm{~N}_{2}\right)$ fuel) to the maximum diluent fraction achieved, $\mathrm{Z}=$ 0.3 . 
TABLE 3.2. Baseline Non-Sooting Experimental Flame Condition, $\mathrm{CH}_{4}\left(\mathrm{~N}_{2}\right)$ Fuel.

$\begin{array}{lc}\mathrm{CH}_{4}\left(\mathrm{~N}_{2}\right) \text { Fuel Temperature }(\mathrm{K}) & 413 \\ \text { Air Temperature (K) } & 398 \\ \mathrm{CH}_{4} \text { Mass Fraction, } \mathrm{Y}_{\mathrm{CH}_{4}} & 0.216 \\ \mathrm{~N}_{2} \text { Mass Fraction, } \mathrm{Y}_{\mathrm{N} 2} & 0.784 \\ \mathrm{CH}_{4}\left(\mathrm{~N}_{2}\right) \text { Fuel Flowrate }(\mathrm{mg} / \mathrm{s}) & 15.3 \\ \text { Air Flowrate }(\mathrm{mg} / \mathrm{s}) & 243 \\ \text { Mean } \mathrm{CH}_{4}\left(\mathrm{~N}_{2}\right) \text { Fuel Velocity }(\mathrm{cm} / \mathrm{s}) & 24.1 \\ \text { Mean Air Velocity }(\mathrm{cm} / \mathrm{s}) & 3.5\end{array}$

Figure 3.17 shows the $\mathrm{NO}_{\mathrm{x}}$ emission indices obtained for these non-sooting $\mathrm{CH}_{4}\left(\mathrm{~N}_{2}\right)$ fuel flames. Note the abscissa scale, representing the diluent fraction, $\mathrm{Z}$, starts at $Z=0.2$ and extends to the maximum dilution level, $Z=0.3$. Here we see the air- and fueldiluted data points collapse onto a single curve indicating that air and fuel dilution are equally effective in reducing $\mathrm{NO}_{\mathrm{x}}$ emissions when soot is eliminated from the system. In addition to the elimination of soot in these experiments, it is observed that at equivalent diluent fractions, $Z$, the air- and fuel-diluted flames have nominally the same flame lengths; thus, residence times also should be nominally equal.

That the emission indices are now equal, for air and fuel dilution at equivalent diluent fractions, is an indication that the chemical kinetics are not changed significantly by where the diluent is introduced, i.e., the fuel stream or air stream. This further verifies the importance of the sooting propensity/temperature relationship found in the $\mathrm{CH}_{4}$-air flames, 


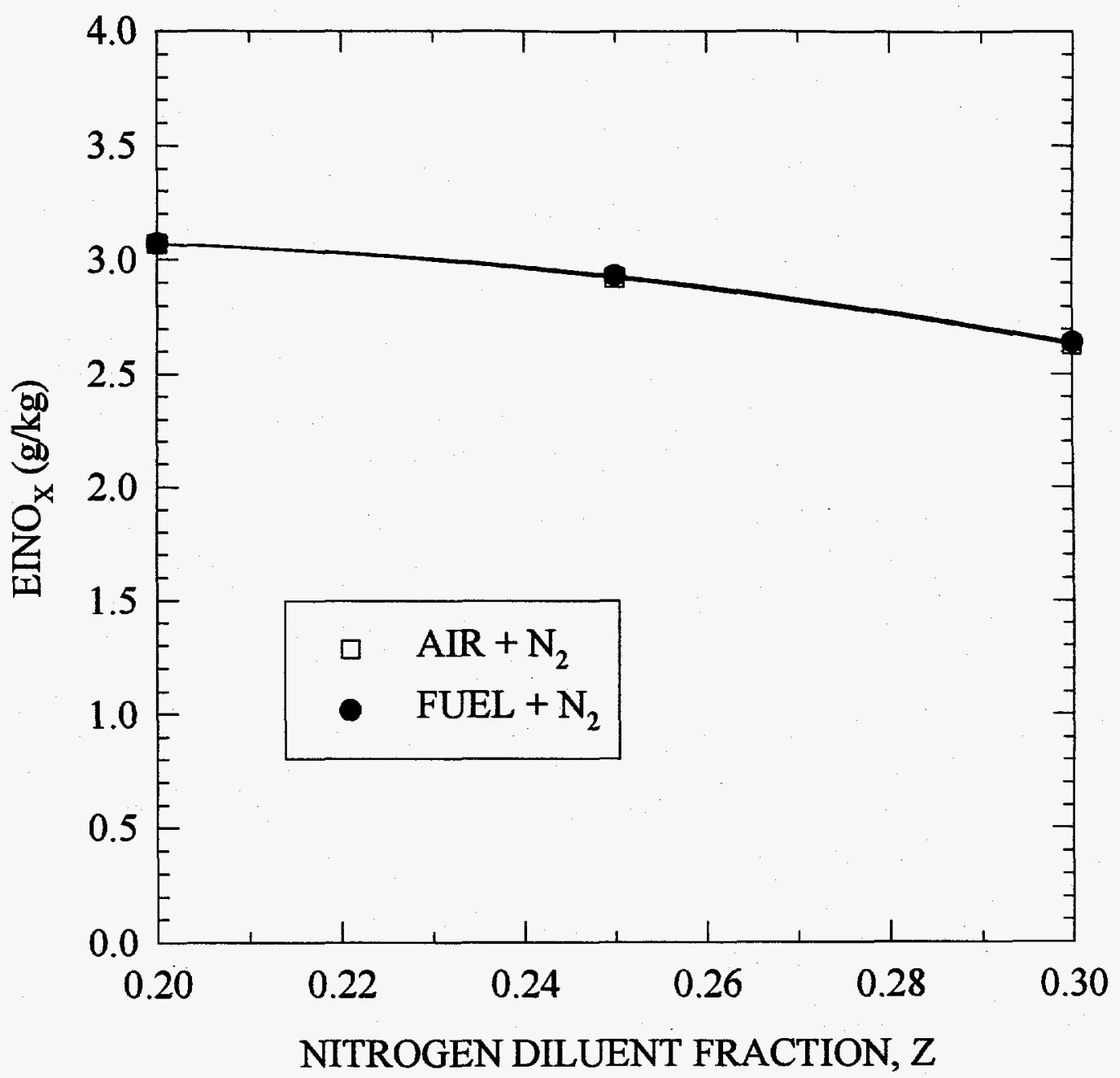

FIGURE 3.17. $\mathrm{NO}_{\mathrm{x}}$ emission indices for laminar non-sooting $\mathrm{CH}_{4}\left(\mathrm{~N}_{2}\right)$ jet flames with various levels of dilution in either the fuel or air stream starting from the nominally fuel-diluted, $\mathrm{Z}=0.2$, baseline condition. The $\mathrm{CH}_{4}\left(\mathrm{~N}_{2}\right)$ fuel flowrate is held constant as the diluent is added. 
where the air-diluted flames exhibited more soot, which directly contributed to lower flame temperatures due to radiative heat losses. As a result of the lower temperatures, less thermal NO was produced in these flames. 


\section{Chapter 4}

\section{SUMMARY AND CONCLUSIONS}

\subsection{Numerical Modeling}

Nonreacting $\mathrm{CH}_{4}$-air counterflows and $\mathrm{H}_{2}$-air and $\mathrm{CH}_{4}$-air counterflow flames were simulated. In these calculations, either the air stream or the fuel stream was diluted with $\mathrm{N}_{2}$ as a means of simulating some of the possible chemical and molecular transport effects related to the observed increased $\mathrm{NO}_{\mathrm{X}}$-reduction effectiveness of FIR over conventional FGR in practical applications. All conditions run were free from any heat losses through the boundaries. From these investigations, we draw the following conclusions:

- When the nozzle exit velocities are maintained at fixed values as $\mathrm{N}_{2}$ is added to either the air or fuel streams, fuel-side dilution results in somewhat higher NO emission indices than for air-side dilution. Detailed analysis of the results indicate that the higher NO emission index is a consequence of several countervailing effects. Although maximum flame temperatures are lower with fuel dilution, significantly increased residence times (e.g., $38 \%$ greater at $Z=0.15$ ) result in net NO production rates that are only slightly lower than with air dilution. Thus, the major factor causing 
the higher NO emission indices with fuel dilution is the decreased net fuel consumption rate, which, for example, is $16 \%$ less at the $Z=0.15$ condition.

- When the fuel mass flux is maintained constant as diluent is added to the fuel, and the air stream velocity is simultaneously increased to match that of the diluted fuel stream, NO emission indices are considerably lower than for equivalent air-side dilution. This case more realistically represents the situation in practice than does the fixed-velocity case above. For these condition, all major factors contributing to NO formation are affected: temperatures are lower, residence times are shorter, and the detailed chemical pathways producing NO are altered. For the fixed fuel mass flux condition, however, net fuel consumption rates for fuel dilution are significantly higher than for air dilution (e.g., $27 \%$ higher at $Z=1.15$ ). The decreased NO emission indices, therefore, are the result of both increased fuel consumption and considerably smaller net NO production rates, which, for example, is $42 \%$ less at $Z=0.15$. Thus, it appears that steeper gradients leading to greater fuel consumption and much reduced residence times for NO formation are the dominant factors in causing fuel dilution to be more effective than air dilution for these flow conditions.

\subsection{Experiments}

$\mathrm{NO}_{\mathrm{X}}$ and $\mathrm{CO}$ emission indices, $\mathrm{NO}_{2}$-to- $\mathrm{NO}_{\mathrm{X}}$ ratios, and visible and soot-free flame lengths associated with laminar $\mathrm{CH}_{4}$-air jet flames were measured for a variety of flame conditions. Experiments were conducted in which either the air stream or fuel stream was 
diluted with $\mathrm{N}_{2}$, with the range of diluent fractions nominally the same as in the numerical simulations. Conclusions drawn from these experiments are the following:

- Fuel-side dilution results in somewhat greater $\mathrm{NO}_{\mathrm{X}}$ emission indices than air-side dilution. The effect is more pronounced at the higher reactants temperature investigated ( $400 \mathrm{~K}$ versus $293 \mathrm{~K}$ ). Peak temperatures are also higher with fuel-side dilution.

- The higher $\mathrm{NO}_{\mathrm{x}}$ emissions with fuel-side dilution are likely a consequence of the higher peak temperatures. The higher temperatures, in turn, are thought to result from decreased radiation from the fuel-diluted flames since in situ soot formation is greatly diminished compared to equivalent air-diluted flames. Experiments conducted with flames having no in situ soot showed no differential effects on $\mathrm{NO}_{\mathrm{X}}$ reduction for fuel and air dilution, further supporting this hypothesis.

The conclusions drawn above clearly show that the location of diluent addition can affect molecular transport and chemical kinetic phenomena, depending on flow conditions. These effects are primarily manifested as changes in local residence times and temperatures. There was no evidence that addition of diluent to the fuel stream, per se, creates a chemical environment that is substantially different than adding diluent to the air stream. This suggests that the greater effectiveness of FIR over FGR in practical applications more likely results from differences in turbulent mixing and heat transfer, rather than fundamental differences in chemistry. 


\section{REFERENCES}

1. Hopkins, K. C., Czerniak, D. O., Radak, L., Youssef, C., and Nylander, J., 'NO Reduction on Natural Gas-Fired Boilers Using Fuel Injection Recirculation (FIR) Laboratory Demonstration," ASME Paper 91-JPGC-EC-3, presented at the International Power Generation Conference, San Diego, CA, October 6-10, 1991.

2. Miller, J. A. and Bowman, C. T., "Mechanism and Modeling of Nitrogen Chemistry in Combustion," Prog. Energy Comb. Sci., 15(4):287-338, 1984.

3. Williams, F. A., Turbulent Mixing in Non-Reactive \& Reactive Flows, Purdue University, S.N.B. Murthy, New York, Plenum Press, p. 189, 1975.

4. Turns, S. R., An Introduction to Combustion: Concepts and Applications, McGrawHill, New York, 1996.

5. Bowman, C. T., "Control of Combustion-Generated Nitrogen Oxide emissions: Technology Driven by Regulation," Twenty-Fourth Symposium (International) on Combustion, The Combustion Institute, Pittsburgh, pp. 859-878, 1992.

6. Hayhurst, A. N. and Vince, I. M., "Nitric Oxide Formation from $\mathrm{N}_{2}$ in Flames: The Importance of Prompt NO," Prog. Energy Combust. Sci. 6:35-51, 1980.

7. Flagan, R. C. and Seinfeld, J. H., Fundamentals of Air Pollution Engineering, Prentice Hall, Englewood Cliffs, NJ, 1988.

8. Fenimore, C. P., "Formation of Nitric Oxide in Premixed Hydrocarbon Flames," Thirteenth Symposium (International) on Combustion, The Combustion Institute, Pittsburgh, pp. 373-380, 1970.

9. Takeno, T., "NO Emission Characteristics and Formation Mechanisms of Methane Air Flames," Eighth International Symposium on Transport Phenomenon in Combustion, San Francisco, 1995.

10. Hahn, W. A., and Wendt, J. O. L., "NO ${ }_{x}$ Formation in Flat, Laminar, Opposed Jet Methane Diffusion Flames," Eighteenth Symposium (International) on Combustion, The Combustion Institute, Pittsburgh, pp. 121-131, 1981.

11. Levy, J. M., Longwell, J. L., Sarofim, A. F., Corley, T. L., Heap, M., and Tyson, T. J., "NOx Abatement in Fossil Fueled Combustion: Chemical Kinetic Considerations," Proc. of the Third Stationary Source Combustion Symposium, Vol. 4. Fundamental 
Combustion Research \& Environmental Assessment, Interagency Energy/Env. Res. \& Dev. Prog. Report No. EPA-600/7-79/050d, Feb., 1979.

12. Smooke, M. D., Puri, I. K, and Seshadri, K. "A Comparison Between Numerical Calculations and Experimental Measurements of the Structure of a Counterflow Diffusion Flame Burning Diluted Methane in Dihuted Air," Twenty-First Symposium (International) on Combustion, The Combustion Institute, Pittsburgh, pp. 1783-1792, 1986.

13. Nishioka, M., Nakagawa, S., Ishikawa, Y., Takeno, T., "NO Emission Characteristics of Methane-Air Double Flame," Combustion and Flame, 98:127-138, 1994.

14. Smyth, K. C., "NO Production and Destruction in a Methane/Air Diffusion Flame," Building and Fire Research Laboratory Report (Combustion Science and Technology in press, 1996).

15. Burke, S. P., and Schumann, T. E. W., "Diffusion Flames," Industrial and Engineering Chemistry, 20(10):998-1004, 1928.

16. Roper, F. G., "The Prediction of Laminar Jet Diffusion Flame Sizes: Part I. Theoretical Model," Combustion and Flame, 29:219-226, 1977.

17. Kee, R. J., Miller, J. A., Evans, G. H., and Dixon-Lewis, G., "A Computational Model of the Structure and Extinction of Strained Opposed Flow, Premixed Methane-Air Flames," Twenty-Second Symposium (International) on Combustion, The Combustion Institute, Pittsburgh, pp. 1479-1494, 1988.

18. Lutz, A. E., Kee, R. J., and Grcar, J. F., "Oppdif. A Fortran Program for Computing Opposed-Flow Diffusion Flames," Sandia National Laboratories Report (in press).

19. Kee, R. J., Rupley, F. M. and Miller, J. A., "Chemkin-II: A Fortran Chemical Kinetics Package for the Analysis of Gas-Phase Chemical Kinetics," Report No. SAND898009/UC-401, Sandia National Laboratories, March 1991.

20. Kee, R. J., Dixon-Lewis, G., Warnatz, J., Coltrin, M. E., and Miller, J. A., “A Fortran Computer Code Package for the Evaluation of Gas-Phase Multicomponent Transport Properties," Report No. SAND86-8246, Sandia National Laboratories, 1986.

21. Grcar, J. F., "The Twopnt Program for Boundary Value Problems," Report No. SAND91-8230, Sandia National Laboratories, April 1992.

22. Takeno, T., and Nishioka, M., "Species Conservation and Emission Indices for Flames Described by Similarity Solutions," Combustion and Flame, 92:465-468, 1993.

23. Glassman, I., Combustion, 2nd Ed., Academic Press, Orlando, 1987. 
24. Reese, J. L., et al., "Demonstration of Fuel Injection Recirculation (FIR) for $\mathrm{NO}_{\mathrm{x}}$ Emissions Control," American and Japanese Flame Research Council, Pacific Rim International Conference on Environmental Control of Combustion Processes, Maui, HI, October 16-20, 1994.

25. Drake, M. C., et al, "Superequilibrium and Thermal Nitric Oxide Formation in Turbulent Diffusion Flames," Combustion and Flame, 69:347-365, 1987.

26. Santoro, J. R, Yeh, T. T., Horvath, J. J., and Semerjian, H. G., "The Transport and Growth of Soot Particles in Laminar Diffusion Flames," Combustion Science and Technology, 53:89-115, 1987.

27. Santoro, J. R., Semerjian, H. G., and Dobbins, R. A., "Soot Particle Measurements in Diffusion Flames," Combustion and Flame, 51:203-218, 1983.

28. Richardson, T. F., The Effects of Temperature, Fuel Concentration, and Fuel Molecular Structure on Soot Formation in Laminar Diffusion Flames, Ph. D. Thesis, The Pennsylvania State University, 1993.

29. Turns, S. R, and Bandaru, R. V., "Oxides of Nitrogen Emissions from Turbulent Hydrocarbon/Air Jet Diffusion Flames," Final Report - Phase II, GRI 92/0470, September 1992.

30. Turns, S. R and Bandaru, R. V., "Carbon Monoxide Emissions from Turbulent Nonpremixed Jet Flames," Combustion and Flame, 94:462-468, 1993.

31. Bradley, D., and Matthews, K. J., "Measurement of High Gas Temperatures with Fine Wire Thermocouples," Journal of Mechanical Engineering Sci., 10(4):299-305, 1968.

32. Modest, M. F., Radiative Heat Transfer, McGraw-Hill, New York, 1993.

33. Eckert, E. R. G., and Drake, R. M., Analysis of Heat and Mass Transfer, McGrawHill, New York, 1972. 


\title{
Appendix A
}

\section{REACTION MECHANISMS}

\section{A.1 $\mathrm{H}_{2}$-Air Chemical Kinetic Mechanism}

\author{
ELEMENTS \\ $\mathrm{H} O \mathrm{~N}$ \\ END \\ SPECIES \\ $\mathrm{H} 2 \mathrm{H} \mathrm{O}_{2} \mathrm{O} \mathrm{OH} \mathrm{HO} 2 \mathrm{H} 2 \mathrm{O} 2 \mathrm{H} 2 \mathrm{O}$ N2 $\mathrm{N}$ NO \\ END
}

REACTIONS

ARRHENIUS RATE COEFFICIENTS FOR THE

THREE-PARAMETER FUNCTIONAL FORM:

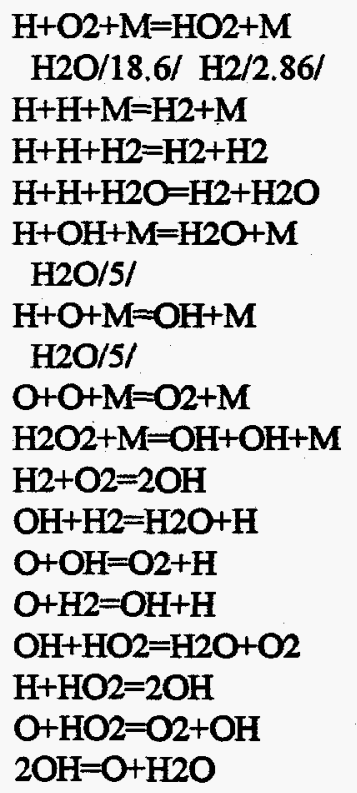

\begin{tabular}{|c|c|c|c|c|}
\hline & $\begin{array}{l}\frac{A_{i} \text { (Units }}{\text { Depend on }} \\
\text { Reaction) }\end{array}$ & $\beta_{i}$ & $\begin{array}{l}\underline{E}_{i} \\
\text { al/mole) }\end{array}$ & \\
\hline $\begin{array}{l}\mathrm{H}+\mathrm{O} 2+\mathrm{M}=\mathrm{HO} 2+\mathrm{M} \\
\mathrm{H} 2 \mathrm{O} / 18.6 / \mathrm{H} 2 / 2.86 /\end{array}$ & $3.61 \mathrm{E} 17$ & -0.72 & 0. & !DIXON-LEWIS \\
\hline $\mathrm{H}+\mathrm{H}+\mathrm{M}=\mathrm{H} 2+\mathrm{M}$ & $1.0 \mathrm{E} 18$ & -1.0 & 0. & !D-L \\
\hline $\mathrm{H}+\mathrm{H}+\mathrm{H}_{2}=\mathrm{H} 2+\mathrm{H} 2$ & $9.2 \mathrm{E} 16$ & -0.6 & 0. & \\
\hline $\mathrm{H}+\mathrm{H}+\mathrm{H} 2 \mathrm{O}=\mathrm{H} 2+\mathrm{H} 2 \mathrm{O}$ & $6.0 \mathrm{E} 19$ & -1.25 & 0. & \\
\hline $\begin{array}{l}\mathrm{H}+\mathrm{OH}+\mathrm{M}=\mathrm{H} 2 \mathrm{O}+\mathrm{M} \\
\mathrm{H} 2 \mathrm{O} / 5 /\end{array}$ & $1.6 \mathrm{E} 22$ & -2.0 & 0. & !D-L \\
\hline $\begin{array}{l}\mathrm{H}+\mathrm{O}+\mathrm{M}=\mathrm{OH}+\mathrm{M} \\
\mathrm{H} 2 \mathrm{O} / 5 /\end{array}$ & $6.2 \mathrm{E} 16$ & -0.6 & 0. & !D-L \\
\hline $\mathrm{O}+\mathrm{O}+\mathrm{M}=\mathrm{O} 2+\mathrm{M}$ & $1.89 \mathrm{E} 13$ & 0.0 & -1788 . & !NBS \\
\hline $\mathrm{H} 2 \mathrm{O} 2+\mathrm{M}=\mathrm{OH}+\mathrm{OH}+\mathrm{M}$ & 1.3E17 & 0.0 & 45500. & \\
\hline $\mathrm{H} 2+\mathrm{O} 2=2 \mathrm{OH}$ & $1.7 \mathrm{E} 13$ & 0.0 & 47780 . & \\
\hline $\mathrm{OH}+\mathrm{H} 2=\mathrm{H} 2 \mathrm{O}+\mathrm{H}$ & $1.17 \mathrm{E} 9$ & 1.3 & 3626. & !D-L\$W \\
\hline $\mathrm{O}+\mathrm{OH}=\mathrm{O} 2+\mathrm{H}$ & $3.61 \mathrm{E} 14$ & -0.5 & 0. & !JAM 1986 \\
\hline $\mathrm{O}+\mathrm{H} 2=\mathrm{OH}+\mathrm{H}$ & $5.06 \mathrm{E} 4$ & 2.67 & 6290. & !KLEMM,ET AL 1986 \\
\hline $\mathrm{OH}+\mathrm{HO} 2=\mathrm{H} 2 \mathrm{O}+\mathrm{O} 2$ & 7.5E12 & 0.0 & 0.0 & !D-L \\
\hline $\mathrm{H}+\mathrm{HO}_{2}=2 \mathrm{OH}$ & $1.4 \mathrm{E} 14$ & 0.0 & 1073. & !D-L \\
\hline $\mathrm{O}+\mathrm{HO}_{2}=\mathrm{O} 2+\mathrm{OH}$ & $1.4 \mathrm{E} 13$ & 0.0 & 1073. & !D-L \\
\hline $2 \mathrm{OH}=\mathrm{O}+\mathrm{H} 2 \mathrm{O}$ & $6.0 \mathrm{E}+8$ & 1.3 & 0. & ICOHEN-WEST. \\
\hline
\end{tabular}




$\begin{array}{lllll}\mathrm{H}+\mathrm{HO} 2=\mathrm{H} 2+\mathrm{O} 2 & 1.25 \mathrm{E} 13 & 0.0 & 0 . & \text { !D-L } \\ \mathrm{HO} 2+\mathrm{HO} 2=\mathrm{H} 2 \mathrm{O} 2+\mathrm{O} 2 & 2.0 \mathrm{E} 12 & 0.0 & 0 . \\ \mathrm{H} 2 \mathrm{O} 2+\mathrm{H}=\mathrm{HO} 2+\mathrm{H} 2 & 1.6 \mathrm{E} 12 & 0.0 & 3800 . \\ \mathrm{H} 2 \mathrm{O} 2+\mathrm{OH}=\mathrm{H} 2 \mathrm{O}+\mathrm{HO} 2 & 1.0 \mathrm{E} 13 & 0.0 & 1800 . \\ \mathrm{O}+\mathrm{N} 2=\mathrm{NO}+\mathrm{N} & 1.4 \mathrm{E} 14 & 0.0 & 75800 . \\ \mathrm{N}+\mathrm{O} 2=\mathrm{NO}+\mathrm{O} & 6.40 \mathrm{E} 9 & 1.0 & 6280 . \\ \mathrm{OH}+\mathrm{N}=\mathrm{NO}+\mathrm{H} & 4.0 \mathrm{E} 13 & 0.0 & 0 .\end{array}$

\section{A.2 Miller-Bowman (CH4-Air) Chemical Kinetic Mechanism}

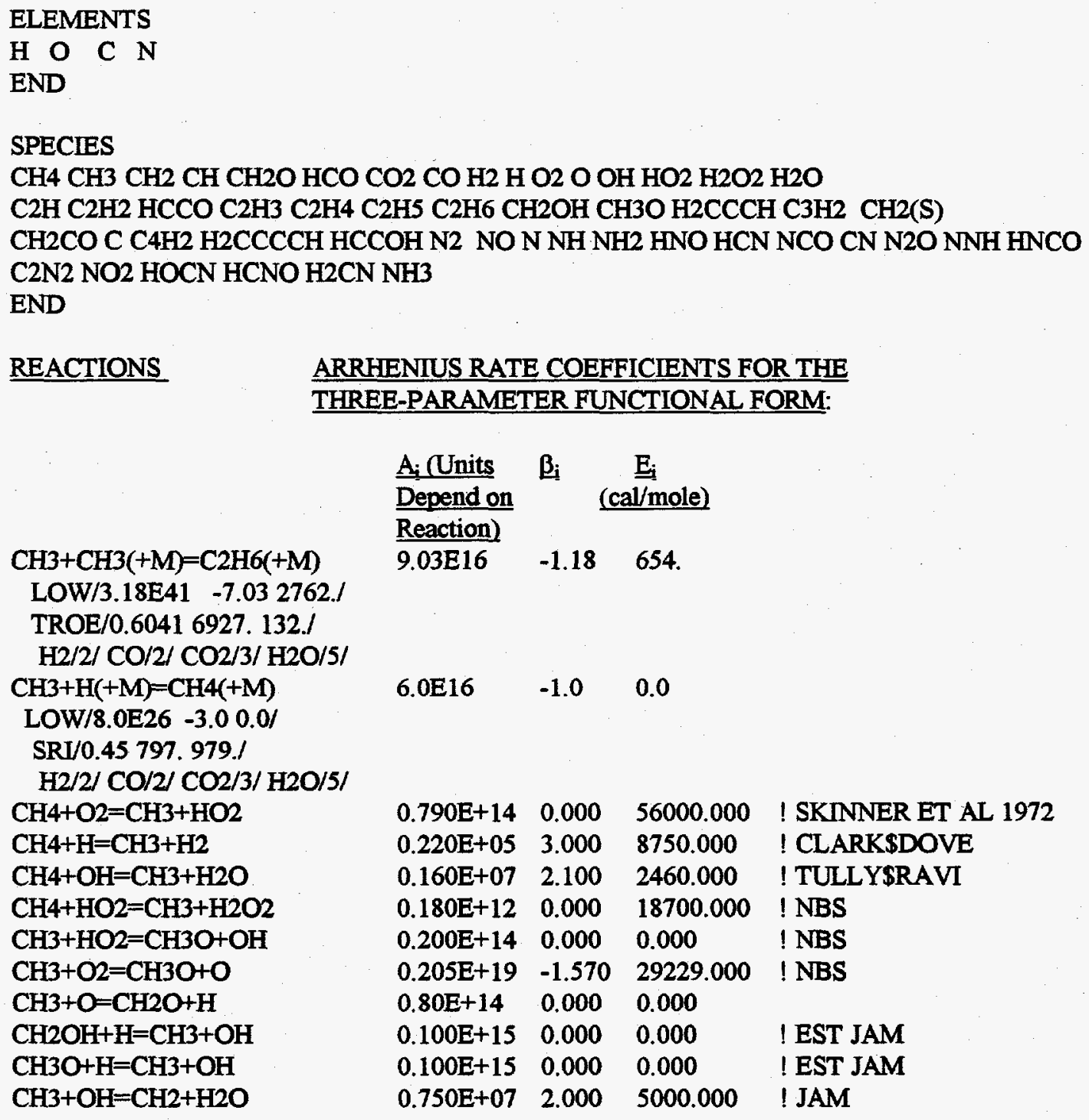

$\begin{array}{llll}0.790 \mathrm{E}+14 & 0.000 & 56000.000 & \text { ! SKINNER ET AL } 1972 \\ 0.220 \mathrm{E}+05 & 3.000 & \mathbf{8 7 5 0 . 0 0 0} & \text { ! CLARKSDOVE } \\ 0.160 \mathrm{E}+07 & 2.100 & 2460.000 & \text { ! TULLYSRAVI } \\ 0.180 \mathrm{E}+12 & 0.000 & \mathbf{1 8 7 0 0 . 0 0 0} & \text { ! NBS } \\ 0.200 \mathrm{E}+14 & 0.000 & 0.000 & \text { ! NBS } \\ 0.205 \mathrm{E}+19 & -1.570 & 29229.000 & \text { ! NBS } \\ 0.80 \mathrm{E}+14 & 0.000 & 0.000 & \\ 0.100 \mathrm{E}+15 & 0.000 & 0.000 & \text { ! EST JAM } \\ 0.100 \mathrm{E}+15 & 0.000 & 0.000 & \text { ! EST JAM } \\ 0.750 \mathrm{E}+07 & 2.000 & 5000.000 & \text { ! JAM }\end{array}$




\begin{tabular}{|c|c|c|c|c|}
\hline $\mathrm{CH} 3+\mathrm{H}=\mathrm{CH} 2+\mathrm{H} 2$ & $0.900 \mathrm{E}+14$ & 0.000 & 15100.000 & ! PG \\
\hline $\mathrm{CH} 3 \mathrm{O}+\mathrm{M}=\mathrm{CH} 2 \mathrm{O}+\mathrm{H}+\mathrm{M}$ & $0.100 E+15$ & 0.000 & 25000.000 & ! PG \\
\hline $\mathrm{CH} 2 \mathrm{OH}+\mathrm{M}=\mathrm{CH} 2 \mathrm{O}+\mathrm{H}+\mathrm{M}$ & $0.100 \mathrm{E}+15$ & 0.000 & 25000.000 & \\
\hline $\mathrm{CH} 3 \mathrm{O}+\mathrm{H}=\mathrm{CH} 2 \mathrm{O}+\mathrm{H} 2$ & $0.200 \mathrm{E}+14$ & 0.000 & 0.000 & ! PG \\
\hline $\mathrm{CH} 2 \mathrm{OH}+\mathrm{H}=\mathrm{CH} 2 \mathrm{O}+\mathrm{H} 2$ & $0.200 \mathrm{E}+14$ & 0.000 & 0.000 & \\
\hline $\mathrm{CH} 3 \mathrm{O}+\mathrm{OH}=\mathrm{CH} 2 \mathrm{O}+\mathrm{H} 2 \mathrm{O}$ & $0.100 \mathrm{E}+14$ & 0.000 & 0.000 & ! PG \\
\hline $\mathrm{CH} 2 \mathrm{OH}+\mathrm{OH}=\mathrm{CH} 2 \mathrm{O}+\mathrm{H} 2 \mathrm{O}$ & $0.100 \mathrm{E}+14$ & 0.000 & 0.000 & \\
\hline $\mathrm{CH} 3 \mathrm{O}+\mathrm{O}=\mathrm{CH} 2 \mathrm{O}+\mathrm{OH}$ & $0.100 E+14$ & 0.000 & 0.000 & ! PG \\
\hline $\mathrm{CH} 2 \mathrm{OH}+\mathrm{O}=\mathrm{CH} 2 \mathrm{O}+\mathrm{OH}$ & $0.100 \mathrm{E}+14$ & 0.000 & 0.000 & \\
\hline $\mathrm{CH} 3 \mathrm{O}+\mathrm{O} 2=\mathrm{CH} 2 \mathrm{O}+\mathrm{HO} 2$ & $0.630 \mathrm{E}+11$ & 0.000 & 2600.000 & ! PG \\
\hline $\mathrm{CH} 2 \mathrm{OH}+\mathrm{O}_{2}=\mathrm{CH} 2 \mathrm{O}+\mathrm{HO}_{2}$ & $0.148 \mathrm{E}+14$ & 0.000 & 1500.000 & ! CODATA,EA ASSUMED \\
\hline $\mathrm{CH} 2+\mathrm{H}=\mathrm{CH}+\mathrm{H} 2$ & $0.100 \mathrm{E}+19$ & -1.560 & 0.000 & ! THORNE,ET AL \\
\hline $\mathrm{CH} 2+\mathrm{OH}=\mathrm{CH}+\mathrm{H} 2 \mathrm{O}$ & $0.113 E+08$ & 2.000 & 3000.000 & I JAM \\
\hline $\mathrm{CH} 2+\mathrm{OH}=\mathrm{CH} 2 \mathrm{O}+\mathrm{H}$ & $0.250 \mathrm{E}+14$ & 0.000 & 0.000 & ! PG \\
\hline $\mathrm{CH}+\mathrm{O} 2=\mathrm{HCO}+\mathrm{O}$ & $0.330 E+14$ & 0.000 & 0.000 & ! PG \\
\hline $\mathrm{CH}+\mathrm{O}=\mathrm{CO}+\mathrm{H}$ & $0.570 \mathrm{E}+14$ & 0.000 & 0.000 & ! PG \\
\hline $\mathrm{CH}+\mathrm{OH}=\mathrm{HCO}+\mathrm{H}$ & $0.300 E+14$ & 0.000 & 0.000 & ! PG \\
\hline $\mathrm{CH}+\mathrm{CO} 2=\mathrm{HCO}+\mathrm{CO}$ & $0.340 \mathrm{E}+13$ & 0.000 & 690.000 & ! PG \\
\hline $\mathrm{CH}+\mathrm{H}=\mathrm{C}+\mathrm{H} 2$ & $0.150 \mathrm{E}+15$ & 0.000 & 0.000 & ! THORNE \\
\hline $\mathrm{CH}+\mathrm{H} 2 \mathrm{O}=\mathrm{CH} 2 \mathrm{O}+\mathrm{H}$ & $1.17 \mathrm{E}+15$ & -0.750 & 0.000 & ! JAM,LIN \\
\hline $\mathrm{CH}+\mathrm{CH} 2 \mathrm{O}=\mathrm{CH} 2 \mathrm{CO}+\mathrm{H}$ & $0.946 \mathrm{E}+14$ & 0.000 & -515.000 & ! THORNE \\
\hline $\mathrm{CH}+\mathrm{C} 2 \mathrm{H} 2=\mathrm{C} 3 \mathrm{H} 2+\mathrm{H}$ & $0.100 \mathrm{E}+15$ & 0.000 & 0.000 & ! THORNE \\
\hline $\mathrm{CH}+\mathrm{CH} 2=\mathrm{C} 2 \mathrm{H} 2+\mathrm{H}$ & $0.400 \mathrm{E}+14$ & 0.000 & 0.000 & ! PG \\
\hline $\mathrm{CH}+\mathrm{CH}_{3}=\mathrm{C} 2 \mathrm{H} 3+\mathrm{H}$ & $0.300 \mathrm{E}+14$ & 0.000 & 0.000 & ! PG \\
\hline $\mathrm{CH}+\mathrm{CH} 4=\mathrm{C} 2 \mathrm{H} 4+\mathrm{H}$ & $0.600 \mathrm{E}+14$ & 0.000 & 0.000 & ! PG \\
\hline $\mathrm{C}+\mathrm{O} 2=\mathrm{CO}+\mathrm{O}$ & $0.200 \mathrm{E}+14$ & 0.000 & 0.000 & ! THORNE \\
\hline $\mathrm{C}+\mathrm{OH}=\mathrm{CO}+\mathrm{H}$ & $0.500 \mathrm{E}+14$ & 0.000 & 0.000 & ! THORNE \\
\hline $\mathrm{C}+\mathrm{CH} 3=\mathrm{C} 2 \mathrm{H} 2+\mathrm{H}$ & $0.500 \mathrm{E}+14$ & 0.000 & 0.000 & ! PG \\
\hline $\mathrm{C}+\mathrm{CH} 2=\mathrm{C} 2 \mathrm{H}+\mathrm{H}$ & $0.500 \mathrm{E}+14$ & 0.000 & 0.000 & ! PG \\
\hline $\mathrm{CH} 2+\mathrm{CO} 2=\mathrm{CH} 2 \mathrm{O}+\mathrm{CO}$ & $0.110 \mathrm{E}+12$ & 0.000 & 1000.000 & ! PG \\
\hline $\mathrm{CH} 2+\mathrm{O}=\mathrm{CO}+\mathrm{H}+\mathrm{H}$ & $0.500 \mathrm{E}+14$ & 0.000 & 0.000 & ! JAM 2/87 \\
\hline $\mathrm{CH} 2+\mathrm{O}=\mathrm{CO}+\mathrm{H} 2$ & $0.300 \mathrm{E}+14$ & 0.000 & 0.000 & ! JAM 2/87 \\
\hline $\mathrm{CH} 2+\mathrm{O}_{2}=\mathrm{CO} 2+\mathrm{H}+\mathrm{H}$ & $0.160 E+13$ & 0.000 & 1000.000 & \\
\hline $\mathrm{CH} 2+\mathrm{O} 2=\mathrm{CH} 2 \mathrm{O}+\mathrm{O}$ & $0.500 \mathrm{E}+14$ & 0.000 & 9000.000 & ! PG \\
\hline $\mathrm{CH}_{2}+\mathrm{O}_{2}=\mathrm{CO} 2+\mathrm{H}_{2}$ & $0.690 \mathrm{E}+12$ & 0.000 & 500.000 & ! PG \\
\hline $\mathrm{CH} 2+\mathrm{O} 2=\mathrm{CO}+\mathrm{H} 2 \mathrm{O}$ & $0.190 \mathrm{E}+11$ & 0.000 & -1000.000 & ! PG \\
\hline $\mathrm{CH} 2+\mathrm{O} 2=\mathrm{CO}+\mathrm{OH}+\mathrm{H}$ & $0.860 \mathrm{E}+11$ & 0.000 & -500.000 & ! PG \\
\hline $\mathrm{CH} 2+\mathrm{O} 2=\mathrm{HCO}+\mathrm{OH}$ & $0.430 \mathrm{E}+11$ & 0.000 & -500.000 & ! PG \\
\hline $\mathrm{CH} 2 \mathrm{O}+\mathrm{OH}=\mathrm{HCO}+\mathrm{H} 2 \mathrm{O}$ & $0.343 \mathrm{E}+10$ & 1.180 & -447.000 & ! NBS \\
\hline $\mathrm{CH} 2 \mathrm{O}+\mathrm{H}=\mathrm{HCO}+\mathrm{H} 2$ & $0.219 \mathrm{E}+09$ & 1.770 & 3000.000 & ! NBS \\
\hline $\mathrm{CH} 2 \mathrm{O}+\mathrm{M}=\mathrm{HCO}+\mathrm{H}+\mathrm{M}$ & $0.331 \mathrm{E}+17$ & 0.000 & 81000.000 & ! DEAN,C\$F 1980 \\
\hline $\mathrm{CH} 2 \mathrm{O}+\mathrm{O}=\mathrm{HCO}+\mathrm{OH}$ & $0.180 E+14$ & 0.000 & 3080.000 & ! NBS \\
\hline $\mathrm{HCO}+\mathrm{OH}=\mathrm{H} 2 \mathrm{O}+\mathrm{CO}$ & $0.100 \mathrm{E}+15$ & 0.000 & 0.000 & ! TEMPS \\
\hline $\mathrm{HCO}+\mathrm{M}=\mathrm{H}+\mathrm{CO}+\mathrm{M}$ & $0.250 \mathrm{E}+15$ & 0.000 & 16802.000 & ! WARNATZ,WAGBOW \\
\hline \multicolumn{5}{|c|}{$\mathrm{CO} / 1.87 / \mathrm{H} 2 / 1.87 / \mathrm{CH} 4 / 2.81 / \mathrm{CO} 2 / 3 . / \mathrm{H} 2 \mathrm{O} / 5 . /$} \\
\hline $\mathrm{HCO}+\mathrm{H}=\mathrm{CO}+\mathrm{H} 2$ & $0.119 \mathrm{E}+14$ & 0.250 & 0.000 & ! HARD.\$WAG. \\
\hline $\mathrm{HCO}+\mathrm{O}=\mathrm{CO}+\mathrm{OH}$ & $0.300 E+14$ & 0.000 & 0.000 & ! PG \\
\hline $\mathrm{HCO}+\mathrm{O}=\mathrm{CO} 2+\mathrm{H}$ & $0.300 E+14$ & 0.000 & 0.000 & ! PG \\
\hline $\mathrm{HCO}+\mathrm{O}_{2}=\mathrm{HO} 2+\mathrm{CO}$ & $0.330 E+14$ & -0.400 & 0.000 & ! VEYRET\$LESCLAUX \\
\hline $\mathrm{CO}+\mathrm{O}+\mathrm{M}=\mathrm{CO}+\mathrm{M}$ & $0.617 E+15$ & 0.000 & 3000.000 & ! NBS \\
\hline $\mathrm{CO}+\mathrm{OH}=\mathrm{CO}+\mathrm{H}$ & $0.151 \mathrm{E}+08$ & 1.300 & -758.000 & ! BAULCH\$DRYS \\
\hline $\mathrm{CO}+\mathrm{O}_{2}=\mathrm{CO} 2+\mathrm{O}$ & 2.53E 12 & 0.0 & 47688 & !TSANG,BAULCH \\
\hline
\end{tabular}




\begin{tabular}{|c|c|c|c|c|}
\hline $\mathrm{HO} 2+\mathrm{CO}=\mathrm{CO} 2+\mathrm{OH}$ & $0.580 \mathrm{E}+14$ & 0.000 & 22934.000 & ! ATRI ET AL, CSF \\
\hline $\mathrm{C} 2 \mathrm{H} 6+\mathrm{CH} 3=\mathrm{C} 2 \mathrm{H} 5+\mathrm{CH} 4$ & $0.550 \mathrm{E}+00$ & 4.000 & 8300.000 & \\
\hline $\mathrm{C} 2 \mathrm{H} 6+\mathrm{H}=\mathrm{C} 2 \mathrm{H} 5+\mathrm{H} 2$ & $0.540 \mathrm{E}+03$ & 3.500 & 5210.000 & ! CLARK\$DOVE \\
\hline $\mathrm{C} 2 \mathrm{H} 6+\mathrm{O}=\mathrm{C} 2 \mathrm{H} 5+\mathrm{OH}$ & $0.300 \mathrm{E}+08$ & 2.000 & 5115.000 & ! WARNATZ REVIEW \\
\hline $\mathrm{C} 2 \mathrm{H} 6+\mathrm{OH}=\mathrm{C} 2 \mathrm{H} 5+\mathrm{H} 2 \mathrm{O}$ & $0.870 \mathrm{E}+10$ & 1.050 & 1810.000 & ! PG \\
\hline $\mathrm{C} 2 \mathrm{H} 4+\mathrm{H}=\mathrm{C} 2 \mathrm{H} 3+\mathrm{H} 2$ & $0.110 \mathrm{E}+15$ & 0.000 & 8500.000 & ! WARNATZ? \\
\hline $\mathrm{C} 2 \mathrm{H} 4+\mathrm{O}=\mathrm{CH} 3+\mathrm{HCO}$ & $0.160 E+10$ & 1.200 & 746.000 & ! PG \\
\hline $\mathrm{C} 2 \mathrm{H} 4+\mathrm{OH}=\mathrm{C} 2 \mathrm{H} 3+\mathrm{H} 2 \mathrm{O}$ & $0.202 E+14$ & 0.000 & 5955.000 & ! TULLY 1987 \\
\hline $\mathrm{CH} 2+\mathrm{CH} 3=\mathrm{C} 2 \mathrm{H} 4+\mathrm{H}$ & $0.300 \mathrm{E}+14$ & 0.000 & 0.000 & ! JAM \\
\hline $\begin{array}{l}\mathrm{H}+\mathrm{C} 2 \mathrm{H} 4(+\mathrm{M})=\mathrm{C} 2 \mathrm{H} 5(+\mathrm{M}) \\
\mathrm{LOW} / 6.369 \mathrm{E} 27-2.76-54 . / \\
\mathrm{H} 2 / 2 / \mathrm{CO} / 2 / \mathrm{CO} 2 / 3 / \mathrm{H} 2 \mathrm{O} / 5 /\end{array}$ & $0.221 E+14$ & 0.000 & 2066.000 & \\
\hline $\mathrm{C} 2 \mathrm{H} 5+\mathrm{H}=\mathrm{CH} 3+\mathrm{CH} 3$ & $1.00 \mathrm{E}+14$ & 0.000 & 0.000 & \\
\hline $\mathrm{C} 2 \mathrm{H} 5+\mathrm{O} 2=\mathrm{C} 2 \mathrm{H} 4+\mathrm{HO} 2$ & $0.843 E+12$ & 0.000 & 3875.000 & ! NBS \\
\hline $\mathrm{C} 2 \mathrm{H} 2+\mathrm{O}=\mathrm{CH} 2+\mathrm{CO}$ & $0.102 E+08$ & 2.000 & 190 & ! JAM,FONT,PEETERS \\
\hline $\mathrm{C} 2 \mathrm{H} 2+\mathrm{O}=\mathrm{HCCO}+\mathrm{H}$ & $0.102 E+08$ & 2.000 & 1900.000 & ! JAM,FONT, ! \\
\hline $\mathrm{H} 2+\mathrm{C} 2 \mathrm{H}=\mathrm{C} 2 \mathrm{H} 2+\mathrm{H}$ & $0.409 \mathrm{E}+06$ & 2.390 & 864.300 & \\
\hline $\mathrm{H}+\mathrm{C} 2 \mathrm{H} 2(+\mathrm{M})=\mathrm{C} 2 \mathrm{H} 3(+\mathrm{M})$ & $0.554 \mathrm{E}+13$ & 0.000 & 2410.000 & \\
\hline $\begin{array}{l}\mathrm{LOW} / 2.67 \mathrm{E} 27-3.52410 . / \\
\mathrm{H} 2 / 2 / \mathrm{CO} / 2 / \mathrm{CO} 2 / 3 / \mathrm{H} 2 \mathrm{O} / 5 /\end{array}$ & & & & \\
\hline $\mathrm{C} 2 \mathrm{H} 3+\mathrm{H}=\mathrm{C} 2 \mathrm{H} 2+\mathrm{H} 2$ & $0.400 \mathrm{E}+14$ & 0.000 & 0.000 & ! HOYERMANN \\
\hline $\mathrm{C} 2 \mathrm{H} 3+\mathrm{O}=\mathrm{CH} 2 \mathrm{CO}+\mathrm{H}$ & $0.300 \mathrm{E}+14$ & 0.000 & 0.000 & ! HOYERMANN 21ST \\
\hline $\mathrm{C} 2 \mathrm{H} 3+\mathrm{O} 2=\mathrm{CH} 2 \mathrm{O}+\mathrm{HCO}$ & $0.400 \mathrm{E}+13$ & 0.000 & -250.000 & ! PG \\
\hline $\mathrm{C} 2 \mathrm{H} 3+\mathrm{OH}=\mathrm{C} 2 \mathrm{H} 2+\mathrm{H} 2 \mathrm{O}$ & $0.500 \mathrm{E}+13$ & 0.000 & 0.000 & ! JAM \\
\hline $\mathrm{C} 2 \mathrm{H} 3+\mathrm{CH} 2=\mathrm{C} 2 \mathrm{H} 2+\mathrm{CH} 3$ & $0.300 \mathrm{E}+14$ & 0.000 & 0.000 & ! MMSK \\
\hline $\mathrm{C}_{2} \mathrm{H}_{3}+\mathrm{C} 2 \mathrm{H}=\mathrm{C} 2 \mathrm{H}_{2}+\mathrm{C}_{2} \mathrm{H}_{2}$ & $0.300 E+14$ & 0.000 & 0.000 & ! MMSK \\
\hline $\mathrm{C} 2 \mathrm{H} 3+\mathrm{CH}=\mathrm{CH} 2+\mathrm{C} 2 \mathrm{H} 2$ & $0.500 \mathrm{E}+14$ & 0.000 & 0.000 & ! JAM \\
\hline $\mathrm{OH}+\mathrm{C} 2 \mathrm{H} 2=\mathrm{C} 2 \mathrm{H}+\mathrm{H} 2 \mathrm{O}$ & 3.37E7 & 2.0 & 14000 . & ! MLLER \\
\hline $\mathrm{OH}+\mathrm{C} 2 \mathrm{H} 2=\mathrm{HCCOH}+\mathrm{H}$ & $5.04 \mathrm{E} 5$ & 2.3 & 13500 . & ! MILLER \\
\hline $\mathrm{OH}+\mathrm{C} 2 \mathrm{H} 2=\mathrm{CH} 2 \mathrm{CO}+\mathrm{H}$ & $2.18 \mathrm{E}-4$ & 4.5 & -1000 & ! MILLER \\
\hline $\mathrm{OH}+\mathrm{C} 2 \mathrm{H} 2=\mathrm{CH} 3+\mathrm{CO}$ & 4.83E-4 & 4.0 & -2000 & ! MILLER \\
\hline $\mathrm{HCCOH}+\mathrm{H}=\mathrm{CH} 2 \mathrm{CO}+\mathrm{H}$ & $0.100 \mathrm{E}+14$ & 0.000 & 0.000 & ! JAM \\
\hline $\mathrm{C} 2 \mathrm{H} 2+\mathrm{O}=\mathrm{C} 2 \mathrm{H}+\mathrm{OH}$ & $0.316 \mathrm{E}+16$ & -0.600 & 15000.000 & \\
\hline $\mathrm{CH} 2 \mathrm{CO}+\mathrm{O}=\mathrm{CO} 2+\mathrm{CH} 2$ & $0.175 \mathrm{E}+13$ & 0.000 & 1350.000 & ! SEE \\
\hline $\mathrm{CH} 2 \mathrm{CO}+\mathrm{H}=\mathrm{CH} 3+\mathrm{CO}$ & $0.113 E+14$ & 0.000 & 3428.000 & ! MICHAEL \\
\hline $\mathrm{CH} 2 \mathrm{CO}+\mathrm{H}=\mathrm{HCCO}+\mathrm{H} 2$ & $0.500 \mathrm{E}+14$ & 0.000 & 8000.000 & ! MMSK \\
\hline $\mathrm{CH} 2 \mathrm{CO}+\mathrm{O}=\mathrm{HCCO}+\mathrm{OH}$ & $0.100 E+14$ & 0.000 & 8000.000 & ! MMSK \\
\hline $\mathrm{CH} 2 \mathrm{CO}+\mathrm{OH}=\mathrm{HCCO}+\mathrm{H} 2 \mathrm{O}$ & $0.750 E+13$ & 0.000 & 2000.000 & ! MMSK \\
\hline $\begin{array}{r}\mathrm{CH} 2 \mathrm{CO}(+\mathrm{M})=\mathrm{CH} 2+\mathrm{CO}(+\mathrm{M}) \\
\mathrm{LOW} / 3.6 \mathrm{E} 150.059270 .1\end{array}$ & $0.300 \mathrm{E}+15$ & 0.000 & 70980.000 & ! WAGNEF \\
\hline $\mathrm{C} 2 \mathrm{H}+\mathrm{O} 2=\mathrm{CO}+\mathrm{CO}+\mathrm{H}$ & $0.500 \mathrm{E}+14$ & 0.000 & 1500.000 & ! LANGESWAGNE! \\
\hline $\mathrm{C} 2 \mathrm{H}+\mathrm{C}_{2} \mathrm{H} 2=\mathrm{C} 4 \mathrm{H} 2+\mathrm{H}$ & $0.300 \mathrm{E}+14$ & 0.000 & 0.000 & ! MMSK \\
\hline $\mathrm{H}+\mathrm{HCCO}=\mathrm{CH} 2(\mathrm{~S})+\mathrm{CO}$ & $0.100 \mathrm{E}+15$ & 0.000 & 0.000 & ! PEETERS 1985 \\
\hline $\mathrm{O}+\mathrm{HCCO}=\mathrm{H}+\mathrm{CO}+\mathrm{CO}$ & $0.100 \mathrm{E}+15$ & 0.000 & 0.000 & ! PEETERS 1985 \\
\hline $\mathrm{HCCO}+\mathrm{O} 2=\mathrm{CO}+\mathrm{CO}+\mathrm{OH}$ & $0.160 \mathrm{E}+13$ & 0.000 & 854.000 & ! PEETERS \\
\hline $\mathrm{CH}+\mathrm{HCCO}=\mathrm{C} 2 \mathrm{H} 2+\mathrm{CO}$ & $0.500 \mathrm{E}+14$ & 0.000 & 0.000 & ! JAM EST \\
\hline $\mathrm{HCCO}+\mathrm{HCCO}=\mathrm{C} 2 \mathrm{H} 2+\mathrm{CO}+\mathrm{CO}$ & $0.100 \mathrm{E}+14$ & 0.000 & 0.000 & ! MMSK \\
\hline $\begin{array}{l}\mathrm{CH} 2(\mathrm{~S})+\mathrm{M}=\mathrm{CH} 2+\mathrm{M} \\
\mathrm{H} / 0.0 /\end{array}$ & $0.100 \mathrm{E}+14$ & 0.000 & 0.000 & ! NBS,ADJ \\
\hline $\mathrm{CH} 2(\mathrm{~S})+\mathrm{CH} 4=\mathrm{CH} 3+$ & 0.40 & 0.000 & 0.000 & \\
\hline $\mathrm{CH} 2(\mathrm{~S})+\mathrm{C} 2 \mathrm{H} 6=\mathrm{CH} 3+\mathrm{C} 2 \mathrm{H} 5$ & $0.120 \mathrm{E}+15$ & 0.000 & 0.000 & ! NBS \\
\hline
\end{tabular}




\begin{tabular}{|c|c|c|c|c|}
\hline $\mathrm{CH} 2(\mathrm{~S})+\mathrm{O} 2=\mathrm{CO}+\mathrm{OH}+\mathrm{H}$ & $0.300 \mathrm{E}+14$ & 0.000 & 0.000 & ! NBS \\
\hline $\mathrm{CH} 2(\mathrm{~S})+\mathrm{H} 2=\mathrm{CH} 3+\mathrm{H}$ & $0.700 \mathrm{E}+14$ & 0.000 & 0.000 & ! NBS \\
\hline $\mathrm{CH} 2(\mathrm{~S})+\mathrm{H}=\mathrm{CH}_{2}+\mathrm{H}$ & $0.200 \mathrm{E}+15$ & 0.000 & 0.000 & ! JAM \\
\hline $\mathrm{C} 2 \mathrm{H}+\mathrm{O}=\mathrm{CH}+\mathrm{CO}$ & $0.500 \mathrm{E}+14$ & 0.000 & 0.000 & ! BROWNE \\
\hline $\mathrm{C} 2 \mathrm{H}+\mathrm{OH}=\mathrm{HCCO}+\mathrm{H}$ & $0.200 \mathrm{E}+14$ & 0.000 & 0.000 & ! JAM,12/22 \\
\hline $\mathrm{CH} 2+\mathrm{CH} 2=\mathrm{C} 2 \mathrm{H} 2+\mathrm{H} 2$ & $0.400 \mathrm{E}+14$ & 0.000 & 0.000 & ! BRAUN,ET AL \\
\hline $\mathrm{CH} 2+\mathrm{HCCO}=\mathrm{C} 2 \mathrm{H} 3+\mathrm{CO}$ & $0.300 \mathrm{E}+14$ & 0.000 & 0.000 & ! JAM,1/11/82 \\
\hline $\mathrm{CH} 2+\mathrm{C} 2 \mathrm{H} 2=\mathrm{H} 2 \mathrm{CCCH}+\mathrm{H}$ & $0.120 \mathrm{E}+14$ & 0.000 & 6600.000 & ! BOHLAND ET \\
\hline $\mathrm{C} 4 \mathrm{H} 2+\mathrm{OH}=\mathrm{C} 3 \mathrm{H} 2+\mathrm{HCO}$ & $0.666 \mathrm{E}+13$ & 0.000 & -410.000 & ! PERRY \\
\hline $\mathrm{C} 3 \mathrm{H} 2+\mathrm{O} 2=\mathrm{HCO}+\mathrm{HCCO}$ & $0.100 \mathrm{E}+14$ & 0.000 & 0.000 & ! THORNE,ET AL \\
\hline $\mathrm{H} 2 \mathrm{CCCH}+\mathrm{O} 2=\mathrm{CH} 2 \mathrm{CO}+\mathrm{HCO}$ & $0.300 \mathrm{E}+11$ & 0.000 & 2868.000 & ! GUTMAN,21ST \\
\hline $\mathrm{H} 2 \mathrm{CCCH}+\mathrm{O}=\mathrm{CH} 2 \mathrm{O}+\mathrm{C} 2 \mathrm{H}$ & $0.200 \mathrm{E}+14$ & 0.000 & 0.000 & ! JAM \\
\hline $\mathrm{H} 2 \mathrm{CCCH}+\mathrm{OH}=\mathrm{C} 3 \mathrm{H} 2+\mathrm{H} 2 \mathrm{O}$ & $0.200 \mathrm{E}+14$ & 0.000 & 0.000 & ! JAM \\
\hline $\mathrm{C} 2 \mathrm{H} 2+\mathrm{C} 2 \mathrm{H} 2=\mathrm{H} 2 \mathrm{CCCCH}+\mathrm{H}$ & $0.200 \mathrm{E}+13$ & 0.000 & 45900.000 & ! MMSK \\
\hline $\mathrm{H} 2 \mathrm{CCCCH}+\mathrm{M}=\mathrm{C} 4 \mathrm{H} 2+\mathrm{H}+\mathrm{M}$ & $0.100 \mathrm{E}+17$ & 0.000 & 59700.000 & ! MMSK \\
\hline $\mathrm{CH} 2(\mathrm{~S})+\mathrm{C} 2 \mathrm{H} 2=\mathrm{H} 2 \mathrm{CCCH}+\mathrm{H}$ & $0.300 \mathrm{E}+14$ & 0.000 & 0.000 & ! EST \\
\hline $\mathrm{C} 4 \mathrm{H} 2+\mathrm{O}=\mathrm{C} 3 \mathrm{H} 2+\mathrm{CO}$ & $0.120 \mathrm{E}+13$ & 0.000 & 0.000 & ! MMSK \\
\hline $\mathrm{C} 2 \mathrm{H} 2+\mathrm{O} 2=\mathrm{HCCO}+\mathrm{OH}$ & $0.200 \mathrm{E}+09$ & 1.500 & 30100.000 & ! MMSK \\
\hline $\mathrm{C} 2 \mathrm{H} 2+\mathrm{M}=\mathrm{C} 2 \mathrm{H}+\mathrm{H}+\mathrm{M}$ & $0.420 \mathrm{E}+17$ & 0.000 & 107000.000 & ! MMSK \\
\hline $\mathrm{C} 2 \mathrm{H} 4+\mathrm{M}=\mathrm{C} 2 \mathrm{H} 2+\mathrm{H} 2+\mathrm{M}$ & $0.150 \mathrm{E}+16$ & 0.000 & 55800.000 & ! KIEFER \\
\hline $\mathrm{C} 2 \mathrm{H} 4+\mathrm{M}=\mathrm{C} 2 \mathrm{H} 3+\mathrm{H}+\mathrm{M}$ & $0.140 \mathrm{E}+17$ & 0.000 & 82360.000 & ! KIEFER \\
\hline $\mathrm{H} 2+\mathrm{O} 2=2 \mathrm{OH}$ & $0.170 \mathrm{E}+14$ & 0.000 & 47780.000 & \\
\hline $\mathrm{OH}+\mathrm{H} 2=\mathrm{H} 2 \mathrm{O}+\mathrm{H}$ & $0.117 \mathrm{E}+10$ & 1.300 & 3626.000 & ! D-LSW \\
\hline $\mathrm{O}+\mathrm{OH}=\mathrm{O} 2+\mathrm{H}$ & $0.400 \mathrm{E}+15$ & -0.500 & 0.000 & ! JAM 1986 \\
\hline $\mathrm{O}+\mathrm{H} 2=\mathrm{OH}+\mathrm{H}$ & $0.506 \mathrm{E}+05$ & 2.670 & 6290.000 & ! KLEMM,ET AL 1986 \\
\hline $\mathrm{H}+\mathrm{O} 2+\mathrm{M}=\mathrm{HO} 2+\mathrm{M}$ & $0.361 E+18$ & -0.720 & 0.000 & ! DIXON-LEWIS \\
\hline \multicolumn{5}{|c|}{$\mathrm{H} 2 \mathrm{O} / 18.6 / \mathrm{CO} 2 / 4.2 / \mathrm{H} 2 / 2.86 / \mathrm{CO} / 2.11 / \mathrm{N} 2 / 1.26 /$} \\
\hline $\mathrm{OH}+\mathrm{HO} 2=\mathrm{H} 2 \mathrm{O}+\mathrm{O} 2$ & $0.750 \mathrm{E}+13$ & 0.000 & 0.000 & ! D-L \\
\hline $\mathrm{H}+\mathrm{HO}_{2}=2 \mathrm{OH}$ & $0.140 \mathrm{E}+15$ & 0.000 & 1073.000 & ! D-L \\
\hline $\mathrm{O}+\mathrm{HO} 2=\mathrm{O} 2+\mathrm{OH}$ & $0.140 \mathrm{E}+14$ & 0.000 & 1073.000 & ! D-L \\
\hline $2 \mathrm{OH}=\mathrm{O}+\mathrm{H} 2 \mathrm{O}$ & $0.600 \mathrm{E}+09$ & 1.300 & 0.000 & ! COHEN-WEST. \\
\hline $\mathrm{H}+\mathrm{H}+\mathrm{M}=\mathrm{H} 2+\mathrm{M}$ & $0.100 \mathrm{E}+19$ & -1.000 & 0.000 & ! D-L \\
\hline \multicolumn{5}{|l|}{$\mathrm{H} 2 / 0.0 / \mathrm{H} 2 \mathrm{O} / 0.0 / \mathrm{CO} 2 / 0.0 /$} \\
\hline $\mathrm{H}+\mathrm{H}+\mathrm{H} 2=\mathrm{H} 2+\mathrm{H} 2$ & $0.920 \mathrm{E}+17$ & -0.600 & 0.000 & \\
\hline $\mathrm{H}+\mathrm{H}+\mathrm{H} 2 \mathrm{O}=\mathrm{H} 2+\mathrm{H} 2 \mathrm{O}$ & $0.600 \mathrm{E}+20$ & -1.250 & 0.000 & \\
\hline $\mathrm{H}+\mathrm{H}+\mathrm{CO} 2=\mathrm{H} 2+\mathrm{CO} 2$ & $0.549 \mathrm{E}+21$ & -2.000 & 0.000 & ! D-L \\
\hline \multicolumn{5}{|l|}{$\mathrm{H} 2 \mathrm{O} / 5 /$} \\
\hline $\begin{array}{c}\mathrm{H}+\mathrm{O}+\mathrm{M}=\mathrm{OH}+\mathrm{M} \\
\mathrm{H} 2 \mathrm{O} / 5 /\end{array}$ & \multicolumn{3}{|c|}{$\mathrm{H} 2 \mathrm{O} / 5 /$} & ! D-L \\
\hline $\mathrm{O}+\mathrm{O}+\mathrm{M}=\mathrm{O} 2+\mathrm{M}$ & $0.189 \mathrm{E}+14$ & 0.000 & -1788.000 & ! NBS \\
\hline $\mathrm{H}+\mathrm{HO} 2=\mathrm{H} 2+\mathrm{O}_{2}$ & $0.125 E+14$ & 0.000 & 0.000 & ! D-L \\
\hline $\mathrm{HO}_{2}+\mathrm{HO}_{2}=\mathrm{H}_{2} \mathrm{O} 2+\mathrm{O} 2$ & $0.200 \mathrm{E}+13$ & 0.000 & 0.000 & \\
\hline $\mathrm{H} 2 \mathrm{O} 2+\mathrm{M}=\mathrm{OH}+\mathrm{OH}+\mathrm{M}$ & $0.130 \mathrm{E}+18$ & 0.000 & 45500.000 & \\
\hline $\mathrm{H} 2 \mathrm{O} 2+\mathrm{H}=\mathrm{HO} 2+\mathrm{H}_{2}$ & $0.160 \mathrm{E}+13$ & 0.000 & 3800.000 & \\
\hline $\mathrm{H} 2 \mathrm{O}_{2}+\mathrm{OH}=\mathrm{H} 2 \mathrm{O}+\mathrm{HO}_{2}$ & $0.100 \mathrm{E}+14$ & 0.000 & 1800.000 & \\
\hline $\mathrm{CH}+\mathrm{N} 2=\mathrm{HCN}+\mathrm{N}$ & $0.300 \mathrm{E}+12$ & 0.000 & 13600.000 & ! PG,JAM \\
\hline $\mathrm{CN}+\mathrm{N}=\mathrm{C}+\mathrm{N} 2$ & $0.104 \mathrm{E}+16$ & -0.500 & 0.000 & ! PHILLIPS,ROTH? \\
\hline $\mathrm{CH} 2+\mathrm{N} 2=\mathrm{HCN}+\mathrm{NH}$ & $0.100 E+14$ & 0.000 & 74000.000 & ! PG \\
\hline $\mathrm{H} 2 \mathrm{CN}+\mathrm{N}=\mathrm{N} 2+\mathrm{CH} 2$ & $0.200 \mathrm{E}+14$ & 0.000 & 0.000 & ! JAM \\
\hline $\mathrm{H} 2 \mathrm{CN}+\mathrm{M}=\mathrm{HCN}+\mathrm{H}+\mathrm{M}$ & $0.300 \mathrm{E}+15$ & 0.000 & 22000.000 & ! JAM \\
\hline $\mathrm{C}+\mathrm{NO}=\mathrm{CN}+\mathrm{O}$ & $0.660 \mathrm{E}+14$ & 0.000 & 0.000 & ! JAM \\
\hline
\end{tabular}




\author{
$\mathrm{CH}+\mathrm{NO}=\mathrm{HCN}+\mathrm{O}$ \\ $\mathrm{CH} 2+\mathrm{NO}=\mathrm{HCNO}+\mathrm{H}$ \\ $\mathrm{CH} 3+\mathrm{NO}=\mathrm{HCN}+\mathrm{H} 2 \mathrm{O}$ \\ $\mathrm{CH} 3+\mathrm{NO}=\mathrm{H} 2 \mathrm{CN}+\mathrm{OH}$ \\ $\mathrm{HCCO}+\mathrm{NO}=\mathrm{HCNO}+\mathrm{CO}$ \\ $\mathrm{CH} 2(\mathrm{~S})+\mathrm{NO}=\mathrm{HCN}+\mathrm{OH}$ \\ $\mathrm{HCNO}+\mathrm{H}=\mathrm{HCN}+\mathrm{OH}$ \\ $\mathrm{CH} 2+\mathrm{N}=\mathrm{HCN}+\mathrm{H}$ \\ $\mathrm{CH}+\mathrm{N}=\mathrm{CN}+\mathrm{H}$ \\ $\mathrm{CO} 2+\mathrm{N}=\mathrm{NO}+\mathrm{CO}$ \\ $\mathrm{HCCO}+\mathrm{N}=\mathrm{HCN}+\mathrm{CO}$ \\ $\mathrm{CH} 3+\mathrm{N}=\mathrm{H} 2 \mathrm{CN}+\mathrm{H}$ \\ $\mathrm{C} 2 \mathrm{H} 3+\mathrm{N}=\mathrm{HCN}+\mathrm{CH} 2$ \\ $\mathrm{H} 2 \mathrm{CCCH}+\mathrm{N}=\mathrm{HCN}+\mathrm{C} 2 \mathrm{H} 2$ \\ $\mathrm{HCN}+\mathrm{OH}=\mathrm{CN}+\mathrm{H} 2 \mathrm{O}$ \\ $\mathrm{OH}+\mathrm{HCN}=\mathrm{HOCN}+\mathrm{H}$ \\ $\mathrm{OH}+\mathrm{HCN}=\mathrm{HNCO}+\mathrm{H}$ \\ $\mathrm{OH}+\mathrm{HCN}=\mathrm{NH} 2+\mathrm{CO}$ \\ $\mathrm{HOCN}+\mathrm{H}=\mathrm{HNCO}+\mathrm{H}$ \\ $\mathrm{HCN}+\mathrm{O}=\mathrm{NCO}+\mathrm{H}$ \\ $\mathrm{HCN}+\mathrm{O}=\mathrm{NH}+\mathrm{CO}$ \\ $\mathrm{HCN}+\mathrm{O}=\mathrm{CN}+\mathrm{OH}$ \\ $\mathrm{CN}+\mathrm{H} 2=\mathrm{HCN}+\mathrm{H}$ \\ $\mathrm{CN}+\mathrm{O}=\mathrm{CO}+\mathrm{N}$ \\ $\mathrm{CN}+\mathrm{O} 2=\mathrm{NCO}+\mathrm{O}$ \\ $\mathrm{CN}+\mathrm{OH}=\mathrm{NCO}+\mathrm{H}$ \\ $\mathrm{CN}+\mathrm{HCN}=\mathrm{C} 2 \mathrm{~N} 2+\mathrm{H}$ \\ $\mathrm{CN}+\mathrm{NO} 2=\mathrm{NCO}+\mathrm{NO}$ \\ $\mathrm{CN}+\mathrm{N} 2 \mathrm{O}=\mathrm{NCO}+\mathrm{N} 2$ \\ $\mathrm{C} 2 \mathrm{~N} 2+\mathrm{O}=\mathrm{NCO}+\mathrm{CN}$ \\ $\mathrm{C} 2 \mathrm{~N} 2+\mathrm{OH}=\mathrm{HOCN}+\mathrm{CN}$ \\ $\mathrm{HO} 2+\mathrm{NO}=\mathrm{NO} 2+\mathrm{OH}$ \\ $\mathrm{NO} 2+\mathrm{H}=\mathrm{NO}+\mathrm{OH}$ \\ $\mathrm{NO} 2+\mathrm{O}=\mathrm{NO}+\mathrm{O} 2$ \\ $\mathrm{NO} 2+\mathrm{M}=\mathrm{NO}+\mathrm{O}+\mathrm{M}$ \\ $\mathrm{NCO}+\mathrm{H}=\mathrm{NH}+\mathrm{CO}$ \\ $\mathrm{NCO}+\mathrm{O}=\mathrm{NO}+\mathrm{CO}$ \\ $\mathrm{NCO}+\mathrm{N}=\mathrm{N} 2+\mathrm{CO}$ \\ $\mathrm{NCO}+\mathrm{OH}=\mathrm{NO}+\mathrm{HCO}$ \\ $\mathrm{NCO}+\mathrm{M}=\mathrm{N}+\mathrm{CO}+\mathrm{M}$ \\ $\mathrm{NCO}+\mathrm{NO}=\mathrm{N} 2 \mathrm{O}+\mathrm{CO}$ \\ $\mathrm{NCO}+\mathrm{H} 2=\mathrm{HNCO}+\mathrm{H}$ \\ $\mathrm{HNCO}+\mathrm{H}=\mathrm{NH} 2+\mathrm{CO}$ \\ $\mathrm{HNCO}+\mathrm{M}=\mathrm{NH}+\mathrm{CO}$ \\ $\mathrm{HNCO}+\mathrm{NH}=\mathrm{NH} 2+\mathrm{NCO}$ \\ $\mathrm{HNCO}+\mathrm{NH} 2=\mathrm{NH} 3+\mathrm{NCO}$ \\ $\mathrm{OH}+\mathrm{HNCO}=\mathrm{NCO}+\mathrm{H} 2 \mathrm{O}$ \\ $\mathrm{HNCO}+\mathrm{O}=\mathrm{HNO}+\mathrm{CO}$ \\ $\mathrm{NH}+\mathrm{O} 2=\mathrm{HNO}+\mathrm{O}$ \\ $\mathrm{NH}+\mathrm{O} 2=\mathrm{NO}+\mathrm{OH}$ \\ $\mathrm{NH}+\mathrm{NO}=\mathrm{N} 2 \mathrm{O}+\mathrm{H}$ \\ $\mathrm{N} 2 \mathrm{O}+\mathrm{OH}=\mathrm{N} 2+\mathrm{HO} 2$
}

\begin{tabular}{|c|c|c|c|}
\hline $.110 \mathrm{E}+15$ & 0.000 & 0.000 & ! BERMAN 82 \\
\hline $0.139 E+13$ & 0.000 & -1100.000 & ! VINCK\$DEB \\
\hline $100 \mathrm{E}+12$ & 0.000 & 15000.000 & ! JAM \\
\hline $100 \mathrm{E}+12$ & 0.000 & 15000.000 & ! JAM \\
\hline $200 E+14$ & 0.000 & 0.000 & ! JAM \\
\hline $200 \mathrm{E}+14$ & 0.000 & 0.000 & ! JAM \\
\hline $100 E+15$ & 0.000 & 12000.000 & ! PG \\
\hline $500 E+14$ & 0.000 & 0.000 & ! JAM \\
\hline $130 E+14$ & 0.000 & 0.000 & ! JAM \\
\hline $190 \mathrm{E}+12$ & 0.000 & 3400.000 & ! CRC \\
\hline $500 E+14$ & 0.000 & 0.000 & ! JAM \\
\hline $300 E+14$ & 0.000 & 0.000 & ! JAM \\
\hline $200 E+14$ & 0.000 & 0.000 & ! JAM \\
\hline $100 \mathrm{E}+14$ & 0.000 & 0.000 & ! JAM \\
\hline $145 E+14$ & 0.000 & 10929.000 & ! SZEKELY \\
\hline $585 E+05$ & 2.400 & 12500.000 & ! MILLER\$MEL \\
\hline $.198 \mathrm{E}-02$ & 4.000 & 1000.000 & ! MILLER\$MEL \\
\hline $783 \mathrm{E}-03$ & 4.000 & 4000.000 & ! MILLER\$MEL \\
\hline $100 E+14$ & 0.000 & 0.000 & ! JAM \\
\hline $138 \mathrm{E}+05$ & 2.640 & 4980.000 & ! PERRY \\
\hline $345 E+04$ & 2.640 & 4980.000 & ! PERRY \\
\hline $270 \mathrm{E}+10$ & 1.580 & 29200.000 & ! MILLER \\
\hline $.295 E+06$ & 2.450 & 2237.000 & ! WAGNER\$BAIR \\
\hline $0.180 E+14$ & 0.000 & 0.000 & ! LOUGE\&HANSON \\
\hline $0.560 E+13$ & 0.000 & 0.000 & ! LOUGE\$HANSON \\
\hline $0.600 E+14$ & 0.000 & 0.000 & ! HAYNES \\
\hline $0.200 \mathrm{E}+14$ & 0.000 & 0.000 & ! STANFORD \\
\hline $0.300 \mathrm{E}+14$ & 0.000 & 0.000 & ! JAM \\
\hline $0.100 E+14$ & 0.000 & 0.000 & ! JAM \\
\hline $0.457 \mathrm{E}+13$ & 0.000 & 8880.000 & ! STANFORD \\
\hline $0.186 E+12$ & 0.000 & 2900.000 & ! PHILLIPS \\
\hline $0.211 \mathrm{E}+13$ & 0.000 & -479.000 & ! HOWARD \\
\hline $0.350 \mathrm{E}+15$ & 0.000 & 1500.000 & \\
\hline $0.100 \mathrm{E}+14$ & 0.000 & 600.000 & \\
\hline $0.110 \mathrm{E}+17$ & 0.000 & 66000.000 & ! PG \\
\hline $0.500 \mathrm{E}+14$ & 0.000 & 0.000 & ! JAM \\
\hline $0.200 E+14$ & 0.000 & 0.000 & ! JAM \\
\hline $0.200 E+14$ & 0.000 & 0.000 & ! JAM,LIF\$FRENK \\
\hline $1.0 \mathrm{E} 12$ & 0.0 & 20000 . & !JAM \\
\hline $0.310 \mathrm{E}+17$ & -0.500 & 48000.000 & ! LOUGE\$HANSON \\
\hline $0.100 \mathrm{E}+14$ & 0.000 & -390.000 & ! PERRY \\
\hline $0.858 E+13$ & 0.000 & 9000.000 & ! PERRY,LOUGE \\
\hline $9.39 \mathrm{E} 4$ & 2.5 & 8000 . & !MERTENS,JAM \\
\hline $1.14 \mathrm{E} 16$ & 0.0 & 86000 . & !M\&B WSS \\
\hline $3.0 \mathrm{E} 13$ & 0.0 & 23700 . & !M\&B WSS \\
\hline $5.0 \mathrm{E} 12$ & 0.0 & 6200. & !M\&B WSS \\
\hline $2.65 \mathrm{E} 12$ & 0.0 & 5540. & !M\&B WSS \\
\hline $3.25 \mathrm{E} 12$ & 0.0 & 10300. & !M\&B WSS \\
\hline $0.100 E+14$ & 0.000 & 12000.000 & ! NH3 CST \\
\hline $0.760 \mathrm{E}+11$ & 0.000 & 1530.000 & ! HACK.ET AL \\
\hline $.240 E+16$ & -0.800 & 0.000 & ! JAM,9/87 \\
\hline $0.200 E+13$ & 0.000 & 10000.000 & ! JAM,9/87 \\
\hline
\end{tabular}




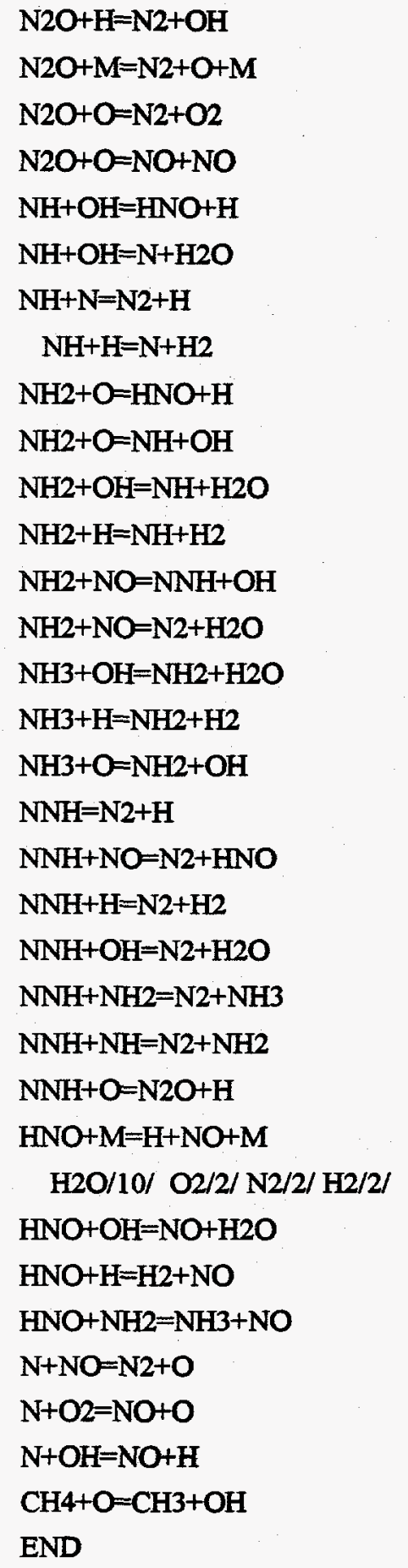

$$
\begin{array}{llll}
0.760 \mathrm{E}+14 & 0.000 & 15200.000 & \text { ! NH3 CST } \\
0.160 \mathrm{E}+15 & 0.000 & 51600.000 & \text { ! PG } \\
0.100 \mathrm{E}+15 & 0.000 & 28200.000 & \text { ! PG } \\
0.100 \mathrm{E}+15 & 0.000 & 28200.000 & \text { ! PG } \\
0.200 \mathrm{E}+14 & 0.000 & 0.000 & \text { ! NH3 CST } \\
0.500 \mathrm{E}+12 & 0.500 & 2000.000 & \text { ! NH3 CST } \\
0.300 \mathrm{E}+14 & 0.000 & 0.000 & \text { ! JAM } \\
0.100 \mathrm{E}+15 & 0.000 & 0.000 & \text { ! JAM } \\
0.663 \mathrm{E}+15 & -0.500 & 0.000 & \\
0.675 \mathrm{E}+13 & 0.000 & 0.000 & \\
0.400 \mathrm{E}+07 & 2.000 & 1000.000 & \text { ! JAM,9/87 } \\
0.692 \mathrm{E}+14 & 0.000 & 3650.000 & \\
0.640 \mathrm{E}+16 & -1.250 & 0.000 & \\
0.620 \mathrm{E}+16 & -1.250 & 0.000 & \\
0.204 \mathrm{E}+07 & 2.040 & 566.000 & \text { ! LOUGE } \\
0.636 \mathrm{E}+06 & 2.390 & 10171.000 & \text { ! MICHAEL } \\
0.210 \mathrm{E}+14 & 0.000 & 9000.000 & \text { ! PG } \\
0.100 \mathrm{E}+05 & 0.000 & 0.000 & \text { ! JAM,9/87 } \\
0.500 \mathrm{E}+14 & 0.000 & 0.000 & \\
0.100 \mathrm{E}+15 & 0.000 & 0.000 & \text { ! JAM,9/87 } \\
0.500 \mathrm{E}+14 & 0.000 & 0.000 & \\
0.500 \mathrm{E}+14 & 0.000 & 0.000 & \text { ? } \\
0.500 \mathrm{E}+14 & 0.000 & 0.000 & \\
0.100 \mathrm{E}+15 & 0.000 & 0.000 & \\
0.150 \mathrm{E}+17 & 0.000 & 48680.000 & \text { ! NH3 CST }
\end{array}
$$$$
\begin{array}{llll}
0.360 \mathrm{E}+14 & 0.000 & 0.000 & ! \mathrm{NH} 3 \mathrm{CST}
\end{array}
$$$$
\begin{array}{llll}
0.500 \mathrm{E}+13 & 0.000 & 0.000 & ! \mathrm{NH} 3 \mathrm{CST}
\end{array}
$$$$
\begin{array}{llll}
0.200 \mathrm{E}+14 & 0.000 & 1000.000 & ! \mathrm{NH} 3 \mathrm{CST}
\end{array}
$$$$
\begin{array}{llll}
0.327 \mathrm{E}+13 & 0.300 & 0.000 & \text { ! LEEDS,MONAT }
\end{array}
$$$$
0.640 \mathrm{E}+10 \quad 1.000 \quad 6280.000
$$$$
\begin{array}{llll}
0.380 E+14 & 0.000 & 0.000 & \text { ! SMTH,FLOWER }
\end{array}
$$$$
\begin{array}{llll}
1.02 E 9 & 1.5 & 8604 . & \text { !TSANG }
\end{array}
$$ 


\section{Appendix B}

\section{TEMPERATURE CORRECTIONS}

The temperature corrections applied to thermocouple measurements follow the procedure outlined by Bradley and Matthews [31]. A number of simplifying assumptions are invoked, including: (1) negligible conduction losses, (2) steady-state heat transfer, (3) negligible radiant energy exchange between the wire and surrounding gases, and (4) negligible heat release by chemical reaction at the surface of the thermocouple.

With the above assumptions, an overall energy balance on the thermocouple bead yields:

$$
\mathrm{h}\left(\mathrm{T}_{\mathrm{g}}-\mathrm{T}_{\mathrm{b}}\right)=\varepsilon \sigma\left(\mathrm{T}_{\mathrm{b}}^{4}-\mathrm{T}_{\infty}^{4}\right)
$$

where $T_{g}, T_{b}$, and $T_{\infty}$ are the gas, bead, and ambient temperature, respectively; $h$ is the convective heat transfer coefficient; $\varepsilon$ is the emissivity of the coated bead; and $\sigma$ is the Stefan-Boltzmann constant. Solving Eqn. B.1 for the gas temperature yields:

$$
\mathrm{T}_{\mathrm{g}}=\mathrm{T}_{\mathrm{b}}+\frac{\varepsilon \sigma}{\mathrm{h}}\left(\mathrm{T}_{\mathrm{b}}^{4}-\mathrm{T}_{\infty}^{4}\right)
$$

The bead emissivity used throughout this work was $\varepsilon=0.25$, which is based on acceptable values of $\mathrm{Al}_{2} \mathrm{O}_{3}$ as given by Modest [32]. Also, this emissivity always resulted in corrected temperatures less than the adiabatic flame temperature. The heat transfer coefficient, $h$, was calculated based on a Nusselt number expression of Eckert and Drake [33] for a cylindrical bead. 


$$
\mathrm{Nu}_{\mathrm{d}}=\frac{h \mathrm{~h}}{\mathrm{k}}=0.989 \mathrm{Re}^{0.33} \operatorname{Pr}^{0.333}
$$

Nitrogen was used to approximate gas properties within the flame for calculating the thermal conductivity (k), the Reynolds number ( $R e)$, and the Prandtl number (Pr). The properties of $\mathrm{N}_{2}$ were calculated at the mean gas temperature defined as,

$$
T_{m}=\frac{T_{g}+T_{b}}{2} .
$$

The velocities in these flames needed to calculate the Reynolds number were based on measured values from similar $\mathrm{CH}_{4}$-air jet diffusion flame experiments by Richardson [28]. 


\section{Appendix C}

\section{NOx AND CO EMISSION INDICES}

Defining the carbon monoxide emission index as

$$
\mathrm{EI}_{\mathrm{CO}} \equiv \frac{\dot{\mathbf{m}}_{\text {tot }}}{\dot{\mathbf{m}}_{\mathrm{CH} 4}} \mathbf{Y}_{\mathrm{CO}}
$$

we can determine the mass fraction of carbon monoxide in the exhaust gas stream, $\mathrm{Y}_{\mathrm{co}}$, by applying conservation of species and mass principles. The total flowrate appearing in the numerator of Eqn. C. 1 is known:

$$
\dot{\mathbf{m}}_{\mathrm{tot}}=\dot{\mathrm{m}}_{\mathrm{air}}+\dot{\mathbf{m}}_{\mathrm{CH} 4}+\dot{\mathbf{m}}_{\mathrm{dil}}
$$

Applying an overall mass balance on the $\mathrm{C}$ atom yields,

$$
\dot{\mathbf{m}}_{\mathrm{CH} 4} \mathbf{Y}_{\mathrm{C}, \mathrm{CH} 4}+\dot{\mathbf{m}}_{\mathrm{sir}} \mathbf{Y}_{\mathrm{CO}_{2}, \infty} \frac{\mathbf{M W}_{\mathrm{C}}}{\mathbf{M W}_{\mathrm{CO} 2}}=\dot{\mathbf{m}}_{\mathrm{tot}} \mathbf{Y}_{\mathrm{CO} 2} \frac{\mathbf{M W}_{\mathrm{C}}}{\mathbf{M W}_{\mathrm{CO} 2}}+\dot{\mathbf{m}}_{\mathrm{tot}} \mathbf{Y}_{\mathrm{CO}} \frac{\mathbf{M W}_{\mathrm{C}}}{\mathbf{M W} \mathbf{W O}_{\mathrm{CO}}}
$$

which introduces the additional unknown of the mass fraction of carbon dioxide in the

exhaust stream, $Y_{\mathrm{CO}_{2}}$. The ambient carbon dioxide mass fraction, $\mathrm{Y}_{\mathrm{CO}_{2} \infty}$, is known, and the mass fraction of carbon in the fuel can be expressed in terms of known quantities as

$$
\mathbf{Y}_{\mathrm{c}, \mathrm{CH} 4}=\frac{\mathrm{MW}_{\mathrm{C}}}{\mathbf{M W}_{\mathrm{CH}_{4}}}
$$

Now, we can express the two unknowns, $Y_{\mathrm{co}}$ and $\mathrm{Y}_{\mathrm{CO}_{2}}$, on a dry basis as

$$
Y_{\mathrm{CO}}=X_{\mathrm{co}}\left(1-\mathbf{X}_{\mathrm{H} 2 \mathrm{O}}\right) \frac{\mathrm{MW}_{\mathrm{CO}}}{\mathrm{MW}_{\text {wet mix }}}
$$

and, 


$$
Y_{\mathrm{CO}_{2}}=\mathrm{X}_{\mathrm{CO}_{2}}\left(1-\mathrm{X}_{\mathrm{H} 2 \mathrm{O}}\right) \frac{\mathrm{MW}_{\mathrm{CO} 2}}{\mathrm{MW}_{\text {wet mix }}}
$$

Equations C.5 and C.6 now contain two additional unknowns, the mole fraction of water in the exhaust stream, $\mathrm{X}_{\mathrm{H} 2 \mathrm{O}}$, and the molecular weight of the wet mixture, $\mathrm{MW}_{\text {wet mix. }}$ The mole fraction of water in the exhaust stream can be calculated assuming that all of hydrogen in the fuel is converted to water:

$$
\mathbf{Y}_{\mathrm{H}_{2}}=\mathbf{Y}_{\mathrm{H}_{2} \mathrm{O}} \frac{\mathbf{M W}_{\mathrm{H}_{2}}}{\mathbf{M W}_{\mathrm{H}_{2} \mathrm{O}}}
$$

solving for the mass fraction of water yields,

$$
\mathbf{Y}_{\mathrm{H} 2 \mathrm{O}}=\mathbf{Y}_{\mathrm{H}_{2}} \frac{\mathrm{MW}_{\mathrm{H} 2 \mathrm{O}}}{\mathbf{M W _ { \mathrm { H } 2 }}}
$$

Now, an overall hydrogen mass balance gives

$$
\dot{\mathbf{m}}_{\mathrm{tot}} \mathbf{Y}_{\mathrm{H}_{2}}=\dot{\mathbf{m}}_{\mathrm{CH}_{4}} \mathbf{Y}_{\mathrm{H}_{2} \mathrm{CH}_{4}} \text {, }
$$

solving for the hydrogen mass fraction,

$$
\mathbf{Y}_{\mathrm{H}_{2}}=\frac{\dot{\mathrm{m}}_{\mathrm{CH} 4}}{\dot{\mathrm{m}}_{\mathrm{tot}}} \mathbf{Y}_{\mathrm{H} 2, \mathrm{CH} 4}
$$

The mass fraction of hydrogen in the fuel in Eqn. C.10 can be written as

$$
\mathrm{Y}_{\mathrm{H}_{2}, \mathrm{CH}_{4}}=2 \frac{\mathrm{MW}_{\mathrm{H}_{2}}}{\mathrm{MW}_{\mathrm{CH}_{4}}}
$$

Finally, substituting Eqns. C.10 and C.11 into C.8 yields,

$$
\mathbf{Y}_{\mathrm{H}_{2} \mathrm{O}}=2 \frac{\dot{\mathrm{m}}_{\mathrm{CH}_{4}}}{\dot{\mathrm{m}}_{\mathrm{tot}}} \frac{\mathbf{M W}_{\mathrm{H} 20}}{\mathbf{M W}_{\mathrm{CH}_{4}}}
$$

Now, converting this known mass fraction of water in the exhaust stream to a mole fraction gives, 


$$
\mathbf{X}_{\mathrm{H} 2 \mathrm{O}}=2 \frac{\dot{\mathrm{m}}_{\mathrm{CH}}}{\dot{\mathrm{m}}_{\text {tot }}} \frac{\mathbf{M W}_{\text {wot mix }}}{\mathbf{M W}_{\mathrm{CH} 4}}
$$

Substituting Eqn. C.13 into equations C.5 and C. 6 for the $\mathrm{CO}$ and $\mathrm{CO}_{2}$ mass fractions respectively yields

$$
\mathbf{Y}_{\mathrm{Co}}=\mathbf{X}_{\mathrm{Co}} \frac{\mathbf{M W}_{\mathrm{CO}}}{\mathbf{M W}_{\text {wet mix }}}\left(1-2 \frac{\dot{\mathbf{m}}_{\mathrm{CH}_{4}}}{\dot{\mathrm{m}}_{\mathrm{tot}}} \frac{\mathrm{MW}_{\text {wet mix }}}{\mathrm{MW}_{\mathrm{CH}_{4}}}\right)
$$

and,

$$
\mathrm{Y}_{\mathrm{CO}_{2}}=\mathrm{X}_{\mathrm{CO} 2} \frac{\mathrm{MW}_{\mathrm{CO}_{2}}}{\mathrm{MW}_{\text {wet mix }}}\left(1-2 \frac{\dot{\mathrm{m}}_{\mathrm{CH}_{4}}}{\dot{\mathrm{m}}_{\text {tot }}} \frac{\mathrm{MW}_{\text {wet mix }}}{\mathrm{MW}_{\mathrm{CH}_{4}}}\right)
$$

Substitution of Eqns. C.4, C.14, and C.15 into the overall carbon balance Eqn. C.3 and simplifying gives

$$
\begin{aligned}
& \frac{\dot{\mathrm{m}}_{\mathrm{CH}_{4}}}{\mathrm{MW}_{\mathrm{CH}_{4}}}+\mathrm{Y}_{\mathrm{CO}_{2}, \infty} \frac{\dot{\mathbf{m}}_{\text {air }}}{\mathrm{MW} \mathrm{WO}_{\mathrm{CO}_{2}}} \\
& =\frac{\dot{\mathbf{m}}_{\mathrm{tot}}}{\mathrm{MW}_{\text {wet mix }}}\left(1-2 \frac{\dot{\mathbf{m}}_{\mathrm{CH} 4}}{\dot{\mathbf{m}}_{\text {tot }}} \frac{\mathrm{MW}_{\text {wet mix }}}{\mathrm{MW}_{\mathrm{CH}_{4}}}\right)\left[\mathrm{X}_{\mathrm{CO}_{2}}+\mathrm{X}_{\mathrm{Co}}\right]
\end{aligned}
$$

Solving Eqn. C. 16 for the term in parenthesis and substituting this term into Eqn. C.14 for the mass fraction of $\mathrm{CO}$ in the exhaust steam yields

$$
\mathbf{Y}_{\mathrm{CO}}=\mathbf{X}_{\mathrm{CO}} \mathbf{M W} \mathrm{Co}\left[\frac{\frac{\dot{\mathbf{m}}_{\mathrm{CH}_{4}}}{\mathbf{M} \mathbf{W}_{\mathrm{CH}_{4}}}+\mathbf{X}_{\mathrm{CO} 2, \infty} \frac{\dot{\mathbf{m}}_{\mathrm{air}}}{\mathbf{M W}_{\mathrm{air}}}}{\dot{\mathrm{m}}_{\mathrm{tot}}\left(\mathbf{X}_{\mathrm{CO} 2}+\mathbf{X}_{\mathrm{co}}\right)}\right]
$$

Substitution of Eqn. C.17 into the definition of the CO emission index, Eqn. C.1, and simplifying yields

$$
\mathrm{EI}_{\mathrm{CO}}=\frac{\mathbf{X}_{\mathrm{CO}}}{\mathbf{X}_{\mathrm{CO}_{2}}+\mathbf{X}_{\mathrm{CO}}}\left[\frac{\mathbf{M W}_{\mathrm{CO}}}{\mathbf{M W} \mathbf{C H}_{4}}+\frac{\dot{m}_{\mathrm{air}}}{\dot{\mathbf{m}}_{\mathrm{CH} 4}} \frac{\mathbf{M W}_{\mathrm{CO}}}{\mathbf{M W}_{\mathrm{air}}} \mathbf{X}_{\mathrm{CO}_{2}, \infty}\right]
$$


In a similar manner, we can define the $\mathrm{NO}_{\mathrm{x}}$ emission index as

$$
\mathrm{EI}_{\mathrm{NOx}} \equiv \frac{\dot{\mathbf{m}}_{\mathrm{tot}}}{\dot{\mathbf{m}}_{\mathrm{CH} 4}} \mathbf{Y}_{\mathrm{NO}}
$$

If we apply conservation of species and mass principles as before, we ultimately attain the final form of the $\mathrm{NO}_{\mathrm{X}}$ emission index,

$$
\mathrm{EI}_{\mathrm{NOx}}=\frac{\mathbf{X}_{\mathrm{NOx}}}{\mathbf{X}_{\mathrm{CO} 2}+\mathbf{X}_{\mathrm{CO}}}\left[\frac{\mathbf{M W}_{\mathrm{NOx}}}{\mathbf{M W}_{\mathrm{CH} 4}}+\frac{\dot{\mathbf{m}}_{\mathrm{air}}}{\dot{\mathrm{m}}_{\mathrm{CH}_{4}}} \frac{\mathbf{M W}_{\mathrm{NOx}}}{\mathbf{M W}_{\mathrm{air}}} \mathbf{X}_{\mathrm{CO}_{2}, \infty}\right]
$$

In the laminar jet diffusion flames presented in this work, the ambient carbon dioxide mole fraction, $\mathbf{X}_{\mathrm{CO}_{2} \infty}$, and the carbon monoxide mole fraction, $\mathbf{X}_{\mathrm{co}}$, were negligible. Thus, cancellation of these terms in the $\mathrm{CO}$ and $\mathrm{NO}_{\mathrm{x}}$ emission index Eqns. C.18 and C.20 yields the final form of the emission indices used in this report:

$$
\mathbf{E I}_{\mathrm{CO}}=\frac{\mathbf{X}_{\mathrm{CO}}}{\mathbf{X}_{\mathrm{CO} 2}} \frac{\mathbf{M W}_{\mathrm{CO}}}{\mathbf{M W}_{\mathrm{CH} 4}}
$$

and,

$$
\mathrm{EI}_{\mathrm{NOx}}=\frac{\mathrm{X}_{\mathrm{NOx}}}{\mathrm{X}_{\mathrm{CO}_{2}}} \frac{\mathrm{MW}_{\mathrm{NOx}}}{\mathrm{MW}_{\mathrm{CH}_{4}}} .
$$

